\title{
REGULACIÓN DE LAS ENZIMAS DESATURANTES EN LA DIABETES MELLITUS EXPERIMENTAL
}

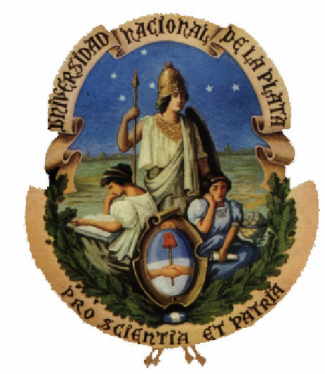

Tesis Doctoral

Universidad Nacional de La Plata

Facultad de Ciencias Exactas

Departamento de Ciencias Biológicas

2007

Tesista: Bioquímico Mauro A. Montanaro

Director: Dr. Rodolfo R. Brenner

Co-Director: Dr. Omar J. Rimoldi 
El presente trabajo de tesis, para optar al grado de Doctor de la Facultad de Ciencias Exactas, fue realizado en el Instituto de Investigaciones Bioquímicas de La Plata (INIBIOLP), Facultad de Ciencias Médicas, UNLP, bajo la dirección del Dr. Rodolfo R. Brenner y la codirección del Dr. Omar J. Rimoldi. 
a mi hija Lola que está a punto de llegar a este mundo, a Moni y mis hermanas y muy especialmente a mis padres, que tanto esfuerzo hicieron por mi 


\section{$\underline{\text { Mi reconocimiento }}$}

al Instituto de Investigaciones Bioquímicas de La Plata, en la persona de su anterior Director, Dr. Rodolfo R. Brenner y de su actual Directora Dra. María J. Tacconi de Alaniz, por haberme dado la oportunidad de realizar este trabajo en el INIBIOLP.

a la Facultad de Ciencias Exactas de la UNLP y a todos sus profesores por haberme enseñado tanto

a la Agencia Nacional de Promoción Científica y Tecnológica y al Consejo Nacional de Investigaciones Científicas y Técnicas, por las becas que me brindaron y por los subsidios otorgados a nuestro grupo de trabajo. 


\section{Mi agradecimiento:}

al Dr. Rodolfo Brenner y al Dr. Omar Rimoldi, quienes han tratado, infructuosamente, que yo aprenda algo.

a la más grande de todas, a la que a veces fue mi amiga y a veces mi madre, Susana González, y a su inseparable amiga Ana Bernasconi. Ambas hicieron gran parte de este trabajo.

a mis compañeras del laboratorio 11, Gabriela y Soledad, quienes me soportan todos los días.

a mis amigos del Altillo, Nicolás Tati, Claudia, Jole y Magalí, que día a día escuchan atentamente las pavadas que digo sin quejarse tanto.

a mis compañeros de los laboratorios 12 y 8 bis, a quienes adeudo kilos de yerba.

al Dr. Goya, a Yolanda y a los demás integrantes del laboratorio por su invalorable ayuda en el manejo de animales. 
a mis compañeros de los laboratorios 7,3 y de "radioisótopos", en donde hago mis recreos y a veces hablamos en serio.

a los integrantes del CIC, por toda su colaboración.

a mis amigos Charly y Juan, con los que he compartido algunas horas de trabajo y muchas de asados

a todos los integrantes del INIBIOLP, en donde encontré muchos más amigos que compañeros de trabajo. 


\section{$\underline{\text { Índice de contenidos }}$}

Página

\section{Introducción}

I.A Generalidades 1

I.B Biosintesis de ácidos grasos 4

$\begin{array}{ll}\text { I.C Desaturasas de ácidos grasos } & 7\end{array}$

.1 Estearoil-CoA Desaturasa 9

$.2 \Delta 6$ y $\Delta 5$ Desaturasas $\quad 16$

.3 Regulación de las Desaturasas $\quad 21$

.4 Desaturasas y Diabetes Mellitus 34

I.D Objetivos 38

\section{Metodologia}

II.A Modelos animales, dietas y tratamientos 39

.1 Animales 39

.2 Tratamientos realizados para obtener modelos diabéticos $\quad 40$

.3 Tratamiento con insulina 42

.4 Tratamientos con agonistas de factores de transcripción $\quad 42$

II.B Medida de parámetros plasmáticos $\quad 44$

II.C Obtención de fracciones subcelulares y análisis de lípidos $\quad 46$

.1 Fraccionamiento subcelular hepático 46

.2 Composición de ácidos grasos $\quad 47$

II.D Medida de actividades enzimáticas 50

.1 Actividad desaturante de AG en

microsomas hepáticos $\quad 50$

.2 Acil-CoA oxidasa peroxisomal hepática 51 
.3 Palmitoil CoA elongasa microsomal hepática 52

II.E Protocolos generales de trabajo con ADN 54

.1 Transformación de bacterias con plásmidos de interés

.2 Obtención de plásmidos en pequeña escala

.3 Digestión con enzimas de restricción $\quad 57$

.4 Electroforesis sumergida en geles de agarosa

.5 Aislamiento de fragmentos de ADN $\quad 58$

.6 Reacción de ligación

.7 Obtención de plásmidos en gran escala 60 .8 Amplificación de ADN mediante PCR 60 II.F Determinación de proteínas

por Western blot

.1 Anticuerpos anti-ACD-1 y anti- $\Delta 6$

desaturasa

.2 Ensayo de Western blot

II.G Medida de ARNm de desaturasas hepáticas mediante Northern blot

II.H Análisis estadístico

\section{Resultados}

III.A Efectos de insulina y fenofibrato sobre animales diabéticos de tipo I

III.B Efectos de insulina, fenofibrato y T091317

sobre animales diabéticos de tipo I

III.C Ratas SAC (modelo de Diabetes Mellitus tipo II inducida por dieta) 
III.D Ratas eSS (modelo de Diabetes Mellitus tipo II)

IV. Discusión y conclusiones

IV.A Interacción entre tratamientos con insulina y fenofibrato sobre animales diabéticos de tipo I

IV.B Análisis de las interacciones combinadas

entre Insulina, T091317 y Fenofibrato

113

IV.C Ratas SAC

121

IV.D Ratas eSS

126

IV.E Conclusiones

130 
AA

ACAT

$\mathrm{ACC}$

ACP

ADG

AG

AMPK

CE

ChoRE

DCF

DGAT

DHA

DMSO

EPA

Fen

FL

LB

L-FABP

LXR

MUFAs

PAGE

PC

PPAR

PPRE

PUFAs

RXR

SCD

SRE

SREBP

STZ

T09

TG

VLDL ácido araquidónico

acil-CoA colesterol aciltransferasa

acetil-CoA carboxilasa

proteínas transportadores de acilos

alquil-2,3-diacilglicerol

ácido grasos

proteína quinasa activada por AMP

ésteres de colesterol

carbohidrate response element

diclorofluoresceína

diacilglicerol aciltransferasa

ácido docosahexenoico

dimetilsulfóxido

ácido eicosapentenoico

fenofibrato

fosfolipidos

medio de crecimiento de Luria-Bertani

liver fatty acid binding protein

liver $X$ receptor

ácidos grasos monoinsaturados

electroforesis en gel de poliacrilamida

fosfatidilcolina

peroxisome proliferator activated receptor

peroxisome proliferator response element

ácidos grasos poliinsaturados

retinoic $X$ receptor

estearoil-CoA desaturasa

sterol regulatory element

sterol regulatory element binding protein

estreptozotocina

T091317

triglicéridos

lipoproteína de muy baja densidad 


\section{I - INTRODUCCIÓN}

\section{I.A GENERALIDADES}

Debido al cambio en los hábitos alimenticios y a la adopción de un estilo de vida más sedentario de las últimas décadas, los desórdenes metabólicos relacionados con los lípidos y en particular con los ácidos grasos, tales como la obesidad, han causado un gran impacto. A su vez, la obesidad aumenta el riesgo de padecimiento de enfermedades crónicas como diabetes, resistencia a la insulina, hipertensión, enfermedad cardiovascular, enfermedad de hígado graso, las cuales han sido denominadas colectivamente como síndrome metabólico (Reaven, GM, 2005; Reaven, GM, 2004). Gracias al mejor entendimiento que se tiene acerca de las rutas bioquímicas y de los mecanismos moleculares en general, se hace cada vez más evidente que las propiedades de los ácidos grasos no se limitan solamente a las estructurales y a las relacionadas con las reservas energéticas, sino que se los ha asimilado como moduladores finos del metabolismo y de diferentes mecanismos de señalización celular.

La primera y más obvia función que se le conoce a los ácidos grasos, como resultado de su alta densidad energética y de sus propiedades hidrofóbicas, es la de representar un reservorio para la energía metabólica en exceso. Como componentes de glicerolípidos y de ésteres de colesterol, son esenciales para el funcionamiento apropiado 
de las membranas biológicas. La incorporación de ácidos grasos monoinsaturados (MUFAs) y poliinsaturados (PUFAs) a los glicerolipidos de membrana disminuye su temperatura de transición de fase sólidagel a liquida-cristalina, y le otorga a la membrana la fluidez necesaria para su correcto funcionamiento (Mouritsen, OG y Jorgensen, K, 1992), como así también para el de las proteínas ancladas a ella. Los MUFAs también ejercen su influencia sobre procesos de apoptosis (Parthasaraty, S y col. 1990) y a su vez podrian tener algunos roles en la mutagénesis de ciertos tumores (Kim, JH y col., 1999). Por su parte, el ácido oleico es el ácido graso preferido como sustrato de la acil-CoA colesterol aciltransferasa (ACAT) y de la diacilglicerol aciltransferasa (DGAT) (Cases, S y col., 1998 a y b; 2001) lo cual lo coloca como actor principal en la sintesis hepática de triglicéridos (TG) y ésteres de colesterol (CE), y lo transforma en vital para el ensamblaje y la secreción de lipoproteínas de muy baja densidad (VLDL) en el hígado (Landau, JM y col., 1997; Miyazaki, M y col., 2000).

Además, tanto los MUFAs como los PUFAs, participan en una variedad de procesos fisiológicos como el mantenimiento de la integridad de la piel, en la visión y en el funcionamiento del sistema nervioso central (Nakamura, MT y Nara, TY, 2003), y sirven como precursores para un gran número de moléculas biológicamente activas, como eicosanoides, factores de regulación del crecimiento y hormonas. En los mamíferos, los eicosanoides como las prostaglandinas, leucotrienos y tromboxanos actúan localmente a través de procesos autocrinos o paracrinos sobre receptores de superficie celular ligados a proteínas $\mathrm{G}$, conduciendo a la activación de diferentes cascadas de señalización que tienen efecto sobre numerosas funciones celulares que incluyen quimiotaxis, permeabilidad vascular, inflamación, vasoconstricción, (Jump, DB, 2002) y regulación de la homeostasis 
(Sprecher, H, 1981). Adicionalmente, actuando en forma de segundos mensajeros, los PUFAs gobiernan la expresión de un gran número de genes especialmente involucrados en el metabolismo de los lípidos, pero también la de otros que codifican para transportadores, proteínas de unión (binding proteins) y para otros factores involucrados en termogénesis y diferenciación celular (Clarke, SD y Jump DB, 1994; 1997; de Urquiza, A M y col., 2000).

Las fallas en la modulación de la biosíntesis de PUFAs son un blanco de importancia en el tratamiento de ciertas enfermedades crónicas como diabetes mellitus tipo I y II, artritis, inflamación, cáncer, enfermedad cardiovascular y obesidad (Miyazaki, M y Ntambi JM, 2003). También se ha encontrado alterado el contenido tisular de PUFAs en situaciones patológicas como desórdenes peroxisomales, exceso de hormona de crecimiento y alcoholismo (Nakamura, MT y Nara, TY, 2003). 


\section{I.B BIOSÍNTESIS DE ÁCIDOS GRASOS INSATURADOS}

Los ácidos grasos insaturados se sintetizan a partir de ácidos grasos más cortos y menos insaturados utilizando un sistema enzimático que introduce una serie de desaturaciones y elongaciones sucesivas (llevado a cabo por desaturasas y elongasas), alcanzando una extensión y un grado de desaturación que dependen de la especie y del tejido en donde nos situemos. Estas diferencias inter-especie producen la aparición del concepto de esencialidad, lo que significa que determinados seres vivos deben incorporar con la dieta ciertos ácidos grasos que son esenciales para su supervivencia, provenientes de otras especies, debido a su incapacidad de sintetizarlos de novo.

En la Fig. I.1 se resumen los pasos metabólicos que conducen a la biosíntesis de PUFAs de cadena larga (a partir de 16 átomos de carbono) en mamíferos, y se adjunta un esquema de lo que ocurre en plantas superiores, en donde normalmente se encuentra solo una limitada capacidad para la sintesis de $\mathrm{C}_{20+}$ PUFAs (PUFAs con más de 20 átomos de carbono) (Napier, JA y col, 2003; Brenner, RR, 2003).

En los mamíferos, todos los PUFAs que se sintetizan derivan del ácido palmítico (16:0) dietario y sintetizado de novo, y de los ácidos grasos esenciales provenientes de la dieta. Debido a diferencias en los niveles de expresión enzimática entre los distintos tejidos, existen diferencias en cuanto a las composiciones de ácidos grasos en diferentes órganos. Uno de los productos más importantes de esta ruta es el ácido docosahexenoico (DHA, 22:6n-3). Este ácido graso posee importantes roles en el funcionamiento de las células fotorreceptoras y en el cerebro, lugares en donde su concentración se halla relativamente elevada. Hasta el año 1991, se postulaba la existencia de una $\Delta 4$ desaturasa involucrada en su sintesis, pero a partir de los trabajos del grupo de Sprecher y col (Voss, A y col., 1991; Sprecher, H y col., 1995) 
se llegó a la idea actual acerca de la participación de la $\beta$-oxidación peroxisomal en su ruta biosintética.

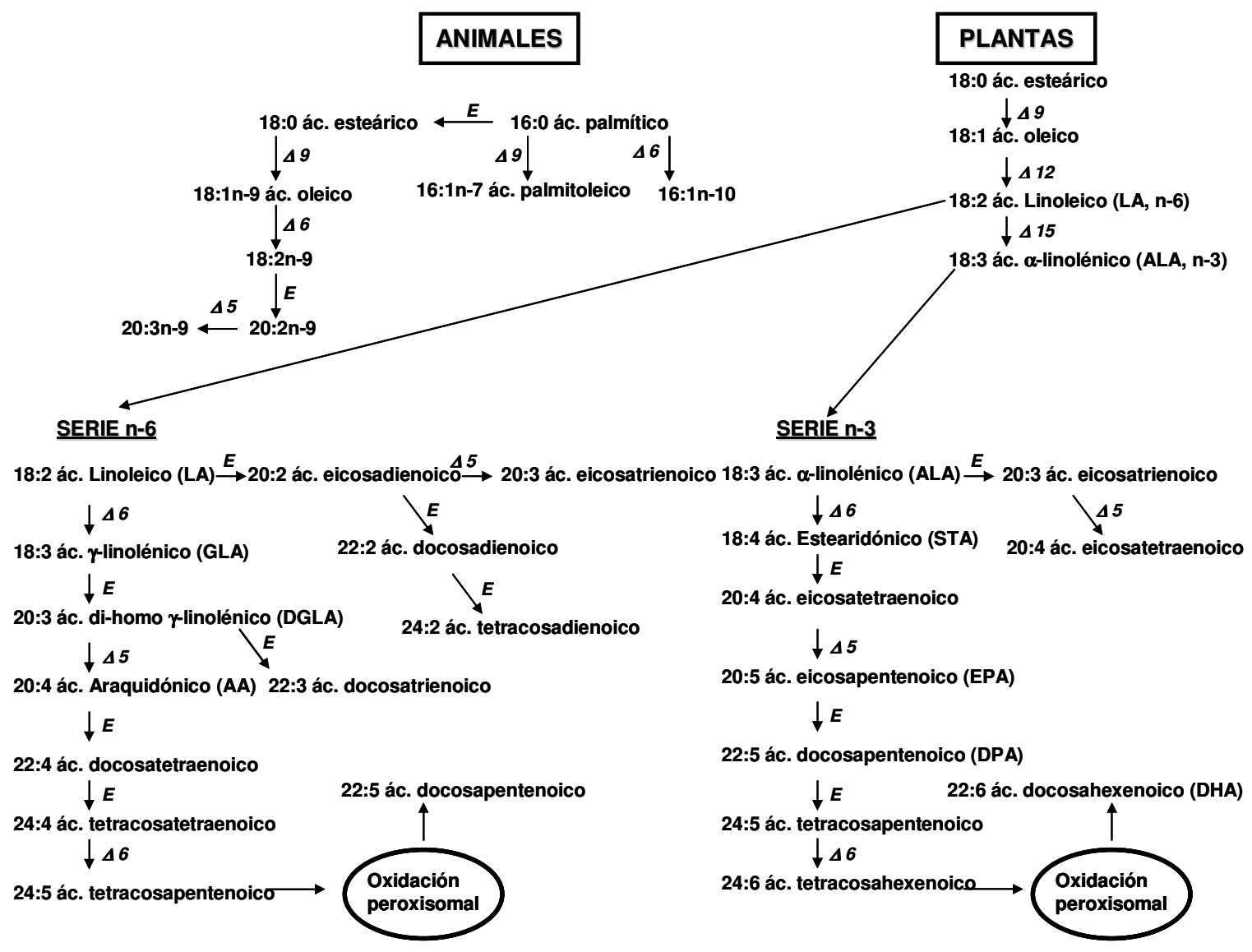

Fig. I. 1 Principales pasos metabólicos que conducen a la síntesis de PUFAs en animales. Estos carecen de actividad $\Delta 12$ y $\Delta 15$ desaturasa, por lo que deben incorporar LA y ALA con la dieta. $\Delta 5, \Delta 6$ y $\Delta 9$ : desaturaciones en posiciones 5,6 y 9 respectivamente; E: elongaciones.

Los PUFAs superiores de la serie n-3 (con la última insaturación a 3 carbonos del extremo metilénico), especialmente 20:5 y 22:6, se pueden obtener también directamente de la dieta, preferentemente por ejemplo a partir de peces con alto contenido de grasa y de mamíferos marinos. Mientras tanto, las comidas a base de carne y de aceites vegetales aportan una buena parte de los ácidos grasos de la serie n-6. Así, los PUFAs n-3 y n-6 confieren varios beneficios a la salud, entre los que se pueden mencionar el incremento de la señalización insulínica, 
potenciación de la respuesta inmune, disminución de los lípidos plasmáticos, disminución de la incidencia de enfermedad pulmonar y coronaria, incluso se los ha encontrados como beneficiosos en ciertos tipos de cáncer como de mama, de próstata y colorectal, entre otros efectos favorables (Sampath, H y Ntambi, JM, 2005). 


\section{I.C DESATURASAS DE ÁCIDOS GRASOS}

A pesar de que el término desaturasa incluye a todas las enzimas capaces de activar al oxígeno y usarlo para la modificación subsiguiente de enlaces $\mathrm{C}-\mathrm{H}$ en grupos de sustratos tan diferentes como grupos alquilo, residuos acilo de enlaces tio-, amida-, y oxígeno-éster, carotenoides, esfingolípidos, aldehídos y esteroles, el presente trabajo se focaliza en el estudio de las desaturasas de ácidos grasos.

En base a la comparación de las secuencias de sus genes, podemos encontrar tres grandes grupos de desaturasas de ácidos grasos. Las acil-ACP desaturasas se encuentran en plantas (ubicadas exclusivamente en plástidos), son de forma soluble y son capaces de desaturar ácidos grasos ligados a acyl carrier proteins (ACP). En los dos grupos restantes encontramos enzimas ligadas a membrana, y aparecen, en primer lugar, las acil-lipido desaturasas, pueden desaturar ácidos grasos ligados a lípidos y que se pueden encontrar en plantas, hongos y cianobacterias. Por último, aparecen las enzimas a las que nos referiremos de aquí en adelante, las acil-CoA desaturasas de ácidos grasos de animales, también presentes en levaduras y hongos. Estas enzimas actúan sobre sus sustratos unidos a coenzima A.

En animales, las velocidades de elongación son mayores a las de desaturación, por lo que es un hecho aceptado que la regulación de la biosintesis de PUFAs está llevada a cabo principalmente a nivel de las desaturasas de ácidos grasos, las que determinan la velocidad de sintesis y contribuyen a regular el nivel celular de PUFAs, y por lo tanto se hallan fuertemente reguladas.

Más recientemente, ha cobrado cierta importancia el estudio de la regulación de las enzimas elongasas. Tanto en humano como en rata y ratón existen 7 elongasas (Elovl-1 a Elovl-7). Elovl1 y 6 elongan ácidos 
grasos saturados y monoinsaturados, mientras que entre los sustratos de Elovl-2 se incluye a PUFAs de 20-22 átomos de carbono. Elovl-5 es capaz de alongar un amplio rango de sustratos (entre 16 y 22 átomos de carbono). Por su parte, Elovl-3 y 4 se expresan en piel y retina, respectivamente, siendo capaz actuar sobre PUFAs de hasta 26 átomos de carbono. En hígado de rata, solo se expresan Elovl-5, 1, 2 y 6, siendo la primera de ellas la más abundante y la que más varía en función de las condiciones nutricionales y de desarrollo del animal, estando ejercida esta regulación principalmente a través de PPARa y SREBP-1c (Wang, Y y col., 2006).

Los mamíferos poseen $\Delta 9$ desaturasa (o estearoil-CoA desaturasa, $\mathrm{SCD})$, junto con $\Delta 6$ y $\Delta 5$ desaturasas. Estas enzimas son específicas en cuanto a la localización, número y estereoquímica de los dobles enlaces previamente presentes en sus sustratos (Sperling, P y col., 1993). Por lo tanto, solamente tienen la capacidad de producir insaturaciones en las posiciones \#9 (entre carbonos 9 y 10), \#6 y \#5, respectivamente, dentro de la cadena hidrocarbonada de sus sustratos, en los cuales la numeración de los carbonos se toma desde el grupo carboxilo.

A su vez, también existen diferencias dentro de las distintas especies animales, por ejemplo, los gatos parecen expresar bajos niveles relativos de $\Delta 6$ y posiblemente de $\Delta 5$ desaturasas (Rivers, JP y col, 1975), algunos peces marinos muestran $\Delta 6$ desaturasas funcionales pero actividad $\Delta 5$ limitada (Mourente, G y Tocher, DR, 1994), mientras que en otros peces de aguas frías se encuentran altas actividades para ambas enzimas, con elevadas concentraciones relativas de ácidos araquidónico (AA), eicosapentenoico (EPA) y docosahexenoico (DHA) (Henderson, RJ, 1996).

Hay además una serie de excepciones al esquema general presentado en la Fig. I.1. Existen algunos invertebrados que exhiben 
actividad $\Delta 12$ desaturasa, como Periplaneta americana y Caenorhabditis elegans, mientras que algunos también son capaces de expresar actividad $\Delta 15 / \omega 3$ desaturasa (C. elegans). Recientemente, se ha caracterizado la presencia de un gen que expresa una enzima $\Delta 5 / \Delta 6$ bifuncional en zebrafish (Danio rerio). Finalmente se puede también mencionar, en algunos organismos eucariotas inferiores, una ruta alternativa para la sintesis de AA utilizando una $\Delta 8$ desaturasa, como en Euglena gracilis, y en Tetrahymena, como asimismo la existencia una $\Delta 4$ desaturasa identificada recientemente en el alga Thraustochytrium para la producción de DHA a partir de DPA (Pereira, SL y col., 2003).

\section{I.C.1 Estearoil-CoA Desaturasa}

\section{a) Caracteristicas generales}

La SCD, es una proteína de aproximadamente $42 \mathrm{kDa}$ que cataliza la producción de la primera desaturación en la ruta que continúa hacia a sintesis de PUFAs, pudiendo actuar sobre una variedad de sustratos, pero con elevada selectividad hacia la catálisis de 16:0 a 16:1 y de 18:0 a 18:1n-9, haciéndolo en modo cis y en la posición \#9. Esto la convierte también en la enzima limitante de la velocidad de la síntesis de los MUFAs. Esta proteína está ligada a la membrana del retículo endoplasmático y funciona en forma de complejo junto con un citocromo b5 y con una flavoproteína citocromo b5 reductasa dependiente de $\mathrm{NADH}$ (Fig. I.2). Este último provee los equivalentes reductores para la reacción, los que pasan al transportador de electrones (y portador de un grupo hemo) citocromo b5 a través de la proteína citocromo b5 reductasa, para finalmente producir la desaturación del ácido graso sustrato a través del centro diférrico de la SCD (Enoch, HG y col., 1976). La reacción también 
requiere oxígeno molecular, el cual no se incorpora al acil graso, sino que, luego de recibir los electrones provenientes de las oxidaciones del NADH y del acil-CoA, se libera en forma de agua (Jones, PD y col., 1969).

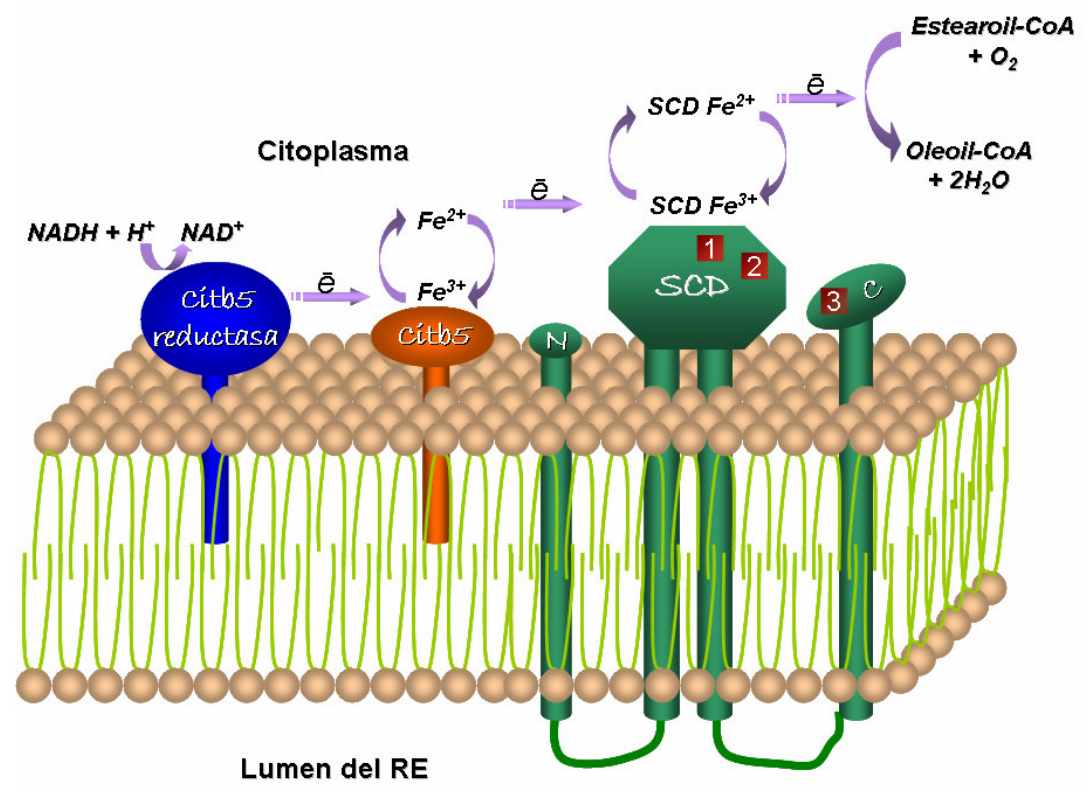

Fig. I. 2 Esquema de la reacción de desaturación y de la disposición de la SCD en la membrana del retículo endoplasmático (RE). Los cuadros rojos representan a los motivos de cajas de histidina.

El mecanismo enzimático es altamente específico con respecto a la posición del doble enlace, en donde la SCD elimina los átomos de hidrógeno comenzando por la posición \#9, y luego haciendo lo mismo con el segundo hidrógeno, ahora en la posición \#10 de la cadena (Behrouzian, B y col., 2002).

La secuencia de aminoácidos de la SCD muestra tres segmentos ricos en histidina, llamados motivos cajas de histidina (histidine boxes), ( $\mathrm{HxxxxH}, \mathrm{HxxHH}$ y $\mathrm{HxxHH})$, en donde se encuentran estos residuos de histidina esenciales para la catálisis, lo cual ha sido demostrado a partir de experimentos de mutagénesis dirigida (Stukey, JE y col., 1990). Estos tres segmentos, comenzando en los residuos 119, 156 y 
296, son los que proveen los ligandos para los iones férricos del sitio catalítico. A pesar de que el modelo actual, que parte de un análisis de hidrofobicidad de residuos de aminoácidos llevado a cabo con la SCD1 de rata y de levadura, todavía no se encuentra del todo esclarecido, supone que la proteína posee cuatro segmentos que atraviesan la membrana del RE, quedando la parte media de la misma, así como sus extremos N-terminal y C-terminal, del lado citosólico. Más recientemente, se ha confirmado bastante bien este modelo para la SCD1 de ratón, junto con el dato de que los residuos de Cys de la proteína no son esenciales para su actividad catalítica (Man, WC y col., 2006).

\section{b) Isoenzimas}

Hasta la fecha se han podido identificar, clonar y caracterizar genes SCD de diferentes especies como C. elegans, hamster, oveja, rata, ratón y humano. Se han podido diferenciar dos isoformas de SCD en rata (rSCD1 y rSCD2) (Mihara, K, 1990), así como 4 isoformas en ratón (mSCD1 a 4) (Kaestner, KH y col., 1989; Ntambi, JM y col., 1988; Zheng, Y y col., 2001; Miyazaki, M y col., 2003a) y dos isoformas en humanos (hSCD1 y hSCD5) (Zhang, L y col., 1999; Wang, J y col., 2005).

La rSCD1 se expresa constitutivamente en riñón, pulmón, corazón y bazo y en tejido adiposo. En el hígado puede variar mucho su expresión en respuesta a señales activadoras que se discutirán más adelante. Mientras tanto, el ARNm de rSCD2 se halla ausente en el hígado en condiciones de dieta normal, expresándose constitutivamente en cerebro, y con la posibilidad de inducir su expresión bajo determinadas condiciones en tejidos como el adiposo, renal y pulmonar (Mihara, K, 1990). 
En el caso del ratón, las cuatro isoformas, cuyas secuencias codificantes se ubican en el cromosoma 19, poseen características de actividad desaturante bastante similares, tanto para estearoil-CoA como para palmitoil-CoA, pero muestran diferentes perfiles de distribución tisular. Mientras que mSCD1 se expresa principalmente en tejidos lipogénicos como tejido adiposo, hígado, glándula prepucial y glándulas sebáceas, mSCD2 se encuentra distribuida más homogéneamente, presentándose especialmente en cerebro, pulmones y testículos. mSCD3 se limita solamente a glándulas sebáceas de la piel y a las prepuciales (Miyazaki, M y col., 2005). La recientemente identificada isoforma mSCD4 parece ser específica de corazón (Miyazaki, M y col., 2003a). Por el lado del humano, utilizando RT-PCR y en coincidencia con su ortólogo de ratón, se demostró la presencia del ARNm de hSCD1 (cromosoma 10) en varios tejidos adultos, con una preponderancia en tejido adiposo e hepático. A su vez, lo mayores niveles de ARNm de hSCD5 (cromosoma 4) se encontraron en cerebro y páncreas, en donde alcanzó niveles comparables a los de hSCD1 en adultos, y mayores a los de hSCD1 en el caso del hígado fetal.

Cuando se comparan las secuencias aminoacidicas predichas para todos los genes SCD nombrados anteriormente, se encuentra que las mismas poseen una identidad de entre $79-87 \%$, salvo para el caso de hSCD5, cuya identidad con cada una de las demás desaturasas varía entre 54-58\%. Cuando se consideran los aminoácidos conservados, la similitud entre todas las isoformas se ubica en el rango de 91-98\%, menos para hSCD5, para la cual este rango es de $72-74 \%$ solamente. Debido a estas diferencias con el resto, se encontró que hSCD5 no posee ningún ortólogo en ratón ni en rata, por lo que debió denominarse con esa numeración (Wang, J y col., 2005). 
Aparentemente, las diferentes SCDs han ido apareciendo durante el transcurso de la evolución a través de eventos de duplicación génica recientes (como en el caso de las mSCDs) o ancestrales (como hSCD5) La razón por la cual en algunas especies se encuentra más de una isoforma de esta enzima no es del todo conocida, pero se supone que este hecho tiene que estar relacionado con diferencias en la especificidad de sustrato así como con su regulación diferencial a través de factores de transcripción tejido específicos. Por ejemplo en ratón, mientras que 16:0-CoA es el principal sustrato para la SCD3, la SCD1 y la SCD2 utilizan preferencialmente a 18:0-CoA (Ntambi, JM y Miyazaki, M, 2004).

\section{c) Rol en el metabolismo}

Debido a que los principales productos de la SCD (16:1 y 18:1n-9) son a su vez los MUFAs mayoritarios en varios tipos de lipidos, como fosfolipidos, triacilglicéridos, ésteres de colesterol, ceras esterificadas, y debido a los múltiples roles ya mencionados anteriormente que los mismos cumplen de manera independiente, es de esperar que las variaciones en la actividad de SCD de los mamíferos tengan efecto sobre una amplia variedad rutas metabólicas y de procesos patológicos.

El rol más inmediato que surge a partir de su actividad es el regulador de la fluidez de las membranas biológicas a partir de su participación en la regulación del nivel de MUFAs y por lo tanto del nivel de incorporación de los mismos en glicerolipidos y ésteres de colesterol.

Algo sorprendente es el hecho de que a pesar de que el 18:1n-9, uno de sus productos, es uno de los ácidos grasos más abundantes en la dieta, por lo que su provisión está casi asegurada, la SCD está altamente regulada. En nuestro laboratorio se demostró, a partir de la administración de dieta deficiente en ácidos grasos esenciales y con alto 
contenido de colesterol, que el nivel de ésteres de colesterol (ésteres de palmitoleoilo y oleoilo) se eleva rápidamente en paralelo con la activación trascripcional de la SCD1, acompañado por una depresión en los niveles de $\Delta 5$ y $\Delta 6$ desaturasas (Brenner, RR y col., 2002). Además, a partir de modelos murinos que presentan mutaciones en el gen de SCD1 (cepas de ratones asebia) o modelos murinos SCD-/- (Miyazaki, M y col., 2001), se ha llegado a comprender que los productos sintetizados endógenamente por la SCD sirven como principal fuente de sustratos para la síntesis de TG y CE hepáticos. Debido a que la ACAT y la DGAT están localizadas en el ER, probablemente se requiera una alta expresión de SCD para una mayor accesibilidad de MUFAs en la vecindad de estas enzimas. Todos estos resultados demuestran que la SCD1 es de vital importancia para la síntesis de la lipoproteína VLDL y para la exportación de lípidos hepáticos, así como para la regulación de los niveles de TG plasmáticos. Por la misma razón, esta enzima es un blanco potencial para el tratamiento de síndromes hipertrigliceridémicos en humanos.

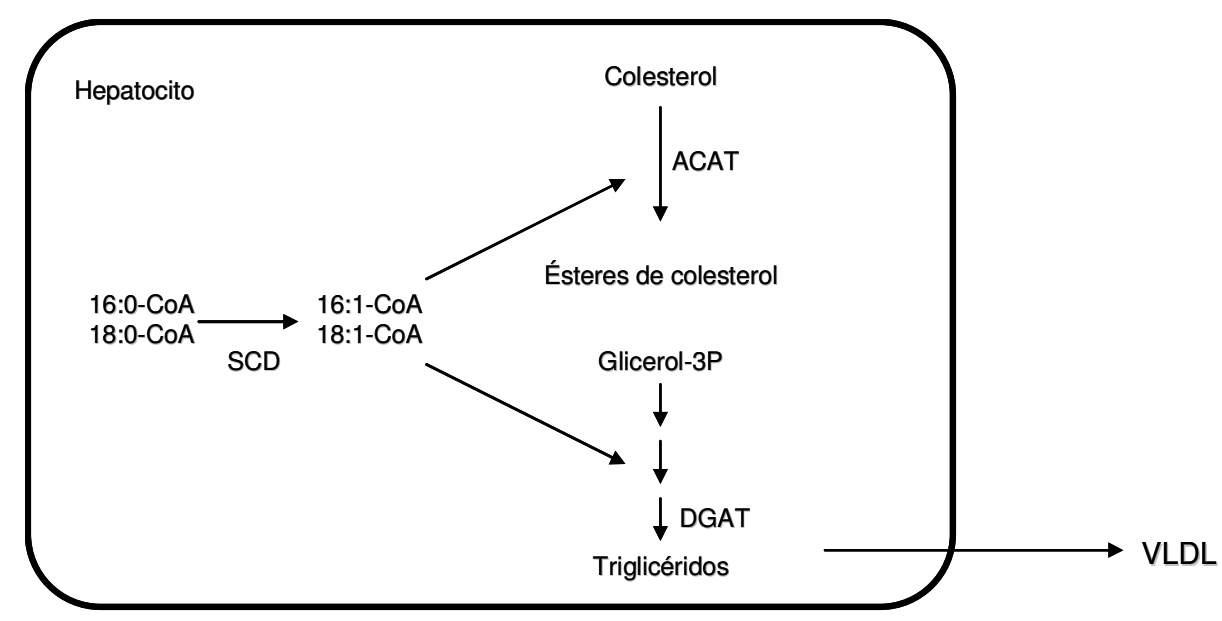

Fig. I. 3 Rol de la SCD en la sintesis de CE, TG y en la secreción de VLDL.

En estos mismos modelos se ha encontrado también un importante rol de la SCD en el funcionamiento de las glándulas 
sebáceas de la piel y en las de Meibomio del ojo, en donde participa en la sintesis de TG, CE y ceras esterificadas, así como también en la protección celular frente a la acumulación de colesterol. Además, en animales, esta enzima posee un rol en la síntesis de otra clase de lípido, el alquil-2,3-diacilglicerol (ADG), el cual es secretado por las glándulas de Harder del tercer párpado y cumple funciones de lubricación para facilitar el desplazamiento del mismo.

A través del estudio del fenotipo de ratones SCD1-/-, se ha encontrado que los mismos poseen adiposidad corporal reducida, incrementada sensibilidad a la insulina y que son resistentes a la ganancia de peso inducida por la dieta (Miyazaki, M y col., 2001). La deficiencia de esta enzima aparentemente induce de alguna forma las vías dependientes de peroxisome proliferator activated receptor-a (PPARa), conduciendo a un aumento de la oxidación a ácidos grasos a la vez que desactiva la expresión de sterol regulatory element binding protein-1 (SREBP-1) conduciendo a una disminución de la sintesis lipídica. Este modelo presenta un incremento en la concentración de ácidos grasos saturados (16:0 y 18:0) mientras que el contenido de PUFAs se encuentra normal. El aumento de los primeros podría activar directamente al PPAR-a, alternativamente este aumento podría inhibir a la acetil-CoA carboxilasa (ACC), entre otras enzimas, (Cohen, P y col., 2002), disminuyendo el nivel de malonil-CoA, lo que produciría la disminución de la síntesis de ácidos grasos y lipidos en general. Además, la modificación en los niveles de los ácidos grasos conduciría a una activación de la proteína quinasa activada por AMP (AMPK), lo que a través de la des-represión de CPT-1, al igual que con la disminución del malonil-CoA, activaría la oxidación de ácidos grasos (ver Fig. I-4). (Sampath, H y Ntambi, JM, 2006). 


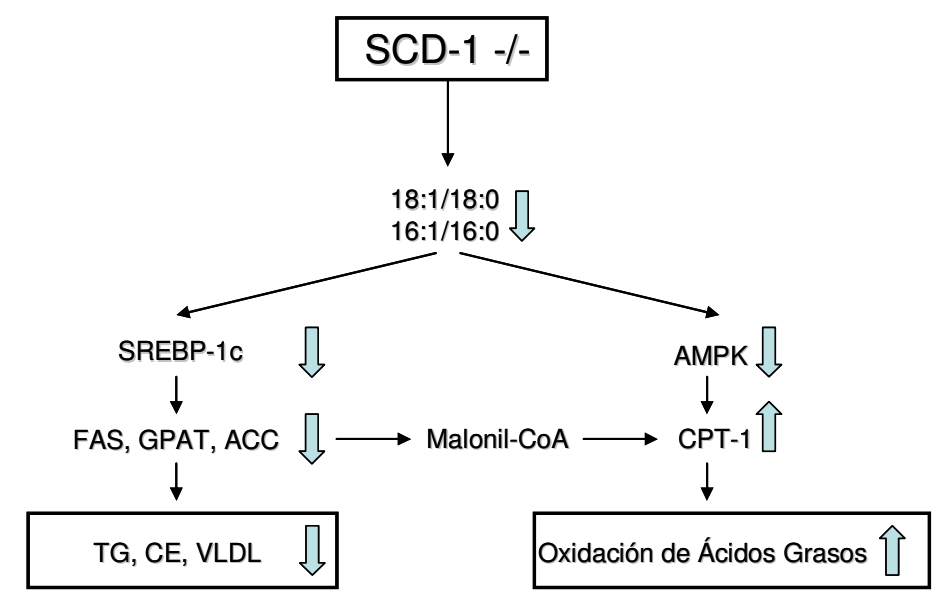

Fig. I. 4 Efecto de la inactivación de SCD sobre la síntesis y oxidación de ácidos grasos.

Además, se han logrado mejoras similares en el balance energético y en el metabolismo a través de la des-regulación de la SCD1 mediante el uso de oligonucleótidos antisentido (Jiang, G y col., 2005). En ratones ob/ob deficientes en SCD1 se observó una atenuación de la obesidad, de la hiperinsulinemia y de la esteatosis hepática (Cohen, P, 2002), y más recientemente (Gutierrez-Juarez, R, 2006), también mediante tratamiento con oligonucleótidos antisentido específicos de secuencia contra SCD1, se ha logrado restituir la sensibilidad a la insulina en ratas tratadas con dieta rica en grasas y productora de resistencia insulínica. Estos trabajos colocan nuevamente a esta enzima en los primeros planos cuando se tratan de encontrar mecanismos responsables para la aparición de patologías dependientes de la resistencia a la insulina, como la Diabetes Mellitus de tipo II.

\section{I.C.2 $\Delta 6$ y $\Delta 5$ Desaturasas.}

Los organismos eucariotas sintetizan PUFAs para mantener una viscosidad apropiada de las biomembranas pero principalmente para producir diferentes efectores moleculares. Debido a que las desaturasas 
del tipo de la $\Delta 9$ desaturasa utilizan como sustratos AG saturados, se requiere de un segundo grupo de desaturasas para cumplir con esta función. En dichos organismos, encontramos dos grandes grupos de estas enzimas. En el primer grupo aparecen las que son capaces de colocar el siguiente doble enlace entre uno pre-existente y el extremo metílico del ácido graso correspondiente, llamadas desaturasas "methylend". En el segundo grupo, están las desaturasas que encontramos en los mamíferos, que colocan el doble enlace entre un doble enlace preexistente y el extremo carboxílico de su sustrato, y que se denominan desaturasas "front-end", salvo una excepción que se comentará más adelante.

\section{a) $\Delta 6$ desaturasa}

Ya se han mencionado previamente muchas de las propiedades de los ácidos grasos poliinsaturados (PUFAs) de 18 o más átomos de carbono. Además, recientemente han cobrado importancia los PUFAs de entre 20 y 22 átomos de carbono (particularmente el ácido docosahexaenoico, 22:6n-3) como componentes de la dieta y en relación a su efecto protector de la salud cardiovascular y a su intervención en el desarrollo del sistema nervioso. A pesar del gran esfuerzo realizado durante muchos años para lograr la purificación de las enzimas responsables de esta parte de la vía, y de esta manera poder realizar la caracterización de las mismas, debió esperarse al desarrollo de las técnicas de biología molecular para alcanzar este objetivo final. Por esto, hasta el año 1997, ninguno de los genes específicamente implicados en la biosíntesis de PUFAs había sido identificado. El gen de la $\Delta 6$ desaturasa ha sido identificado y clonado en humano y ratón (Cho, HP y col., 1999a) y en rata (Aki, T y col., 1999) encontrándose proteínas de 444 aminoácidos para los tres casos, con una similitud del 87\% entre las de humano y ratón. 
La $\Delta 6$ desaturasa es una enzima de membrana que se encuentra en el retículo endoplasmático en animales. Junto a la $\Delta 5$ desaturasa, cataliza uno de los pasos regulatorios de la sintesis de ácidos grasos insaturados de cadena larga, PUFAs, a partir de ácidos grasos esenciales. A diferencia de la SCD, esta enzima contiene un dominio citocromo b5 fusionado en su extremo N-terminal, el cual cumple el rol de donor de electrones durante la desaturación. A pesar de que se demostró, a través de mutagénesis dirigida sobre el sitio ligador de hierro, que este dominio es esencial para el funcionamiento enzimático, y que el citocromo b5 libre no puede complementar estas mutaciones, la co-expresión de este cofactor libre produce un aumento de la actividad de la enzima en su forma funcional, lo que sugiere que si bien el citocromo b5 libre no es absolutamente necesario, el mismo puede llegar a jugar algún rol en esta vía metabólica (Guillou, H y col., 2004).

Otra importante diferencia en comparación con la $\Delta 9$ desaturasa es que la tercera caja de histidina posee el primero de los residuos de reemplazado por uno de glutamina, el cual es esencial para su funcionamiento (Sperling, P y col., 2003).

Esta enzima cataliza el pasaje de ácido linoleico (18:2n-6) a ácido gama linolénico (18:3n-6) y de ácido alfa linolénico (18:3n-3) a ácido estearidónico (18:4n-3). Más recientemente también se ha demostrado su participación en la conversión de 24:4n-6 a 24:5n-6 y de 24:5n-3 a 24:6n-3, ambos productos intermediarios de la ruta peroxisomal que conduce a la biosintesis de 22:5n-6 y 22:6n-3 (DHA) (D’Andrea, S y col., 2002). En todos los casos, la enzima posee una mayor afinidad por sustratos de la serie n-3. A partir de diferentes trabajos, se comenzó a crear una controversia con respecto a la posible existencia de diferentes isoenzimas para los distintos pasos catalizados por la $\Delta 6$ desaturasa. Por ejemplo, un trabajo (Inagaki, K y col., 2003) propone la existencia 
de más de una isoenzima debido a la observación de que el knock down de la $\Delta 6$ desaturasa, mediante un ARN antisentido, no impide la conversión de 18:2n-6, 18:3n-3 y 22:5n-3. Similarmente, Miyazaki y col. (Miyazaki, M y col., 2002) sugieren que la conversión de 16:0 a 16:1n-10, la cual está incrementada en tejidos con baja actividad SCD1 y en ratones (SCD1//), podría deberse a una enzima diferente a la $\Delta 6$ desaturasa ya conocida. Sin embargo, Guillou y col. (Guillou, H y col., 2003) probaron que la misma $\Delta 6$ desaturasa de rata involucrada en las conocidas conversiones antes mencionadas es capaz de llevar a cabo el pasaje de 16:0 a 16:1n-6 (lo cual es una excepción a la característica "front end" de este tipo de enzima). Finalmente, se puede comentar que, a pesar de todas las investigaciones al respecto, nunca se pudo aislar ninguna de tales otras isoenzimas, así como tampoco se pudo asignar función alguna a la proteína codificada por el gen FADS3.

Finalmente, con respecto a su estructura, si bien la enzima no ha podido ser purificada, se cree que la misma adopta una conformación en la membrana del retículo endoplasmático similar a la de $\Delta 9$ desaturasa, con sus extremos $\mathrm{N}$ y C-terminal, al igual que un segmento hidrofilico intermedio, protruyendo hacia el lado citoplasmático. Además, es posible que, como ya se comentó previamente, exista un aporte de electrones a través de un citocromo b5 libre, el cual se ubicaría entre la citocromo b5 reductasa y la propia enzima.

\section{b) $\Delta 5$ desaturasa}

Con respecto a esta enzima, clonada para el caso de humano (Cho, HP y col., 1999b), rata (Zolfaghari, $\mathrm{R}$ y col., 2001) y ratón (Matsuzaka, T y col., 2002), se puede decir que es la menos estudiada de las tres desaturasas de ácidos grasos de mamíferos.

Como ya se ha comentado, al igual que la $\Delta 6$ desaturasa, ocupa uno de los principales sitios de regulación de la biosintesis de ácidos 
grasos. Cataliza el pasaje de 20:3 a 20:4 (ácido araquidónico) dentro de la serie n-6, y de 20:4 a 20:5 dentro de la serie n-3, además de participar en la ruta de biosintesis menos importante de 20:3n-9 (Brenner, RR, 2003).

Desde el punto de vista de su secuencia polipeptídica y de su probable estructura de membrana se parece mucho a lo visto para el caso de la $\Delta 6$ desaturasa. La isoforma de rata posee 447 aminoácidos, compartiendo un $97 \%$ de identidad con la $\Delta 5$ de ratón y un $88 \%$ de identidad con su contraparte humana. Como en el caso de la $\Delta 6$ desaturasa, contiene un dominio hidrofóbico N-terminal homólogo al dominio de unión a hierro del citocromo b5 y tres cajas de histidina hacia el lado citosólico, los que pueden ser fundamentales para su actividad catalítica.

Se expresa en la mayoría de los tejidos, principalmente en hígado, cerebro, glándula mamaria y glándula adrenal, y un poco menos en riñón, ojo, páncreas y pulmón (Zolfaghari, R y Ross, AC, 2003).

El gen que codifica a $\Delta 5$ desaturasa (FADS1 en humano y Fads 1 en rata) se encuentra vecino al de $\Delta 6$ desaturasa (FADS2 para humanos y Fads2 para rata), pero en forma cabeza-cabeza, por lo que comparten una zona intermedia que probablemente se encargue de la regulación de la expresión de ambos genes. Además, en la cercanía de estos genes, se ha caracterizado la presencia del gen FADS3 (o Fads3 para rata), el cual posee muchas características que lo ubican dentro de la misma familia de las desaturasas, aunque hasta ahora no se ha demostrado la presencia de ningún transcripto ni de ninguna enzima derivada de dicho gen (Zolfaghari, R y Ross, AC, 2003). 


\section{I.C.3 Regulación de las Desaturasas.}

\section{a) Acción de los PUFAs a través de SREBP-1c y PPAR-a.}

Las células de mamíferos requieren cantidades específicas de ácidos grasos poliinsaturados en sus FL para mantener y regular las propiedades fisicas de membrana y para diferentes funciones celulares. En el hígado, también se requieren PUFAs para la síntesis de TG y de CE. Las desaturasas de mamíferos están reguladas principalmente a nivel transcripcional. Responden al principio hallado en general en organismos superiores, a través del cual la expresión de los genes se modula a través de regulación transcripcional compleja mediante la combinación de múltiples factores de transcripción para no incrementar el número de genes (Levine, M y Tjian, R, 2003). Por lo tanto, el mecanismo regulatorio de estas enzimas nos presenta un ejemplo de regulaciones transcripcionales sofisticadas.

Los PUFAs son los componentes dietarios principales que regulan a las tres desaturasas. Tanto $\Delta 9, \Delta 6$ como $\Delta 5$ desaturasa son suprimidas por los PUFAs de la dieta (Nakamura, MT y Nara, TY, 2004). El 18:1n-9, uno de los productos de la $\Delta 9$ tiene un efecto muy inferior al de los PUFAs para ejercer este tipo de supresión sobre dichas enzimas, siendo el mismo casi nulo.

Dos factores de transcripción, el sterol response element binding protein (SREBP-1c) y peroxisome proliferator-activated receptor-a (PPARa) juegan un papel de importancia en la regulación de la expresión de las desaturasas a través de los PUFAs.

$\underline{\text { Rol de SREBP-1c }}$

Los SREBPs son factores de transcripción de la familia de basic helix-loop-helix leucine zipper (bHLHLZ) que se hallaron inicialmente como factores que se unen a los sterol regulatory elements (SRE) en el promotor del gen del receptor de lipoproteínas de baja densidad (Briggs, 
MR y col., 1993). Poseen dos isoformas, SREBP-1 y SREBP-2, que se transcriben a partir de genes diferentes (Hua, X y col., 1993). A su vez, SREBP-1 posee dos subformas, SREBP-1a y SREBP-1c, codificados por el mismo gen y originados a través de splicing alternativo (Shimomura, I y col., 1997). SREBP-2 activa principalmente la transcripción de genes involucrados en la sintesis y metabolismo de colesterol, mientras que SREBP-1c actúa sobre genes para la síntesis de ácidos grasos y SREBP1a actúa sobre ambas vías (Horton, JD y col., 2002). En hígado, la isoforma predominante es SREBP-1c (Shimomura, I y col., 1997). Los SREBPs se sintetizan y ubican en la membrana del RE, desde donde su segmento N-terminal, luego de un corte proteolítico, migra hacia el interior nuclear para activar a sus genes blanco (Brown, MS y Goldstein, JL, 1997).

En el hígado de los mamiferos, SREBP-1c activa todos los genes para la síntesis de ácidos grasos, incluyendo a las tres desaturasas, habiéndose identificado su unión a los promotores de acetil-CoA sintasa, acetil-CoA carboxilasa, ácido graso sintasa y elongasa, entre otros, y dentro de las desaturasas, de SCD y $\triangle 6$ desaturasa (Nakamura, MT y Nara, TY, 2004).

SREBP-1c también media la inhibición de SCD y de $\Delta 6$ desaturasa por parte de los PUFAs. Estos, suprimen la transcripción de las desaturasas reduciendo la cantidad de la forma activa de SREBP-1c, a través de más de un mecanismo. Primero, los PUFAs de la dieta reducen la forma nuclear de SREBP-1c en ratas y en células HEK193 (Xu, J y col., 1999; Hannah, VC y col., 2001), mientras que la trioleina no tiene ningún efecto. Segundo, los PUFAs reducen la estabilidad del ARNm de SREBP-1c (Xu, J y col., 2001). Además, los ácidos grasos insaturados inhiben la activación de SREBP-1c mediada por otro factor de transcripción, el liver $X$ receptor a (LXRa), actuando como ligandos 
antagonistas (Rahman, SM y col., 2003). Sin embargo, esta supresión del SREBP-1c a través del PUFAs resta ser demostrada in vivo. Además, SREBP es capaz de regular su propia expresión debido a que su propio promotor posee un SRE (Chen, G y col., 2004).

Este factor de transcripción no solo actúa sobre los genes de síntesis de PUFAs, sino también de MUFAs, aunque solo los productos de los primeros suprimen su acción. A su vez, si bien tanto los sustratos como los productos de la $\Delta 5 / 6$ desaturasas inhiben al factor, el efecto es más marcado para el caso de los ácidos grasos más insaturados (Mater, MK y col., 1999).

\section{$\underline{\text { Rol de PPAR-a }}$}

Este factor de transcripción, posee tres isoformas: PPAR-a, PPARҮ $\mathrm{yPPAR}-\beta / \delta$.

PPAR-a es la isoforma que se expresa con mayor preferencia en hígado (Braissant, O y col., 1996). Su principal función es la de promover la degradación de ácidos grasos ( $\beta$ y $\omega$-oxidación) (Schoojans, K y col., 1996), aunque además se le conocen otras funciones y acciones en otros tejidos que contribuyen a producir efectos antiinflamatorios y anti-aterogénicos (Brenner, RR, 2006). Una de las enzimas activadas en mayor proporción como consecuencia de su acción es la acil-CoA oxidasa, la cual constituye un reportero muy útil cuando se trata de evaluar la activación de la actividad transcripcional de este factor. También otras enzimas como acil-CoA sintasa, carnitina palmitoil transferasa, proteína lipasa y las mismas desaturasas de ácidos grasos figuran entre otras capaces de ser inducidas llevando a cabo, salvo en el caso de las desaturasas, un aumento de la degradación de ácidos grasos. En estudios con células en cultivo, se detectó la presencia de PPRE en los promotores de SCD (Miller, CW y Ntambi, JM, 1996) y de $\Delta 6$ desaturasa (Tang, C y col., 2003) humanas. 
Como todos los miembros de esta familia, PPAR-a posee un dominio de unión a $\mathrm{ADN}$ y un bolsillo hidrofóbico para la unión de un ligando. Al unirse un ligando, el mismo causa un cambio conformacional en PPAR-a, el cual forma un heterodímero con algunas de las isoformas ( $a, \beta \circ \gamma)$ del retinoic $X$ receptor $(\mathrm{RXR})$, activando sus genes blanco mediante la unión del heterodimero al peroxisome proliferator response element (PPRE) de sus zonas promotoras (Chawla, A y col., 2001). Los compuestos hipolipidémicos llamados proliferadores peroxisomales, como los fibratos, inducen las enzimas de oxidación de los ácidos grasos actuando como ligandos de PPAR-a, y en roedores, no así en humanos, causan proliferación peroxisomal hepática (Reddy, JK y Hashimoto, T, 2001). Los ácidos grasos de cadena larga no esterificados son considerados los ligandos endógenos de PPAR-a (Forman, BM y col., 1997), siendo el ácido eicosapentenoico (20:5n-3) el de mayor actividad, mientras que lo ácidos grasos saturados son prácticamente inactivos. Sin embargo, los ácidos grasos saturados unidos a CoA si son capaces de activar a este factor de transcripción (Ljung, B y col., 2002). Además, PPAR-a activa la transcripción de la liver fatty acid binding protein (L-FABP) la que funciona como transportador de los agonistas de PPAR-a como los AG libres (Wolfrum, C y col., 2001). También algunos eicosanoides específicos endógenos son capaces de activar a los PPARs. Esta isoforma de PPAR es regulada positivamente por los glucocorticoides y negativamente por la insulina (Desvergne, B y Wahli, W, 1999).

PPAR $-\gamma$ posee tres isoformas, $\gamma-1, \gamma-2$ y $\gamma-3$, los que difieren en sus aminoácidos N-terminales, aunque derivan del mismo gen utilizando promotores diferentes y mecanismos de corte y empalme alternativos. La isoforma $\gamma-2$ se expresa mayoritariamente en tejido adiposo, mientras que PPAR- $\gamma-1$ se expresa en baja proporción en 
hígado y otros tejidos. La insulina y los corticoesteroides producen un aumento de la transcripción de PPAR- $\gamma$ en adipocitos, mientras que el ayuno la inhibe. La actividad transcripcional de PPAR $-\gamma$ puede ser incrementada también por ligandos naturales como los AG libres y por prostanoides como la $15-$ desoxi- $\Delta^{12-14}$ prostaglandina $J_{2}$, o por xenobióticos específicos como las tiazolidinedionas (troglitazona, rosiglitazona, pioglitazona), de los cuales solamente troglitazona es capaz de inducir la expresión de PPAR- $\gamma$ en hígado. Como consecuencia de la activación de estos PPAR- $\gamma$, se produce la activación trascripcional de diversas enzimas involucradas en la degradación de lípidos, como lipoproteína lipasa, ácido grasos translocasa, aunque también de la enzima málica que es importante para la sintesis de ácidos grasos (Brenner, RR, 2006).

Se han hallado algunas formas mutantes de PPAR- $\gamma$ encontradas en humanos que son capaces de provocar alteraciones en el metabolismo de la insulina.

Por su parte, PPAR- $\beta / \delta$, el último en ser identificado y el cual desempeña sus funciones en músculo, posee importantes funciones en la biología de la piel, el metabolismo lipídico y la homeostasis energética.

Es importante destacar que la inducción de las desaturasas tanto por PPAR-a como por SREBP-1c es paradójica debido a que, excepto en el caso de las desaturasas, estos dos factores de transcripción inducen genes mutuamente excluyentes. SREBP-1c induce la síntesis de ácidos grasos mientras que PPAR-a induce su oxidación.

El mecanismo de inducción de las desaturasas por parte de PPAR-a, al menos en el hígado de roedores, puede ser en parte indirecto. Los proliferadores peroxisomales administrados pueden inducir la degradación de ácidos grasos en peroxisomas y mitocondrias, 
por lo que se incrementa la demanda de ácidos grasos para los fosfolipidos de membrana, lo que resulta en la inducción de las desaturasas. De hecho, a pesar del aumento de síntesis de PUFAs, no se observa un cambio significativo en los fosfolipidos de membrana (Kawashima, Y y col., 1990). Además, si bien el efecto de PPAR-a sobre los genes de oxidación de ácidos grasos es muy rápido, la inducción observada en las desaturasas es más lento (Song, He W y col., 2002), a modo de compensación.

Se observó que, en ratones knock out para PPAR-a, el ARNm de $\Delta 6$ no se indujo por dieta deficiente en ácidos grasos, a pesar de que la forma nuclear de SREBP-1c aumentó (Li, Y y col., 2005), demostrando que SREBP-1c solo no es suficiente para inducir la $\Delta 6$ desaturasa humana cuando los PUFAs están bajos.

También es importante señalar el trabajo de Matsuzaka y col. (Matsuzaka, T y col., 2002) quienes encuentran que tanto la $\Delta 5$ y $\Delta 6$ desaturasas no modifican sus niveles de ARNm bajo tratamiento de ayuno-realimentación en ratones. Los autores proponen que durante el ayuno, estas enzimas estaría reguladas principalmente por PPAR-a mientras que por SREBP-1c durante la realimentación, con el resultado de que, sin importar la carga energética, estas enzimas producen niveles estables de PUFAs, los que son esenciales para las funciones celulares. Por lo tanto, esta regulación a través de PPAR-a estaría separada temporalmente de la de SREBP-1c. 


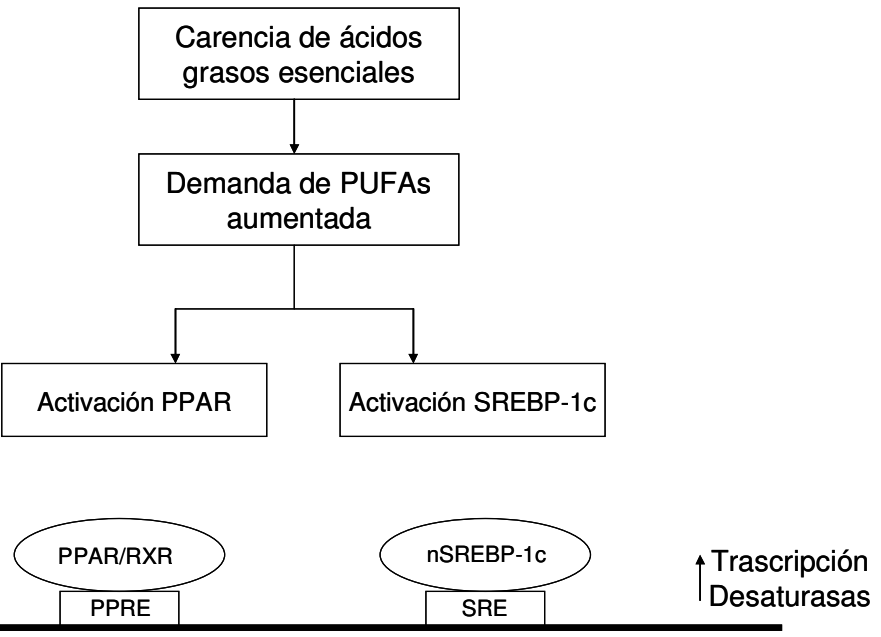

Fig. I. 5 Acción de PPAR-a y SREBP-1c, generalmente antagónicos, salvo en esta excepción, actuando como sensores del nivel de PUFAs para regular la acción de las desaturasas (adaptada de Nakamura y col. Annu. Rev. Nutr. 2004).

\section{b) Acción de la insulina a través de SREBP-1c.}

Se ha demostrado que una dieta con alto contenido de carbohidratos, administrada luego de un ayuno, incrementa rápidamente la $\mathrm{SCD}$ y su ARNm en el hígado de roedores (Ntambi, JM, 1995), así como que tanto el SREBP-1c y su ARNm disminuyen con el ayuno y aumentan rápidamente con la re-alimentación $(\mathrm{Xu}, \mathrm{J}$ y col., 2002). A su vez, se ha visto que la disrupción del gen SREBP-1c anula la inducción de SCD mediante la misma dieta (Liang, G y col., 2002).

En nuestro instituto se ha confirmado muchas veces que la inyección de estreptozotocina, fármaco que actúa dañando las células $\beta$ del páncreas, disminuye la actividad y el ARNm de las desaturasas, los que se re-inducen ante la administración de insulina, demostrándose que a su vez esta inducción se inhibe por dibutiril-AMP cíclico (70\%) y por cicloheximida (90\%), lo que muestra que la insulina necesita de la sintesis de alguna/s otra/s proteína/s para ejercer su inducción sobre las desaturasas, y que no solo la disminución de insulina inhibe a las 
enzimas, sino también el aumento de glucagón (Rimoldi, OJ y col., 2001).

Además de los controles en la expresión de SREBP ya mencionados más arriba, este factor de transcripción se encuentra regulado también a nivel de su maduración proteica. Su extremo Cterminal se encuentra unido a la proteína activadora del clivaje de SREBP (SCAP), complejo que, ante determinados eventos de señalización como la elevación en el nivel de colesterol, viaja al Golgi en donde sufre dos eventos de clivaje para liberar la forma madura de SREBP. Por su parte, la insulina es capaz de activar la transcripción de SREBP-1c mediante, aparentemente, la producción de un ligando activador de LXRa (Chen, G y col., 2004). La misma hormona, es capaz de inhibir la producción de INSIG-2, una proteína encargada de retener a SREBP en el RE e impedir su maduración (Hegarty, BD y col., 2005).

La combinación de todos estos resultados sugiere que el SREBP1c es el mediador, al menos en parte, del efecto de la insulina sobre las desaturasas y sobre otros genes lipogénicos. Además, estudios en hepatocitos de rata en cultivo han mostrado que la anulación de la expresión de SREBP-1c bloquea el efecto de la insulina sobre genes involucrados en la síntesis de ácidos grasos, mientras que la expresión constitutiva de SREBP-1c produce un efecto similar al insulinico (Foretz, M y col., 1999).

\section{c) Acción de los carbohidratos a través de ChREBP.}

Debido a que el almacenamiento de la energía en exceso es también una importante función de los TGs, las enzimas lipogénicas también poseen una regulación positiva por parte de los carbohidratos. Desde hace mucho tiempo se ha identificado al carbohidrate response element (ChoRE) en algunos genes, mucho más recientemente se ha aislado y caracterizado el factor responsable de tal regulación, 
denominado carbohidrate response element binding protein (ChREBP) (Yamashita, H y col., 2001). Dicho factor pertenece a la familia bHLHLZ, y bajo condiciones de alta concentración de glucosa, se desfosforila y transloca al núcleo, en donde produce la activación de sus genes blanco (Kawaguchi, T y col., 2001).

Este factor se expresa específicamente en hígado y en tejido adiposo (Yamachita, H y col., 2001), mientras que SREBP-1c se expresa en casi todos los tejidos, incluyendo aquellos que carecen de capacidad para sintetizar TG, por lo que se cree que ChREBP es el principal encargado en la inducción de genes (como ácido graso sintasa y acetilCoA carboxilasa) destinados al almacenamiento de energía en exceso.

Uno de los principales datos experimentales que llevó a pensar en que ChREBP induce a SCD fue que el ARNm de esta enzima disminuye solo parcialmente su inducción ante la re-alimentación, en animales knock-out para SREBP-1c (Liang, G y col., 2002).

Si bien la fructosa es un inductor más potente que la glucosa para los genes lipogénicos, todavía no se conoce fehacientemente si ChREBP es el mediador responsable de esta inducción.

\section{d) Acción del colesterol a través de LXRa}

Nuestro laboratorio ha demostrado que en hígado de ratas alimentadas con una dieta rica en colesterol se produce una inducción del ARNm y de la actividad de SCD1, mientras que los parámetros correspondientes a $\Delta 5$ y $\Delta 6$ desaturasas se deprimen o no varían, correspondiéndose estos cambios con modificaciones en las composiciones lipídicas de membrana (Brenner, RR y col., 2002). Otros trabajos han coincidido con estos hallazgos (Leikin, AI y Brenner, RR, 1987; Leikin, AI y Brenner, RR, 1988). Aparentemente, LXRa sería el mediador de esta inducción. 
Los LXRs son factores de transcripción pertenecientes a la familia de receptores nucleares, con la isoforma LXRa predominando en hígado y la forma LXR- $\beta$ estando más distribuida por varios tejidos (Repa, JJ y Mangelsdorf, DJ, 2002). Estos factores, al igual que PPAR, forman heterodímeros con RXR para asi interactuar con los liver $X$ receptor response element (LXRE) presentes en los promotores de sus genes blanco (Edwards, PA y col., 2002). Los genes activados por LXR están involucrados en la síntesis de ácidos biliares y en el transporte del colesterol, incrementándose de esta forma la secreción de colesterol en exceso a través de la bilis. La disrupción del gen de LXRa en ratones produce la acumulación de colesterol en el hígado (Peet, DJ y col., 1998).

Además, a través del uso de agonistas de LXRa se ha demostrado la presencia de LXRE en el promotor de SREBP-1c (Reppa, JJ y col., 2000), produciéndose a través de esta vía una activación de SCD1 y un incremento en la producción de VLDL en el hígado.

Más recientemente, también se ha demostrado la inducción del ARNm de SCD1 pero sin la participación de SREBP-1c (Kim, HJ y col., 2002; Luong, A y col., 2000). Si bien no se ha identificado un LXRE en el promotor de esta desaturasa, se cree que la misma se puede inducir a través de LXRa directamente, además de a través de SREBP-1c. Debido a que SCD es necesaria para la sintesis de CE, el rol fisiológico de este mecanismo sería el de proveer ácidos grasos monoinsaturados para esterificar el colesterol en exceso, lo cual estaría de acuerdo con el hecho de que el colesterol no induce a los genes de $\Delta 5$ y $\Delta 6$ desaturasa, los que usarían los ácidos grasos monoinsaturados producidos por la SCD1 pero para un fin distinto. 


\section{e) Acción de Leptina.}

La SCD1 posee un importante rol en la aparición de obesidad, aparentemente mediante diferentes mecanismos posibles. Primero, debido a que los MUFAs no inactivan a la acil-CoA carboxilasa 1 (ACC1) como lo hacen los AG saturados, la SCD1 puede causar un aumento de malonil-CoA y una represión sobre la carnitina palmitoil transferasa mitocondrial, produciendo, de esta manera, una disminución de la oxidación de ácidos grasos. Segundo, la regulación que posee esta enzima sobre la fluidez de membrana se ha relacionado con diabetes, obesidad y enfermedad cardiovascular. Tercero, en ratones deficientes en SCD1, se ha encontrado una disminución de la expresión de SREBP1c y de otros genes lipogénicos junto con un aumento de transcripción de genes de oxidación lipídica. Finalmente, se ha hallado que los ratones deficientes en SCD1 son a su vez deficientes en TGs y en ésteres de colesterol.

Al igual que la insulina, la leptina regula a SCD1, pero en sentido contrario, y además interacciona con insulina de varias formas. La insulina incrementa la secreción de leptina desde los adipocitos. Esta, a su vez, incrementa la sensibilidad a la insulina pero disminuye su secreción desde las células beta. En resumen, una forma de regulación de leptina sobre SCD1 es mediante la disminución de la insulina circulante. Además, mediante el uso de diferentes modelos animales se ha demostrado también una disminución específica de la transcripción de SCD1 mediante administración de leptina, siendo este efecto independiente de insulina y de SREBP-1c, por lo que en los casos diabéticos de alta insensibilidad a la insulina, la leptina se convertiría en la verdadera reguladora de la sintesis de MUFAs (Biddinger y col., 2006). 


\section{f) Acción de otros factores hormonales.}

\section{Glucagón}

En nuestro instituto se demostró que la administración de glucagón o dibutiril-AMPc a ratas disminuye la actividad de la $\Delta 6$ microsomal hepática (de Gomez Dumm, I y col., 1975), así como impide la inducción la inducción de su ARNm mediada por insulina (Rimoldi, OJ y col., 2001) También el dibutiril-AMPc produce una desactivación de la actividad enzimática de $\Delta 5$ desaturasa en ratas (de Gomez Dumm, I y col., 1980).

\section{Epinefrina}

Esta hormona produce también un efecto depresor sobre la expresión y actividad de las desaturasas, lo que fue demostrado en nuestro instituto a través de la inhibición de la disminución de expresión provocada por la epinefrina mediante la inyección de $\beta$ bloqueantes como dicloroisoproterelol o propanolol 73 del (Brenner, RR, 2003). También, la inyección del agonista de $\beta$-receptores isoproterenol produce un efecto activador similar a epinefrina.

De similar manera se ha probado el efecto inhibidor de esta hormona, a través de AMPc, sobre la inducción del ARNm de $\Delta 6$ desaturasa y sobre la expresión y actividad de la $\Delta 5$ desaturasa (Rimoldi, OJ y col., 2001; de Gomez Dumm, I y col., 1980).

\section{$\underline{\text { ACTH y Esteroides }}$}

Tanto la ACTH como la corticoesterona, como así también todos los glucocorticoides, mineralocorticoides y varios esteroides sexuales deprimen la actividad de la $\Delta 5$ y $\Delta 6$ desaturasas y activan la actividad de la $\Delta 9$ desaturasa en diferentes tejidos y lineas celulares aisladas de mamíferos, mientras que las composiciones lipídicas de membrana responden en mayor o menos medida a estos cambios en las actividades enzimáticas (de Alaniz, MJ y Marra, CA, 2003). 


\section{Otras}

También se han caracterizado algunos efectos sobre las desaturasas de ácidos grasos por parte de prolactina y de hormonas tiroideas. En todos los casos se han observado depresiones de las actividades $\Delta 5$ y $\Delta 6$ desaturasas (Brenner, $R R, 2003$ ) con mayor o menor repercusión en las composiciones lipídicas de membrana.

\section{g) Regulación postranscripcional de SCD1 hepática}

A pesar del extenso conjunto de reguladores que modulan la transcripción de SCD1, esta enzima cuenta con un sistema de regulación postranscripcional que produce que la enzima tenga una velocidad de recambio rápida, con una vida media relativamente corta de unas pocas horas (Mziaut, H y col., 2000). Como consecuencia, en el caso de las determinaciones de actividad, por ejemplo, los experimentos deben ser realizados antes de los 20 días de obtenidos los microsomas hepáticos, incluso con las muestras congeladas a $-70^{\circ} \mathrm{C}$.

La degradación de SCD1 in vitro es muy rápida cuando se incuban microsomas de rata a $37^{\circ} \mathrm{C}$ siendo además selectiva con respecto al resto de las proteínas que la rodean en la membrana del microsoma y que son más estables. A través de experimentos mediante el uso de quimeras SCD1/GFP (green fluorescence protein) se demostró que los 33 residuos de aminoácidos $\mathrm{N}$-terminales de SCD1 son los que determinan su rápida degradación a través de un sistema proteasa específico (Mziaut, H y col., 2000).

Además, en estudios hechos en carpa mediante incubación del animal a bajas temperaturas, se concluyó que, al menos en esa especie animal, el frío causa una inducción de la SCD1 que ocurre en dos etapas. Primero, ocurre una activación de desaturasa preexistente (2448 hs luego de la incubación) a través de algún mecanismo no aclarado, para luego producirse una segunda etapa de inducción (entre los 3 y 5 días luego de la incubación) a causa de un incremento en la traducción, 
correlacionándose ambos eventos con alteraciones en las composiciones de ácidos grasos de membrana (Tiku, PE y col., 1996).

\section{h) Regulación de $\Delta 5$ desaturasa hepática a través de ARN antisentido.}

Un novedoso sistema regulatorio ha sido recientemente hallado. El mismo involucra la participación de un segmento de ADN que se encuentra entre los genes que codifican para $\Delta 5$ y $\Delta 6$ desaturasas, que son vecinos pero codificados en direcciones opuestas, en humano, rata y ratón. Dicho segmento de $\mathrm{ADN}$, de entre 690 y 1350 nucleótidos, según la especie, no codifica para ningún péptido, pero es capaz de producir un ARNm que es complementario al exón 1 y al intrón 1 del ARNm de la $\Delta 5$ desaturasa. Así, mediante experimentos de expresión en células $\mathrm{CHO}$ y mediante administración de dieta rica en aceite de pescado, se ha visto que este ARNm antisentido se incrementa a la vez que disminuyen el ARNm y la actividad de $\Delta 5$ desaturasa (Dreesen, TD y col., 2006).

\section{I.C.4 Desaturasas y Diabetes Mellitus.}

Las diferentes variantes de Diabetes Mellitus pueden clasificarse dentro de dos grupos principales, las de tipo I, asociadas con una deficiencia de insulina, por lo cual alternativamente se las conoce como insulino dependientes, y las de tipo II, las que se asocian con una resistencia a la acción de la hormona y que en algunos casos se denominan insulino independientes, a pesar de que el desarrollo de la patología puede conducir, con el paso del tiempo, a una situación de deficiencia de la secreción insulinica.

Los sintomas y características de la diabetes de tipo I, de origen autoinmune, se pueden resumir como sigue: poliuria, polidipsia, fatiga, pérdida de peso, con un comienzo por lo general abrupto, acompañado 
por alteraciones en el metabolismo de carbohidratos y de lípidos, con hiperglucemia e hipoinsulinemia. Mientras tanto, la diabetes de tipo II, generalmente asociada con la edad adulta y la obesidad, presenta generalmente una hiper o normoinsulinemia, acompañada también con alteraciones en el metabolismo de los azúcares y los lípidos. Ambas variantes de la enfermedad producen numerosos cambios desde el punto de vista bioquímico y fisiológico, pero el presente trabajo solo se concentra en aquellos que están relacionados con el metabolismo de ácidos grasos.

Debido a las alteraciones que ocurren como consecuencia de la patología diabética sobre el metabolismo de los lipidos, y de los ácidos grasos en particular, se eligió a esta enfermedad, con sus diferentes variantes, como modelo para el estudio de la regulación de la expresión y actividad de las enzimas desaturantes de ácidos grasos de hígado, así como su repercusión sobre las composiciones de ácidos grasos de membrana.

En los últimos treinta años hemos acumulado una gran cantidad de evidencia respecto de la alteración de las tasas de $\Delta 9, \Delta 6$ y $\Delta 5$ desaturante tanto en Diabetes Mellitus experimental como humana tipo I (Brenner, RR, 2003). El trabajo pionero de Gellhorn y Benjamin (Gellhorn, A.; Benjamin, W, 1964), que da cuenta de la alteración en la desaturación del ácido esteárico en la rata diabética, da comienzo al estudio sistemático sobre la biosintesis de ácidos poliénoicos en la DM experimental. Inmediatamente después, Mercuri y col. (Mercuri, OF y col. 1966) revelaron que este defecto se extendia a la $\Delta 6$ desaturación de los ácidos linoleico y gama-linolénico. Estas actividades enzimáticas eran recuperables tras la inyección de insulina, pero esta restauración no se producía si se inhibía la síntesis proteica (Brenner, RR y col., 1968). Por otra parte, en ratones diabéticos se requiere la presencia de 
insulina para restaurar los niveles de ARNm de la SCD (Waters, MK y Ntambi, JM, 1994), lo mismo que en ratas diabéticas para el ARNm de la $\Delta 6$ (Rimoldi et al, 2001).

La DM también afecta la sintesis de ácidos grasos insaturados en tejidos periféricos y células circulantes (Igal, RA y col., 1991).

La linea de ratas Wistar e-Stilman-Salgado (eSS) (desarrollada en la Universidad Nacional de Rosario, Argentina) es un modelo animal único de DM espontánea similar a DM humana tipo II. Este síndrome de DM no insulino-dependiente se caracteriza por hiperglucemia, glucosuria y test de tolerancia oral a la glucosa anormal, el cual se torna progresivamente mas pronunciado con el envejecimiento. La evolución lenta de la DM en esta línea de roedores, así como las manifestaciones clinicas tempranas, es comparable a la Diabetes Mellitus no insulino-dependiente en jóvenes (Martínez, MS y col., 1988). Los disturbios bioquímicos prematuros observados en las ratas diabéticas eSS también se extienden al contenido de triacilglicéridos plasmáticos y hepáticos, los cuales se muestran aumentados junto a una mayor masa de colesterol en el tejido testicular de las ratas diabéticas. Asimismo, la fluidez de las membranas microsomales decreció consecuentemente en este último tejido. Otro modelo de DM tipo II que utilizaremos en nuestros trabajos es el provocado por una dieta rica en sacarosa (63\%), la cual es administrada a los animales apenas producido el destete y durante diferentes periodos de tiempo, de manera de poder estudiar las diferentes etapas en la evolución de esta patología (Brenner y col, observaciones no publicadas)

A pesar de la gran cantidad de estudios realizados, se ignoran todavía algunos aspectos esenciales de la Diabetes Mellitus, tales como la regulación de la expresión génica de muchas enzimas involucradas 
en el metabolismo lipídico, como por ejemplo las que constituyen las rutas de desaturación de AG. 


\section{I.D OBJETIVOS}

Durante el desarrollo del presente trabajo de tesis se utilizaron diferentes modelos de Diabetes Mellitus de rata, de tipo I inducida y de tipo II, inducida o genética, teniendo como objetivos principales:

a) Estudiar el rol regulador que tienen sobre el metabolismo de la biosintesis de ácidos grasos, a través de las desaturasas hepáticas, las vías de activación dependientes de:

- Insulina/SREBP-1c

- PPAR-a

- LXR-a

b) Realizar un estudio pormenorizado de las interacciones entre las distintas vías de regulación antes mencionadas, y del resultado de estas interacciones sobre el metabolismo de las desaturasas hepáticas y sobre las composiciones de ácidos grasos de membrana de hígado.

c) Realizar un aporte a la elucidación de la compleja red reguladora de la biosíntesis de ácidos grasos en el hígado de mamíferos y de las alteraciones que pueden ocurrir como consecuencia de la patología diabética de tipo I o II.

d) Determinar las influencias diferenciales de cada tipo de diabetes (I versus II) sobre:

- el nivel de expresión de SCD1, $\Delta 6$ y $\Delta 5$ desaturasas de ácidos grasos hepáticas, en rata.

- la actividad enzimática de las desaturasas hepáticas.

- las composiciones de ácidos grasos de membranas celulares, microsomales hepáticas o de las fracciones que resulten de interés en el experimento en particular, resultantes de las alteraciones producidas en los puntos anteriores. 


\section{II - METODOLOGÍA}

\section{II.A MODELOS ANIMALES, DIETAS Y TRATAMIENTOS}

\section{II.A.1 Animales}

\section{a) Ratas Wistar}

Al inicio de los diferentes tratamientos se utilizaron ratas Wistar macho de 2 meses de edad y 180-200 g de peso, provenientes del bioterio de la Facultad de Ciencias Médicas de la UNLP. Los animales se mantuvieron en cuarto de cría a temperatura controlada $\left(23^{\circ} \mathrm{C}\right)$ con ciclos fijos de luz/oscuridad de $12 \mathrm{~h}$. La alimentación que recibieron fue una dieta comercial completa (Cargill), con una composición de ácidos grasos de (porcentajes en peso) 22,5\% de 16:0, 1,3\% de 16:1, 13,7\% de $18: 0,25,9 \%$ de $18: 1 n-9,2,5 \%$ de $18: 1 n-7,30,7 \%$ de $18: 2 n-6$ y $3,4 \%$ de 18:3n-3 y agua ad-libitum.

\section{b) Ratas eSS}

Los únicos animales con características preestablecidas diferentes a las ratas Wistar fueron los de la cepa eSS (e Stilmann-Salgado), cuya denominación completa es IIMe/Fm eSS, y que deriva de la cepa IIM de ratas albinas. En algunos animales de esta cepa se detectó una hiperglucemia espontánea en ayunas, lo que llevó a caracterizar a estos animales y a establecer, en la Facultad de Medicina de la Universidad Nacional de Rosario, a la cepa eSS como modelo de diabetes no insulino 
dependiente, con características clinicas moderadas (Martínez, SM y col. 1993).

Para nuestros experimentos, utilizamos ratas eSS de 6 meses de edad, momento en el cual los animales ya han desarrollado la resistencia a la insulina con poco tolerancia a la glucosa e hipertrigliceridemia (Martinez, S.M., y col., 1988). Este modelo no posee obesidad asociada a la enfermedad. A esta edad, los animales eSS muestran hiperinsulinemia, a pesar de que con el tiempo la producción de la hormona decae (Martínez, S.M. y col., 1993).

Los animales diabéticos, junto con sus respectivos controles, recibieron una dieta comercial completa (Cargill) y agua ad libitum, y fueron mantenidos en cuarto de cría a temperatura controlada $\left(23^{\circ} \mathrm{C}\right)$ con ciclos fijos de luz/oscuridad de 12 h.

\section{II.A.2 Tratamientos Realizados para Obtener Modelos Diabéticos \\ a) Inducción de diabetes tipo I mediante inyección de estreptozotocina}

Para obtener animales que representen un modelo de diabetes mellitus tipo I (insulino dependiente), se partió de ratas Wistar macho de 180-200 g, a las que se les suministró estreptozotocina (STZ, Sigma Chemical) en una dosis única de $70 \mathrm{mg} / \mathrm{kg}$ de peso (disuelta en buffer citrato $10 \mathrm{mM}, \mathrm{pH} 4,5)$ a través de inyección subcutánea, mientras que los controles solo recibieron el vehículo. Esta droga se sabe que produce una destrucción de las células $\beta$ pancreáticas en una forma bastante rápida, provocando como consecuencia una caída en el valor sérico de insulina en forma casi proporcional a la concentración suministrada de la droga.

Una semana después de la inyección de STZ, se consideraron diabéticos aquellos animales que presentaron una glucemia $>300 \mathrm{~g} / \mathrm{dl}$. 


\section{b) Inducción de diabetes tipo II con dieta rica en sacarosa}

Otro tratamiento que se usó para obtener animales modelo de diabetes, en este caso de tipo II, fue la administración de dieta rica en sacarosa (alto contenido de fructosa). Este hidrato de carbono provoca una intolerancia a la glucosa asociada con hiperinsulinemia, AG libres incrementados, e hipertrigliceridemia (Tobey, TA y col., 1982; Lombardo, YB y col., 1983). Este efecto aparece en tres pasos: a) Inducción (semana 3-5): caracterizado por hipertrigliceridemia, un incremento moderado de los AG libres plasmáticos, hiperinsulinemia, e intolerancia a la glucosa alterada; b) Adaptación (semanas 5-8): con una normalización espontánea de los parámetros antes mencionados; y c) Recurrencia (luego de la semana 8): con hiperglucemia moderada con normoinsulinemia, hipertrigliceridemia, AG libres plasmáticos elevados y intolerancia a la glucosa severa (resistencia a la insulina).

En nuestro laboratorio se demostró que la fructosa (usada en lugar de sacarosa) como suplemento dietario durante 3 días elevó la desaturación del ácido esteárico en ratas control y diabéticas por estreptozotocina (Mercuri, O y col., 1974). Más recientemente, Waters y Ntambi (Waters, KM y Ntambi, JM, 1994) demostraron que la administración del mismo hidrato de carbono durante 24 horas incrementó el ARNm de SCD1 en ratones diabéticos, efecto que fue independiente de la insulinemia.

La dieta tuvo la siguiente composición: (porcentajes en peso) 63\% de sacarosa, $17 \%$ de caseina libre de vitaminas, 5\% de aceite de maíz, 10\% de celulosa, 3,5\% de mezcla de sales (AIN-93M-MX), 1\% de mezcla de vitaminas (AIN-93-VX; 12), 0,2 de cloruro de colina, y 0,3\% de metionina; con porcentajes de ácidos grasos de 12,54\% de 16:0, 0,20\% de $16: 1,2,77 \%$ de $18: 0,32,30 \%$ de $18: 1 n-9,51,52 \%$ de $18: 2 n-6, y$ 0,67\% de 18:3n-3. La dieta fue isoenergética con la dieta de los 
animales control, los que recibieron almidón en lugar de sacarosa, proveyendo $15,28 \mathrm{~kJ} / \mathrm{g}$ de alimento, y se mantuvo durante 6 u 8 meses, según el experimento.

\section{II.A.3 Tratamiento con Insulina}

A lo largo de los distintos experimentos se realizaron diferentes tratamientos con insulina Glargina (Lantus ${ }^{\circledR}$, Laboratorios Aventis, Alemania), la cual se inyectó a las ratas a razón de $5 \mathrm{U} / \mathrm{kg}$ de peso por día, durante un periodo de acuerdo a las necesidades experimentales, mientras que los animales control recibieron solo solución fisiológica.

Este análogo de insulina humana posee dos residuos de arginina adicionales en el extremo C-terminal de la cadena $\beta$ y una sustitución de una asparagina por una glicina en la posición 21 de la cadena a, lo que la hace mas soluble a $\mathrm{pH}$ ácido ( $\mathrm{pH}$ de la inyección=4) y menos soluble al $\mathrm{pH}$ fisiológico del tejido subcutáneo, por lo que al inyectarse por vía subcutánea forma un microprecipitado. Este efecto produce un incremento inicial de insulinemia entre las 2 y las 4 horas, y posteriormente una concentración plasmática constante de la hormona durante alrededor de 24 horas.

La búsqueda de un tipo de insulina que mantuviese una concentración plasmática con menos variaciones durante el día, para así poder evaluar el efecto de la vía activadora dependiente de la hormona con menor variabilidad, nos condujo, de acuerdo a consultas realizadas con el Dr. J.J. Gagliardino (CENEXA, Centro de Endocrinología Experimental y Aplicada, Fac. Cs. Médicas, UNLP) y con el laboratorio Aventis, a la elección de la insulina Glargina. Asimismo, se resolvió administrar la misma en una concentración 10 veces superior a la que se utiliza en humanos para tratar de evitar el uso simultáneo de otros tipos de insulinas o de hipoglucemiantes orales. 


\section{II.A.4 Tratamientos con Agonistas de Factores de Transcripción. \\ a) Fenofibrato}

Los fibratos son derivados del ácido a-ariloxi-isobutírico, y han sido usados durante décadas en el tratamiento de hipercolesterolemia e hiperlipidemia en humanos. Además, se ha demostrado su acción como fuertes agonistas de PPAR-a (Frederiksen, K.S y col., 2004)

Así, se probó el efecto del fenofibrato (Fen) (éster isopropílico del ácido 2-(4-[4-clorobenzoil]fenoxil) 2-metilpropanoico) (Sigma Chemical) en animales diabéticos, con o sin tratamiento de insulina, los que recibieron este fármaco a una dosis diaria de $100 \mathrm{mg} / \mathrm{kg}$ de peso, disuelto en una solución acuosa de goma arábiga al 3\% p/v, por alimentación forzada, durante nueve dias, mientras que los controles recibieron solo el vehículo.

\section{b) T0901317}

El fármaco T091317 (T09) (Laboratorios Amgen, San francisco, E.E.U.U.), activador específico de LXRa, fue administrado a los animales mediante alimentación forzada disuelta en una solución acuosa de carboximetil celulosa sódica (Anedra) al 1\% p/v. La dosis utilizada fue $10 \mathrm{mg} / \mathrm{kg}$ de peso/día durante 6 dias. 


\section{II.B MEDIDA DE PARÁMETROS PLASMÁTICOS}

Las muestras de sangre se obtuvieron mediante punción cardiaca y se centrifugaron a $200 \mathrm{~g}$ durante 10 minutos a $4{ }^{\circ} \mathrm{C}$, utilizando el suero inmediatamente o almacenándolo a $-20^{\circ} \mathrm{C}$ hasta su posterior análisis.

\section{a) Glucemia}

La medida de los niveles de glucemia (Bergmeyer, HV, 1974) se realizó utilizando un método enzimático colorimétrico comercial (Wiener Lab.) a que utiliza glucosa oxidasa y peroxidasa. La determinación se realiza en solución de 4-aminofenazona en buffer Tris y fenol. Luego de incubar las muestras junto a los reactivos a $37^{\circ} \mathrm{C}$ durante 10 minutos, se lee la absorbancia obtenida a $505 \mathrm{~nm}$.

\section{b) Trigliceridemia}

El nivel de triglicéridos (TG) sanguíneos (Duncombe, WG, 1963) se midió usando un método enzimático colorimétrico (Wiener Lab.). E1 método utilizado emplea las enzimas lipoproteina lipasa, glicerolquinasa, glicerol fosfato oxidasa y peroxidasa para producir, a partir de la presencia de triglicéridos, la oxidación del reactivo incoloro 4-aminofenazona, lo que produce una coloración cuya intensidad se cuantifica, luego de 10 minutos de incubación a $37^{\circ} \mathrm{C}$, a $505 \mathrm{~nm}$.

\section{c) Ácidos grasos libres}

Los ácidos grasos libres en suero se cuantificaron mediante micro-método colorimétrico en el laboratorio de la Cátedra de Fisiología de la Facultad de Ciencias Veterinarias de la UNLP (Duncombe, WG, 1963).

\section{d) Insulinemia}

La concentración de insulina sérica se determinó a través de RIA siguiendo el método de Herbert y col. en el Centro de Endocrinología 
Experimental y Aplicada de la Facultad de Ciencias Médicas de la UNLP (CENEXA) (Herbert, V y col., 1965). 


\section{II.C OBTENCION DE FRACCIONES SUBCELULARES Y ANALISIS DE LÍPIDOS}

\section{II.C.1 Fraccionamiento Subcelular Hepático}

a) Obtención de homogenato total, y fracciones microsomal y peroxisomal

Luego del sacrificio de los animales, los hígados se extrajeron rápidamente y se colocaron en una solución de homogeneización enfriada en hielo que contiene sacarosa 0,25 M, ClK 0,15 M, EDTA 0,1 $\mathrm{mM}, \mathrm{N}$-acetil cisteína $1,41 \mathrm{mM}, \mathrm{MgCl}_{2} 5 \mathrm{mM}$ y buffer fosfato de potasio $62 \mathrm{mM}, \mathrm{pH}$ 7,4. Se procedió a la homogeneización del tejido en homogenizador de vidrio teflón (Tri-R Intruments) a $1000 \mathrm{rpm}$, utilizando $3 \mathrm{ml}$ de solución de homogeneización por gramo de tejido. De esta forma se obtuvo el homogenato hepático del que se reservó aproximadamente $1 \mathrm{ml}$, y el resto se centrifugó a 10.000 x g durante 20 minutos a $4^{\circ} \mathrm{C}$ en una centrífuga Sorvall. Se obtuvo un pellet que se descartó y un sobrenadante denominado sobrenadante postmitocondrial que contiene a la fracción peroxisomal. En los casos en que fue necesario, se reservó aproximadamente $1 \mathrm{ml}$ de esta fracción, y el resto del sobrenadante se filtró a través de gasa y se centrifugó a 100.000 x g durante 1 hora a $4^{\circ} \mathrm{C}$ en una ultracentrífuga Beckman modelo Optima LE-80K, utilizando un rotor de ángulo fijo $70.1 \mathrm{Ti}$. El pellet obtenido corresponde a la fracción microsomal. El mismo se resuspendió en 1,5 ml de la solución de homogeneización (Catalá, A y col., 1975). Todas las fracciones obtenidas se almacenaron a $-70^{\circ} \mathrm{C}$ hasta su utilización.

\section{b) Determinación de proteinas totales}

Para normalizar las concentraciones de las distintas fracciones obtenidas en la etapa a), se midió el contenido proteico total mediante el método de Lowry y col. (Lowry, OH y col., 1951). El primer paso implica 
la formación de un complejo cobre-proteína en una solución alcalina. Este complejo reduce posteriormente a un reactivo fosfomolíbdicofosfowolfrámico produciendo una coloración azul intensa. La reacción colorimétrica se cuantifica a $750 \mathrm{~nm}$ en un espectrofotómetro modelo He $\lambda$ ios $\beta$ (Thermo Corporation), utilizando albúmina sérica bovina como estándar.

\section{II.C.2 Composición de Ácidos Grasos}

\section{a) Extracción de lipidos}

Los lípidos totales del homogenato y de las fracción microsomal de hígado se extrajeron utilizando el procedimiento de Folch y col. (Folch, J y col., 1957) con cloroformo: metanol (2:1 v/v) y agitación, conservando una relación de veinte partes de mezcla extractiva a una parte de muestra. La mezcla resultante se filtró por papel de filtro y se agregó al filtrado un 20 \% del volumen de agua, se agitó y se dejó toda la noche a $4{ }^{\circ} \mathrm{C}$ para permitir la separación de dos fases: una superior acuosa y una inferior clorofórmica. La fase superior se separó por sifonación y la inferior, con el extracto lipídico, se llevó a seco mediante corriente de $\mathrm{N}_{2}$. Dicho extracto se conservó en un pequeño volumen de reactivo de Folch a $-20{ }^{\circ} \mathrm{C}$, en atmósfera de $\mathrm{N}_{2}$, para su posterior análisis. La cantidad total de lípidos se determinó mediante gravimetría, tomando una pequeña alícuota de lípidos resuspendidos en Folch y evaporando el solvente con nitrógeno hasta peso constante.

\section{b) Separación de fosfatidilcolina (PC) microsomal}

Los lípidos microsomales se separaron mediante cromatografia en capa fina (TLC) en placas de Sílica Gel G60 con zona de concentración (Merck) usando una mezcla cloroformo:metanol:ácido acético:agua (50: 37,5: 3,5: 2 v/v/v/v) como solvente de desarrollo. En paralelo, se sembró un estándar que revelado con $\mathrm{I}_{2}$ permitió ubicar las zonas 
correspondientes a PC en cada una de las muestras. Estas se rasparon de la placa y se extrajeron con cloroformo:metanol (1:2 v/v). Posteriormente, se redujo el volumen de solvente por evaporación con corriente de nitrógeno, se resuspendieron los lípidos en reactivo de Folch y se reservaron las muestras a $-20^{\circ} \mathrm{C}$ hasta su análisis.

\section{c) Obtención de ácidos grasos}

Para determinar la composición de ácidos grasos del homogenato y de las fracciones microsomal y fosfatidilcolina (PC) microsomal, se saponificó una alícuota de cada una de estas fracciones, resuspendidas en reactivo de Folch. Para esto, se evaporó el solvente y se agregaron 2 $\mathrm{ml}$ de $\mathrm{KOH}$ en etanol al 10\% p/v, y luego de nitrogenar los tubos, se los tapó y se los colocó a $80^{\circ} \mathrm{C}$ durante 45 minutos. Después de enfriar las muestras, se agregaron $2 \mathrm{ml}$ de éter de petróleo para extraer y desechar la fracción insaponificable. Se acidificó con 0,5 ml de $\mathrm{HCl} 12 \mathrm{~N}$ y se agregaron $2 \mathrm{ml}$ de éter de petróleo, se mezcló por agitación y se colectó la fase orgánica superior que contiene a los ácidos grasos libres, repitiendo el agregado de éter de petróleo 2 veces más. Los extractos juntados se evaporaron con $\mathrm{N}_{2}$ y los ácidos grasos libres se esterificaron agregando $2 \mathrm{ml} \mathrm{de} \mathrm{BF}_{3}$ al 10\% en metanol y nitrogenando nuevamente los tubos. La esterificación de las muestras se realizó a $64^{\circ} \mathrm{C}$ durante 1,5 h. Una vez fríos, se agregaron $3 \mathrm{ml}$ de cloroformo y se lavó tres veces con $2 \mathrm{ml}$ de agua por vez, desechando siempre la fase acuosa superior. La fase orgánica conteniendo a los ésteres metílicos de los ácidos grasos se evaporó a seco, se resuspendió en éter de petróleo y se conservó a $20^{\circ} \mathrm{C}$ hasta su análisis.

\section{d) Composición de ácidos grasos por cromatografía gas-liquido}

Se determinó la composición de ácidos grasos del homogenato y de las fracciones microsomal y fosfatidilcolina microsomal mediante separación cromatográfica de sus ésteres metílicos en una columna 
capilar Omega Wax 250 (Supelco) de $30 \mathrm{~m}, 0,25 \mathrm{~mm}$ de diámetro interno y con una película de 0,25 $\mu \mathrm{m}$, en un equipo Hewlett-Packard HP 6890. La temperatura de la columna se programó para obtener un incremento lineal de $3^{\circ} \mathrm{C} / \mathrm{min}$ desde 175 a $230^{\circ} \mathrm{C}$, identificando los picos en base a su tiempo de retención comparado con los de estándares apropiados. Los resultados se expresaron como \% relativo de las áreas de los picos. 


\section{II.D MEDIDA DE ACTIVIDADES ENZIMÁTICAS}

\section{II.D.1 Actividad Desaturante de Ácidos Grasos en Microsomas Hepáticos}

\section{a) Reacción de desaturación}

Para medir las actividades $\Delta 9, \Delta 6$ y $\Delta 5$ desaturantes se utilizaron, respectivamente, los siguientes sustratos: [1- ${ }^{14} \mathrm{C}$ ) ácido esteárico 50 $\mu \mathrm{M},\left[1-{ }^{14} \mathrm{C}\right)$ ácido linoleico $50 \mu \mathrm{M}$ y $\left[1-{ }^{14} \mathrm{C}\right)$ ácido eicosa-8,11,14trienoico $30 \mu \mathrm{M}$, a razón de $0,10 \mu \mathrm{Ci}$ por tubo. Para realizar la medida, se incubaron los sustratos con $2,5 \mathrm{mg}$ de proteína microsomal en un volumen final de $1,5 \mathrm{ml}$ a $36^{\circ} \mathrm{C}$. La mezcla de reacción contiene sacarosa 0,25 M, KCl 0,15 M, N-acetil L-cisteína 1,41 mM, NaF $40 \mathrm{mM}$, CoA (sal sódica) $60 \mu \mathrm{M}$, ATP 1,3 mM, NADH 0,87 mM, $\mathrm{MgCl}_{2} 5 \mathrm{mM}$ y buffer fosfato de potasio $40 \mathrm{mM}, \mathrm{pH}$ 7,4. Después de 1 minuto de preincubación a $36^{\circ} \mathrm{C}$, se inició la reacción mediante el agregado de la proteina microsomal, y se incubó la mezcla en tubos abiertos durante 15 min en baño termostático con agitación. Se detuvo la reacción mediante el agregado de $2 \mathrm{ml}$ de $\mathrm{KOH} 10 \% \mathrm{p} / \mathrm{v}$ en etanol. Las muestras se nitrogenaron y se saponificaron a $80^{\circ} \mathrm{C}$ durante 45 minutos. En frío, se agregaron 0,5 ml de $\mathrm{HCl} 12 \mathrm{~N}$ y $2 \mathrm{ml}$ de éter de petróleo, se agitó y se colectó la fase orgánica superior, conteniendo los ácidos grasos sustratos y productos. El agregado de éter de petróleo se repitió 2 veces más, juntando los extractos y conservándolos a $-20^{\circ} \mathrm{C}$ hasta su posterior análisis.

\section{b) Separación y cuantificación de ácidos grasos sustratos y productos mediante radio-HPLC}

Los extractos etéreos conteniendo los ácidos grasos obtenidos en el punto anterior, se evaporaron bajo corriente de nitrógeno. Los ácidos grasos se resuspendieron en $1 \mathrm{ml}$ de metanol:agua:ácido acético (85: 15: $0,2 \mathrm{v} / \mathrm{v} / \mathrm{v})$ y posteriormente se separaron mediante cromatografia 
líquida de alta resolución (HPLC) en fase reversa. Se utilizó una columna Econosil $\mathrm{C}_{18}$ de 250 x 4,6 mm, con un tamaño de partícula de $10 \mu \mathrm{m}$ (Alltech) acoplada a una pre-columna $(10 \times 4 \mathrm{~mm})$ rellena de $\mathrm{C}_{18}$. La fase móvil que se usó fue metanol:agua:ácido acético (90: 10: 0,2 $\mathrm{v} / \mathrm{v} / \mathrm{v}$ ) a un flujo de $1 \mathrm{ml} / \mathrm{min}$ y fue impulsada por un sistema de bombas para solvente Merck-Hitachi L-6200. A la salida de la columna, el efluente se monitoreó mediante un espectrofotómetro UV a $205 \mathrm{~nm}$ para la identificación de los ácidos grasos en base a su tiempo de retención. Después, el efluente se mezcló automáticamente con una solución de centelleo Ultima Flo-M (Packard Instruments) en una relación 1:3 (v/v) e ingresó a un detector Radiomatic Instruments FloOne- $\beta$ acoplado, con una celda de $0,5 \mathrm{ml}$ y a un flujo de $4 \mathrm{ml} / \mathrm{min}$. Para la cuantificación de la radiactividad asociada a los picos obtenidos en la separación, se utilizó el programa FLO-ONE (Packard).

\section{II.D.2 Acil-CoA Oxidasa Peroxisomal Hepática}

La actividad enzimática de esta enzima se evaluó mediante un ensayo espectrofotométrico midiendo la liberación de $\mathrm{H}_{2} \mathrm{O}_{2}$ característica de la $\beta$-oxidación peroxisomal de los acil-CoA. La mezcla de reacción contiene 50 nmoles de leuco diclorofluoresceína (leuco $\mathrm{DCF}$ ) , 0,2 mg de peroxidasa exógena, $4 \mu \mathrm{mol}$ de aminotriazol (inhibidor de catalasa) para que la catalasa endógena no consuma el peróxido de hidrógeno que se produce, 0,02 \% de Tritón X-100, buffer fosfato de potasio $20 \mathrm{mM}, \mathrm{pH} 7,4,50$ nmoles de palmitoil-CoA y 20-40 $\mu \mathrm{g}$ de proteina del sobrenadante post mitocondrial hepático en un volumen final de $1 \mathrm{ml}$. Se utilizó el método de Small y col. (Small, GM y col., 1985). Se preincubó la cubeta con la mezcla de reacción en oscuridad a $30^{\circ} \mathrm{C}$ durante 5 minutos, se inició la reacción con el agregado de palmitoil-CoA, midiendo la absorbancia a $502 \mathrm{~nm}$ en un 
espectrofotómetro Ultrospec 2100 (Biochrom) a $30^{\circ} \mathrm{C}$ durante 20 minutos. La actividad enzimática se calculó teniendo en cuenta un coeficiente de extinción para la diclorofluoresceína (DCF) de 1,42 x 10-5 $\mathrm{M}^{-1} \mathrm{~cm}^{-1}$. El siguiente es un esquema de la reacción enzimática.

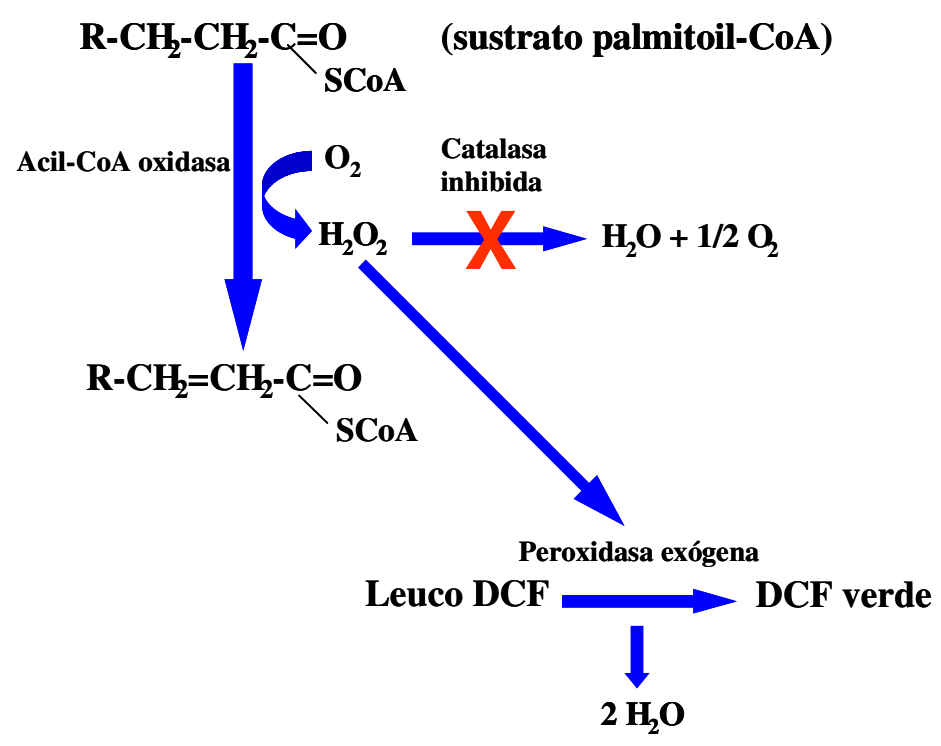

\section{II.D.3 Palmitoil-CoA Elongasa Microsomal Hepática}

La actividad de palmitoil-CoA elongasa en microsomas hepáticos se midió utilizando el protocolo descrito por Kawashima y col. (Kudo, N y col., 2003). La mezcla de reacción contiene Tris-ClH 100 mM, pH 7,4, 15 nmoles de palmitoil-CoA, 100 nmoles de malonil-CoA (0,05 $\mu \mathrm{Ci}$ de 2${ }^{14} \mathrm{C}$ - malonil-CoA), $1 \mu \mathrm{mol}$ de $\mathrm{NADPH}, 0,5 \mu \mathrm{mol}$ de $\mathrm{KCN}$ y 0,5 mg de proteina microsomal en un volumen de total de 0,5 ml. Las muestras se incubaron a $30^{\circ} \mathrm{C}$ durante 4 minutos en atmósfera de nitrógeno. La reacción se detuvo con agregado de $1 \mathrm{ml}$ de $\mathrm{KOH}$ al $10 \%$ en metanol. Las muestras se nitrogenaron y se saponificaron a $80^{\circ} \mathrm{C}$ durante 45 minutos. Se acidificó con $2 \mathrm{ml}$ de ácido clorhídrico $6 \mathrm{M}$ y se extrajo con 3 $\mathrm{ml}$ de éter de petróleo. La fase orgánica se trasvasó a otro tubo y se repitió la extracción 2 veces más, juntando las fases etéreas. Estos extractos se lavaron con $3 \mathrm{ml}$ de agua ácida para extraer el malonil-CoA sin reaccionar, se transfirieron a otro tubo, se evaporaron, se 
resuspendieron en 0,3 $\mathrm{ml}$ de éter de petróleo y se contó su radiactividad con un contador de centelleo líquido modelo 1214 RackBeta (Wallac) utilizando solución de centelleo Bray (Naftaleno 60\% p/v; PPO 4\% p/v; POPOP 0,2\% p/v; Metanol 10\% v/v; etilenglicol 2\% v/v; en dioxano). La actividad se expresa como nmoles de malonil-CoA incorporado $\mathrm{min}^{-1} \mathrm{mg}$ proteina $^{-1}$. 


\section{II.E PROTOCOLOS GENERALES DE TRABAJO CON ADN}

\section{II.E.1 Transformación de Bacterias con Plásmidos de Interés}

Todos aquellos protocolos que incluyeron trabajo con material plasmídico, comprendieron en alguno de sus pasos la transformación de bacterias. La cepa de bacterias empleada en todos los casos fue Escherichia coli JM109, las que como paso previo a su utilización en los protocolos de transformación, debieron hacerse competentes.

a) Preparación de bacterias competentes utilizando Cloruro de Calcio

Las bacterias de interés se repicaron a partir de stocks conservados $\mathrm{a}-70^{\circ} \mathrm{C}$ conteniendo los microorganismos en medio Luria Bertani (LB) (Triptona $10 \mathrm{~g} / 1$; extracto de levadura 5g/1; NaCl 10g/1; $\mathrm{PH}=7)+15 \% \mathrm{v} / \mathrm{v}$ de glicerol. Primeramente, las bacterias se crecieron por estría en placas de LB $+1,5 \% \mathrm{v} / \mathrm{v}$ de agar (LB agar) y se incubaron a $37^{\circ} \mathrm{C}$ durante una noche. Al día siguiente, se transfirió una colonia aislada a $50 \mathrm{ml}$ de medio LB, incubando el cultivo durante una noche a $37^{\circ} \mathrm{C}$ con una agitación de $175 \mathrm{rpm}$. Se trasfirieron asépticamente las células a un tubo de centrífuga estéril manteniéndolas en hielo durante 10 min. Posteriormente, las células se centrifugaron a 2.500 x g durante $10 \mathrm{~min}$ a $4^{\circ} \mathrm{C}$ y el pellet se resuspendió en $5 \mathrm{ml}$ de solución de $\mathrm{CaCl}_{2}$ 0,1 M estéril enfriado en hielo. Se centrifugó nuevamente a de la misma manera, y el pellet obtenido se resuspendió en $1 \mathrm{ml}$ de solución de $\mathrm{CaCl}_{2}$ 0,1 M estéril, conservándose a $4{ }^{\circ} \mathrm{C}$ entre 12 y 24 hs. Antes de alicuotar las bacterias competentes en tubos eppendorf de 1,5 $\mathrm{ml}$ en fracciones de $200 \mu \mathrm{l}$, se adicionó a las mismas un 20\% v/v de glicerol. (Sambrook, J y col., 1989)

Las bacterias competentes preparadas de esta manera se pueden usar inmediatamente o guardar congeladas a $-70^{\circ} \mathrm{C}$ durante varios meses. 


\section{b) Preparación de bacterias competentes por el método de Hanahan}

Se inició un cultivo de las bacterias de interés, a partir de una colonia aislada en medio LB-agar, en $100 \mathrm{ml}$ de medio LB, incubando durante una noche a $18-22^{\circ} \mathrm{C}$ con agitación. Al día siguiente, las bacterias se enfriaron en hielo durante 10 minutos y se colectaron mediante centrifugación en tubos tipo Falcon estériles a 5.000 x g durante 10 minutos a $4^{\circ} \mathrm{C}$. Luego de descartar el sobrenadante, se resuspendió el pellet de bacterias en $32 \mathrm{ml}$ de solución de competencia estéril $\left(\mathrm{MnCl}_{2} \cdot 4 \mathrm{H}_{2} \mathrm{O}\right.$ 1,088\% p/v; $\mathrm{CaCl}_{2} \cdot 2 \mathrm{H}_{2} \mathrm{O}$ 0,22\% p/v: $\mathrm{KCl}$ 1,865\% p/v; Pipes 0,01 M) enfriada en hielo, y se centrifugó nuevamente de la misma manera. El sobrenadante se descartó y el pellet de bacterias se resuspendió en $8 \mathrm{ml}$ de solución de competencia $+7 \% \mathrm{v} / \mathrm{v}$ de DMSO. Por último, las bacterias resuspendidas se alicuotaron en fracciones de $200 \mu \mathrm{l}$ y se reservaron $\mathrm{a}-70^{\circ} \mathrm{C}$ hasta su uso (Sambrook, J y col., 1989).

\section{c) Transformación de bacterias competentes}

Se adicionaron $100 \mathrm{ng}$ del ADN transformante sobre 0,2 $\mathrm{ml}$ de suspensión de células competentes, manteniendo en hielo durante 30 min. El tubo se transfirió a un baño de agua a $42^{\circ} \mathrm{C}$ para realizar un shock térmico de 90 segundos de duración. Inmediatamente el tubo se colocó en hielo y se agregó 0,8 ml de medio SOC (peptona $20 \mathrm{~g} / 1$; extracto de levadura $5 \mathrm{~g} / 1 ; \mathrm{NaCl} 0,584 \mathrm{~g} / 1 ; \mathrm{KCl} \mathrm{0,186} \mathrm{g/1;} \mathrm{Glucosa} 20$ $\mathrm{mM}$; pH 7) incubando $1 \mathrm{~h}$ a $37^{\circ} \mathrm{C}$, agitando de vez en cuando. (Sambrook, J y col., 1989)

Luego de la incubación, las bacterias se sembraron en placas de LB agar con el antibiótico de selección que corresponda (100 $\mu \mathrm{g} / \mathrm{ml} \mathrm{de}$ medio de cultivo) y se incubaron a $37^{\circ} \mathrm{C}$ durante una noche para que los transformantes desarrollen. 


\section{II.E.2 Obtención de Plásmidos en Pequeña Escala (Minipreparación)}

Básicamente consiste en una lisis alcalina de las bacterias con dodecil sulfato de sodio (SDS) para producir la liberación del plásmido a partir de las mismas. El lisado se purifica para eliminar restos celulares, proteínas y el ADN cromosómico. Este método permite obtener suficiente cantidad de ADN plasmídico para un rápido análisis del mismo.

Se transfirieron colonias individuales o anzadas a partir de stocks de glicerol, a tubos con 2-5 ml de medio LB conteniendo el antibiótico de selección que corresponda $(100 \mu \mathrm{g} / \mathrm{ml})$ y se incubaron al menos una noche a $37^{\circ} \mathrm{C}$ con agitación fuerte (175-200 rpm). Posteriormente, aproximadamente $1,5 \mathrm{ml}$ del cultivo se transfirieron en forma estéril a un tubo Eppendorf y se centrifugó a 12.000 x g durante $2 \min$ a $4^{\circ} \mathrm{C}$, repitiendo la operación 1 o 2 veces más sobre el mismo tubo, y resuspendiendo el pellet, con vórtex, en $100 \mu \mathrm{l}$ de solución I (Tris-HCl pH 8,0, 25 mM; EDTA pH 8,0, 10 mM; Glucosa 50 mM, ARNasa 10 $\mu \mathrm{g} / \mathrm{ml})$. Se adicionaron $200 \mu \mathrm{l}$ de solución II ( $\mathrm{NaOH}$ 0,2M; $\operatorname{SDS} 1 \%)$ recientemente preparada, mezclando por inversión e incubando a temperatura ambiente durante 5 minutos. A continuación, se adicionaron $150 \mu \mathrm{l}$ de solución III $(60 \mathrm{ml}$ de acetato de potasio $5 \mathrm{M}, 11,5$ ml de ácido acético, y agua destilada c.s.p. $100 \mathrm{ml}$ ) enfriada en hielo. Luego de incubar en hielo durante $10 \mathrm{~min}$, se centrifugó a 12.000 x g durante $10 \mathrm{~min}$ a $4^{\circ} \mathrm{C}$, transfiriéndose el sobrenadante a un tubo eppendorf limpio. A continuación, se procedió a purificar con $450 \mu l$ de SS-fenol:cloroformo:alcohol isoamílico $(24: 24: 1 \mathrm{v} / \mathrm{v} / \mathrm{v})$, agitando fuertemente luego de mezclar, incubando 5 minutos a temperatura ambiente y centrifugando a 10.000 x g durante 10 minutos para quedarse con la fase acuosa superior. 
Se agregaron al sobrenadante anterior 2,5 volúmenes de etanol 96\%, 0,1 volúmenes de solución de acetato de sodio $3 \mathrm{M}, \mathrm{pH} \mathrm{5,2} \mathrm{y} \mathrm{se}$ mantuvo a $-20^{\circ} \mathrm{C}$ durante $15-30$ min para que precipite el material plasmídico. Se centrifugó a 15.000 x g durante 15 min y el pellet obtenido se lavó con alcohol al 70\%, centrifugando nuevamente a $15.000 \mathrm{x} g$ durante otros 5 min y secando pellet al vacío. El pellet seco se resuspendió en $500 \mu \mathrm{l}$ de buffer TE (Tris-HCl 10 mM, pH=7,4; EDTA 0,1 $\mathrm{mM}, \mathrm{PH}=8)$ al que se le adicionaron $500 \mu \mathrm{l}$ de solución de polietilenglicol (PEG) al 13\% en $\mathrm{NaCl}$ 1,6M, se mezcló e incubó en hielo 30 min. La mezcla se centrifugó a 15.000 x g durante 15 min y el nuevo pellet obtenido se lavó con etanol al 70\%, se centrifugó nuevamente a 15.000 x g durante otros 5 min, se secó y resuspendido en $20 \mu l$ de TE. El ADN así obtenido, se conservó a $-20^{\circ} \mathrm{C}$ hasta su uso. (Sambrook, J y col., 1989, con modificaciones).

Para cuantificar la cantidad de plásmido obtenido, se midió absorbancia a $260 \mathrm{~nm}$, corrigiendo con medidas a 280 y $230 \mathrm{~nm}$.

De manera alternativa, cuando se requirió una mayor pureza en la obtención ácidos nucleicos, como por ejemplo antes de una reacción de secuenciación, se utilizó la obtención de ADN plasmídico mediante kits comerciales (Qiagen, Promega, Sigma) según las instrucciones de los fabricantes.

\section{II.E.3 Digestión con Enzimas de Restricción}

Una mezcla de reacción típica para digestión con enzimas de

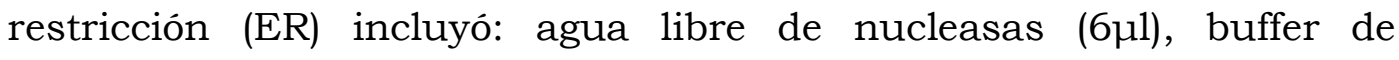
reacción 10x adecuado $(1 \mu \mathrm{l})$, ADN a analizar $(1 \mu \mathrm{g} / \mu \mathrm{l}) 50-100 \mathrm{ng}$ y ER $(10 \mathrm{U} / \mu \mathrm{l}) 2-5 \mathrm{U}$.

La mezcla de reacción se incubó durante 1-2 horas a la temperatura correspondiente para la enzima que se esté utilizando. 
Finalizada la incubación, se adicionaron $2 \mu$ de buffer para siembra en gel 6X (Glicerol 50\% v/v; buffer TAE 1 X (Tris 0,04 M; Na.Acetato. $3 \mathrm{H}_{2} \mathrm{O}$ 0,02 M; EDTA-Na $2.2 \mathrm{H}_{2} \mathrm{O} 1 \mathrm{mM} ; \mathrm{pH} \mathrm{7,2);} \mathrm{Azul} \mathrm{de} \mathrm{Bromofenol} \mathrm{1 \%} \mathrm{p/v;}$ Xyleno Xianol 1\% p/v). El volumen de mezcla de reacción, la cantidad de ER agregada y el tiempo de incubación dependieron en cada caso de la cantidad de ADN a digerir (Sambrook, J y col., 1989).

\section{II.E.4 Electroforesis Sumergida en Geles de Agarosa}

La mayoría de los protocolos en los que se utilizó material proveniente de plásmidos, se realizaron diferentes tipos de análisis utilizando separación de ADN mediante electroforesis. Para esto, se utilizaron geles de agarosa $(0,8-1,3 \%)$, realizando la corrida electroforética en cubas de electroforesis sumergidas (BioRad) a aproximadamente $10 \mathrm{~V} / \mathrm{cm}$ durante 45-90 minutos. En todos los casos, el buffer de corrida fue buffer TBE $1 \mathrm{X}$ (Tris 0,05 M; Acido Bórico 0,05 M; EDTA-Na $2.2 \mathrm{H}_{2} \mathrm{O} \quad 1 \mathrm{mM}$ ) sembrando las muestras junto con estándares de peso molecular comerciales adecuados. Las bandas de ADN se observaron a través de transiluminación UV (Hoefer MacroVue UV-20) con previa tinción de los geles con solución de bromuro de etidio $(0,5 \mu \mathrm{g} / \mathrm{ml})$. Para realizar el análisis correspondiente, los geles se fotografiaron utilizando una cámara de fotos digital KD120 (Kodak) y se analizaron con el software Kodak Digital Science 1D (Kodak).

\section{II.E.5 Aislamiento de Fragmentos de ADN a Partir de Geles de Agarosa}

Cuando la electroforesis en gel implicó la posterior utilización de los fragmentos de ADN separados, el gel se armó utilizando agarosa de bajo punto de fusión (Biorad), realizando la corrida bajo las mismas condiciones detalladas en el punto anterior, pero manteniendo la 
temperatura de la cuba electroforética por debajo de los $10-12^{\circ} \mathrm{C}$ para evitar deformaciones en la corrida debidas a la producción de calor por el paso de la corriente eléctrica.

Una vez individualizadas las bandas de interés mediante coloración con bromuro de etidio, se cortaron y extrajeron las mismas y se las colocó dentro de un tubo eppendorf junto con 3 volúmenes de buffer TE. El tubo se colocó en baño de agua a $65^{\circ} \mathrm{C}$ durante 10 minutos, agitando de vez en cuando, para fundir el gel. Se adicionó igual volumen de SS-fenol, y luego de una vigorosa agitación, se centrifugó a 10.000 x g durante $10 \mathrm{~min}$ a $20^{\circ} \mathrm{C}$. Se trasvasó la fase acuosa superior a un tubo limpio repitiendo la operación anterior con un volumen igual de SS-fenol-cloroformo y luego con cloroformoisoamílico. Finalmente, sobre la fase acuosa rescatada se agregó el 0,1 volúmenes de acetato de sodio $3 \mathrm{M}(\mathrm{pH}=5,2)$ y 2,5 volúmenes de etanol $96 \%$, conservando a $-20^{\circ} \mathrm{C}$ durante 15 min para facilitar la precipitación del ADN. Luego de este tiempo, se centrifugó 15 min a 15.000 x g a $4^{\circ} \mathrm{C}$, se lavó el pellet con etanol 70\%, se centrifugó nuevamente 5 min a la misma velocidad, se lo secó al vacío y se lo redisolvió en un volumen adecuado de buffer TE (Sambrook, J y col., 1989).

De manera alternativa, en los casos en que se necesitó de una mejor calidad de purificación, se utilizaron kits comerciales para extracción de ácidos nucleicos a partir de geles (Qiagen, Amersham), según los protocolos de los productos.

\section{II.E.6 Reacción de Ligación}

Para una reacción típica de ligación, se utilizaron 200 ng del vector en una relación molar inserto:vector de 3:1, empleando buffer ligasa $1 \mathrm{X}, 1 \mathrm{U}$ de enzima ligasa y agua libre de nucleasas hasta $10 \mu \mathrm{l}$. La incubación se realizó a $15^{\circ} \mathrm{C}$ durante aproximadamente 16 hs. 


\section{II.E.7 Obtención de Plásmidos en Gran Escala (Maxipreparación)}

Se inocularon $100 \mathrm{ml}$ de medio LB (conteniendo el antibiótico de selección correspondiente $(100 \mu \mathrm{g} / \mathrm{ml})$ con $0,5 \mathrm{ml}$ de cultivo primario de bacterias conteniendo plásmido de interés, y se incubaron durante 1216 hs a $37^{\circ} \mathrm{C}$ con agitación enérgica. El cultivó se centrifugó a 5.000 x g durante 10 min para separar las bacterias. Estas se resuspendieron en $2 \mathrm{ml}$ de Solución I, (ver minipreparación de plásmidos). Se agregaron 4 ml de Solución II, se mezcló por inversión y se incubó 5-10 min a temperatura ambiente. Se agregaron a la mezcla $3 \mathrm{ml}$ de Solución III con posterior incubación en hielo durante $10 \mathrm{~min}$. Luego de centrifugar a $12.000 \mathrm{x}$ g durante $10 \mathrm{~min}$ y rescatar el sobrenadante se adicionó 0,6 volúmenes de isopropanol, se incubó por $10 \mathrm{~min}$ a temperatura ambiente y se centrifugó a 12.000 x g durante 10 min, rescatándose el pellet obtenido y resuspendiéndolo en buffer TE. Se continuó de manera análoga a lo hecho en la minipreparación de plásmidos.

Para cuantificar la cantidad de plásmido obtenido, se midió absorbancia a $260 \mathrm{~nm}$, haciendo corrección con medidas a 280 y 230 nm (He $\lambda$ ios Beta, Thermo Corporation) (Sambrook, J y col., 1989).

\section{II.E.8 Amplificación de Fragmentos de ADN Mediante PCR}

Varios de los protocolos utilizados incluyeron la amplificación de fragmentos de ADN mediante la reacción en cadena de la polimerasa (PCR). Para estos experimentos se utilizó un ciclador modelo PCR Express (Thermo-Hybaid). El ADN obtenido por el método más conveniente, según el caso, se mezcló con los demás reactivos de reacción, que incluyeron, en una reacción típica: buffer de reacción $1 \mathrm{X}$ (con $\mathrm{Mg}^{+2}$ ); dNTPs 0,4 mM de cada uno; cebadores 1,25 $\mu \mathrm{M}$ de cada 
uno, 1,25 unidades de ADN polimerasa; en agua libre de nucleasas. En la mayoría de las reacciones de PCR se utilizó la enzima Taq polimerasa, salvo en los casos en que se produjeron fragmentos de relativa gran longitud (mas de 1000 pb) y cuando se necesitó de una alta fidelidad de copiado, en cuyo reemplazo se utilizó la enzima pfu polimerasa.

En una reacción típica, se realizaron 30-35 ciclos con los siguientes pasos: $1 \mathrm{~min}$ a $94^{\circ} \mathrm{C}$ (temperatura de desnaturalización), 0,52 minutos a $55-62^{\circ} \mathrm{C}$ (temperatura de apareamiento) y 0,5-2 minutos a $72^{\circ} \mathrm{C}$ (temperatura de extensión), precedidos por una desnaturalización del ADN molde de 4-5 minutos a $94^{\circ} \mathrm{C}$ (Sambrook, J y col., 1989).

El producto de la PCR se utilizó inmediatamente o se conservó a $20^{\circ} \mathrm{C}$ hasta su posterior utilización o análisis. 


\section{II.F DETERMINACIÓN DE PROTEÍNAS MEDIANTE WESTERN BLOT II.F.1 Producción de Anticuerpos anti-SCD1 y anti- 66 Desaturasa a) Construcción del vector de expresión}

A partir de las secuencias publicadas para SCD1 y $\Delta 6$ desaturasas de rata (Números de acceso a Genbank NM_139192 y AB021980), se diseñó un esquema de corte con enzimas de restricción para obtener la región correspondiente a los primeros 85 aminoácidos $\mathrm{N}$-terminales de $\mathrm{SCD} 1, \mathrm{y}$ se diseñaron $\mathrm{y}$ adquirieron cebadores específicos para amplificar, mediante PCR, la región codificante correspondiente a los primeros 131 aminoácidos de $\Delta 6$ desaturasa. Se usó como molde el ADNc de dichas enzimas, para el corte y posterior clonación del segmento correspondiente a los 85 aminoácidos N-terminales de SCD1, empleándose la polimerasa de alta fidelidad pfu para la reacción de amplificación del segmento correspondiente a $\Delta 6$ desaturasa. La secuencia de los cebadores utilizados fue:

directo: 5'-CAGTGGATCCATGGGGAAGGGAGGTA-3' inverso5'-CTGCTCGAGTCACAGGTGGTTGGTTTTGAAAAGG-3'

Además de amplificar la zona específica antes señalada, los cebadores agregaron al producto de amplificación secuencias de restricción para corte con BamHI (hacia 5' del amplicón) y XhoI (hacia 3' del amplicón), las que se muestran subrayadas.

Al producto de PCR obtenido, de extremos romos, se les adicionó un desoxinuclétido de Adenina en cada uno de sus extremos 3', mediante el procedimiento de A-tailing (Promega), el que constó de los siguientes reactivos
ADN amplificado
$1,5 \mu \mathrm{l}$ (aprox. $100 \mathrm{ng})$
buffer para taq pol.10 X (con $\left.\mathrm{MgCl}_{2}\right)$
$1 \mu 1$ 
taq polimerasa

dATP
$0,5 \mu l$ (5 unidades)

$1 \mu 1,0,2 \mathrm{mM}$ final

$10 \mu \mathrm{l}$

$\mathrm{H}_{2} \mathrm{O}$ libre de nucleasas c.s.p.

Después de mezclar, se incubó a $72^{\circ} \mathrm{C}$ durante 30 minutos. Posteriormente, se ligaron los fragmentos tratados al vector plasmídico pGEM-T-Easy (Promega) siguiendo las instrucciones del fabricante. E1 plásmido conteniendo el inserto pGEM-T Easy/ $\Delta 6$-Nterm, se transformó en bacterias competentes JM109, las que se plaquearon en medio LB agar con ampicilina $100 \mu \mathrm{g} / \mathrm{ml}$, para selección de transformantes, y con IPTG 0,5 mM y $80 \mu \mathrm{g} / \mathrm{ml}$ de X-gal, estos últimos reactivos para inducir la expresión del gen lacZ codificado en el plásmido, lo que permite distinguir entre bacterias que hayan incorporado el plásmido con inserto (colonias blancas) o sin él (colonias azules).

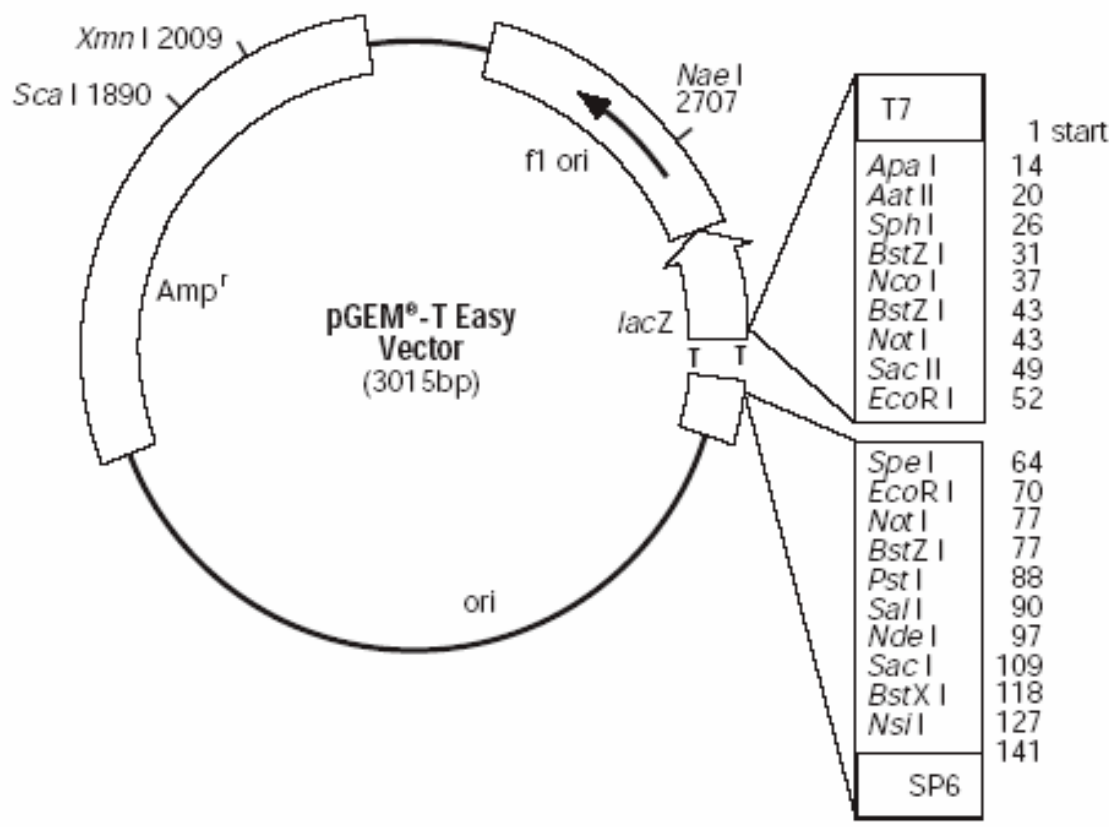

Las placas se incubaron a $37^{\circ} \mathrm{C}$ durante la noche, y al día siguiente se crecieron cultivos, a partir de colonias blancas aisladas, en $5 \mathrm{ml}$ de medio LB con ampicilina $100 \mu \mathrm{g} / \mathrm{ml}$, los que sirvieron para evaluar la presencia de pGEM-T Easy/D6-Nterm en los transformantes. 
Aquellos cultivos positivos se almacenaron en forma de stock con glicerol a $-70^{\circ} \mathrm{C}$.

A partir de un stock de glicerol se realizó una maxipreparación de plásmido. El vector purificado se cortó con las enzimas BamHI y XhoI, y el inserto cortado se purificó mediante gel de agarosa de bajo punto de fusión. En paralelo, se amplificó al vector de expresión bacteriana pGEX-4T-1 (Amersham Biosciences), el que se cortó también con las mismas enzimas de restricción y se purificó de la misma manera. Por último, se realizo la ligación del segmento de SCD1 o de $\Delta 6$-Nterm en el vector pGEX-4T-1, para dar lugar a los vectores pGEX-4T-1/SCD1 y pGEX-4T-1/ $\Delta 6$-Nterm los que se transformaron en bacterias JM109.

\section{pGEX-4T-1 (27-4580-01)}

Thrombin

Leu Val Pro Arg ${ }^{\downarrow}$ Gly Serl Pro Glu Phe Pro Gly Arg Leu Glu Arg Pro His Arg Asp

CTG GTT CCG CGT GGA TCC CCG GAA TTC CCG GGT CGA CTC GAG CGG CCG CAT CGT GAC TGA

BamHI EcoRI Smal Sall Xhol Not I Stop codons

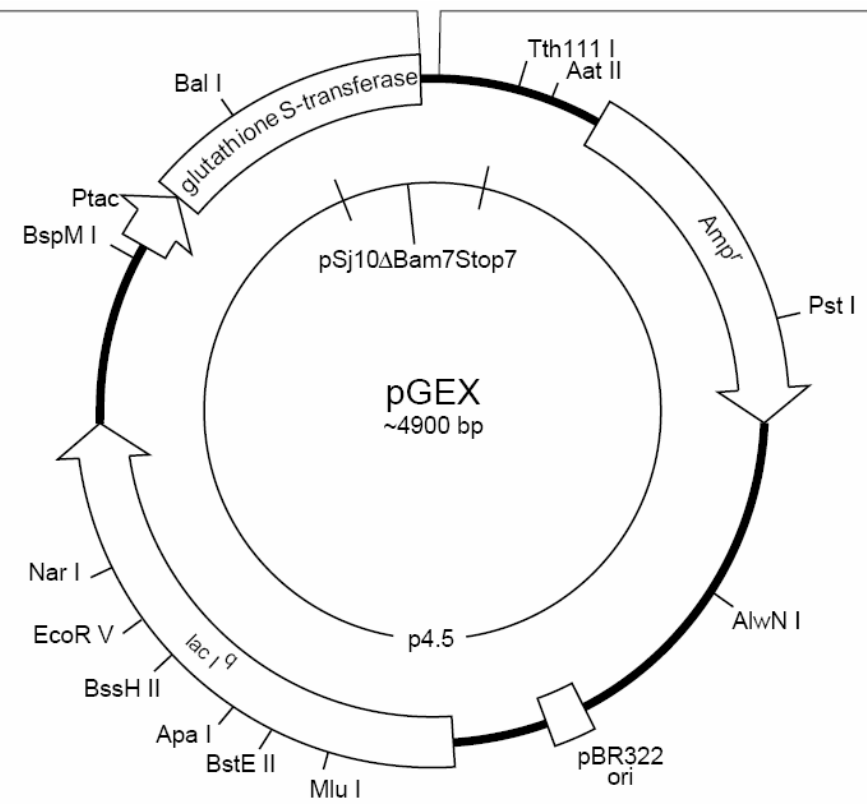

Los plásmidos pGEX-4T-1/SCD1 y pGEX-4T-1/D6-Nterm, cuando se expresan en bacterias, producen proteínas de fusión glutatión Stransferasa (GST)/SCD1 o / $\Delta 6$-Nterm, facilitándose así la detección y 
purificación de los fragmentos de interés. Antes de proseguir con la expresión, se confirmó la presencia de los vectores armados anteriormente mediante secuenciación.

\section{b) Expresión de la proteina de fusión}

En una primera etapa, se ensayó una expresión de los péptidos en pequeña escala. Para ello, se realizó un cultivo de $5 \mathrm{ml}$ en LB con ampicilina $100 \mathrm{\mu g} / \mathrm{ml}$ a $37^{\circ} \mathrm{C}$ y $175 \mathrm{rpm}$, hasta que la densidad óptica a $600 \mathrm{~nm}\left(\mathrm{DO}_{600}\right)$ del cultivo alcanzó 0,5-0,6 unidades. En ese momento, se indujo la expresión del vector mediante agregado de isopropil-beta-D-tiogalactopiranósido (IPTG) 0,5 mM, y se incubó nuevamente en las mismas condiciones durante 3 horas más. El cultivo se centrifugó a 5.000 x g durante 5 minutos para colectar las bacterias, el sobrenadante se descartó y las bacterias se resuspendieron en $100 \mu 1$ de buffer de siembra-SDS (Biorad). Después de exponer las bacterias resuspendidas a $100^{\circ} \mathrm{C}$ durante 4 minutos para producir su lisis y la liberación del péptido de interés, se sembraron $20 \mu l$ de lisado en SDSPAGE $12 \%-4 \%$, y se realizó la corrida electroforética correspondiente a $110 \mathrm{~V}$ durante 2 hs, utilizando un equipo de electroforesis Hoefer HE33 (Amersham) con una fuente de poder Power Pac 3000 BR (Biorad). El gel se tiñó con Coomasie blue, y mediante observación de las bandas obtenidas y comparación de las mismas con estándar de peso molecular, se pudo observar la aparición de una nueva e importante banda de aproximadamente $41 \mathrm{KDa}$ para el cultivo que expresaba el fragmento de SCD1 y de $44 \mathrm{Kda}$ para el de $\Delta 6$, correspondiente al peso molecular esperado para las proteínas de fusión. Como controles, se utilizaron bacterias JM109 sin plásmido, conteniendo plásmido sin inserto, o conteniendo plásmido con inserto pero sin inducir.

Una vez confirmada la capacidad de expresión de los plásmidos construidos, se procedió a realizar una expresión en gran escala. Para 
esto, los clones de bacterias elegidos en el paso anterior se cultivaron en $400 \mathrm{ml}$ de medio $\mathrm{LB}$ con ampicilina a $37^{\circ} \mathrm{C}$ y $175 \mathrm{rpm}$ hasta una $\mathrm{DO}_{600}$ de 0,5-0,6. Se indujo con 0,5 mM de IPTG y se incubó en las mismas condiciones durante 3 horas más. Posteriormente, las bacterias se centrifugaron a $5.000 \mathrm{x} \mathrm{g}$ durante 10 minutos a $4^{\circ} \mathrm{C}$ en centrífuga Sorvall y el sobrenadante se reservó para su análisis (sobrenadante 1). El pellet de bacterias se resuspendió en $20 \mathrm{ml}$ de buffer PBS $1 \mathrm{X}(\mathrm{NaCl}$ $140 \mathrm{mM}, \mathrm{KCl}, 2,7 \mathrm{mM}, \mathrm{Na}_{2} \mathrm{HPO}_{4} 10 \mathrm{mM}, \mathrm{KH}_{2} \mathrm{PO}_{4}$ 1,8 mM, pH 7,3, se agregó guanidina clorhídrica $(6 \mathrm{M}$ final) y se dejó agitando en hielo durante 2-3 hs para su lisis. Se centrifugó a 12.000 x g para colectar los detritos celulares, el pellet (pellet 1) se reservó para su análisis y se continuó con el sobrenadante. Este se dializó en bolsas de diálisis (Sigma Chemicals) dos veces contra 1 litro de $\mathrm{H}_{2} \mathrm{O}$ bidestilada, 2 horas cada vez a $4^{\circ} \mathrm{C}$, y finalmente durante una noche a $4^{\circ} \mathrm{C}$ contra PBS $1 \mathrm{X}$. Al día siguiente, el sobrenadante dializado se centrifugó a 12.000 x g para extraer cualquier precipitado formado durante la diálisis, el pellet obtenido (pellet 2) se reservó y el sobrenadante se filtró a través de filtro de $0,45 \mu \mathrm{m}$.

Para la purificación final de las proteínas de fusión se utilizaron columnas de purificación a las que se rellenó con $500 \mu$ le resina Glutatione Sepharose 4B (Amersham Biosciences), se lavó con 10 volúmenes $(5 \mathrm{ml})$ de $\mathrm{PBS} 1 \mathrm{X}$ a $4^{\circ} \mathrm{C}$, y se equilibró con $\mathrm{PBS} 1 \mathrm{X}$ a la misma temperatura. El sobrenadante celular se pasó a través de la columna, reservándose el eluato (eluato 1), y se lavó la columna con 15 $\mathrm{ml}$ de PBS 1X, reservando también este PBS de lavado. Posteriormente se agregaron $500 \mu \mathrm{l}$ de buffer de elución (glutatión reducido $10 \mathrm{mM}$, Tris-HCl 50 mM, pH 8) a la columna y se dejó a temperatura ambiente durante 30 minutos. Después de recoger el eluato, se repitió el procedimiento de elución 2 veces más, juntando los tres extractos. El 
eluato final se concentró a aproximadamente $600 \mu$ l en un concentrador Centricón de $30 \mathrm{kDa}$.

Con todas las fracciones de purificación obtenidas, se sembró un gel SDS-PAGE 12\%-4\% para investigar, mediante tinción con Coomasie blue y comparación con estándar de peso molecular, en cual de las fracciones estaban las proteínas de fusión. Se comprobó que las mismas se encontraban en la fracción eluato de la columna, en donde se encontró una banda de aproximadamente de 41 KDa (SCD1) y de 44 $\mathrm{kDa}(\Delta 6)$, con $1-5 \%$ de impurezas. Para finalizar la etapa de purificación, los eluatos concentrados que contenían las bandas proteicas de interés se dializaron contra 1 litro de agua, 2 veces ( 2 hs por vez), y finalmente contra 1 litro de PBS $1 \mathrm{X}$, siempre a $4^{\circ} \mathrm{C}$. Por último, se midió la concentración proteica en los productos de la diálisis mediante el método de Lowry.

\section{c) Inoculación en animales y obtención de anticuerpos}

Se inocularon en forma intramuscular $750 \mu \mathrm{g}$ de cada proteina de fusión a dos conejos macho jóvenes por enzima, de aproximadamente 1,5-2 kg de peso. La inyección a cada conejo se hizo dividida en varios sectores, y utilizando adyuvante de Freund. 30 días después de la primera inyección, se realizó una segunda inoculación con $400 \mu \mathrm{g}$ de cada proteína a cada animal correspondiente. A continuación se dejaron pasar 10-12 días, y se realizó el desangrado de todos los conejos utilizando punción cardiaca.

La sangre obtenida se dejó reposar para formación de coágulo y posteriormente se la centrifugó a 5.000 x g durante 10 minutos para separar el suero. Este suero se alicuotó en fracciones de $500 \mu 1$ solo o con $500 \mu 1$ de glicerol, y se lo conservó a $-70^{\circ} \mathrm{C}$. 


\section{II.F.2 Ensayo de Western blot para Medida de SCD1 $0 \Delta 6$ Desaturasa en Microsomas de Higado.}

\section{a) Separación y transferencia de proteinas}

Se sembraron $70 \mu \mathrm{g}$ de proteína microsomal por calle en gel SDSPAGE 12\%-4\%, procediendo a la separación de las proteínas a $110 \mathrm{~V}$ durante 2 hs. Una vez finalizada la electroforesis, el gel se colocó sin ninguna tinción en un equipo de transferencia para geles semi-seco (Biorad), aplicándole $12 \mathrm{~V}$ durante 1,7 horas para transferir las proteinas del gel a una membrana de nitrocelulosa Hybond ECL (Amersham Pharmacia). Antes de la transferencia, tanto la membrana de nitrocelulosa como el gel y los papeles de filtro accesorios se equilibraron durante 10 minutos en buffer de transferencia (3,03 g de Tris, 14,4 g de glicina, $200 \mathrm{ml}$ de metanol, $\mathrm{H}_{2} \mathrm{O}$ c.s.p. $1000 \mathrm{ml}$ ).

\section{b) Incubación con anticuerpos}

Una vez finalizada la transferencia, la membrana se colocó en un recipiente con solución de bloqueo de $\mathrm{PBS}-\mathrm{T}$ con leche $\left(\mathrm{Na}_{2} \mathrm{HPO}_{4}\right.$ anhidro 11,5 g; $\mathrm{NaH}_{2} \mathrm{PO}_{4}$ 2,96 g; $\mathrm{NaCl}$ 5,84; $\mathrm{H}_{2} \mathrm{O}$ c.s.p. 1000 ml; pH 7,5; Tween-20 0,1\% v/v; leche en polvo descremada (Molico) 5\% p/v) y se dejó 1 hora con agitación suave a temperatura ambiente o toda la noche a $4^{\circ} \mathrm{C}$. A continuación, se agregó el anticuerpo primario correspondiente en dilución 1/500-2000 en buffer PBS-T leche 1\% p/v, y se incubó 1,52 horas a temperatura ambiente con agitación suave, luego se removió esta solución y se lavó la membrana con buffer PBS-T 5 veces durante 5 minutos. La membrana se incubó con anticuerpo secundario anti-IgG de conejo conjugado con enzima peroxidasa (Biorad) en dilución 1/5000 en buffer PBS-T leche $1 \% \mathrm{p} / \mathrm{v}$, dejando a temperatura ambiente durante 1,5 horas con agitación suave, y al final, se repitieron los 5 lavados con PBS-T. 


\section{c) Revelado}

Se preparó solución de revelado A (luminol en DMSO; ácido cumárico en DMSO; Tris-HCl $1 \mathrm{M}, \mathrm{pH} 8,333 \mu \mathrm{l} ; \mathrm{H}_{2} \mathrm{O}$ bidestilada c.s.p. $5 \mathrm{ml})$ y solución de revelado $\mathrm{B}\left(\mathrm{H}_{2} \mathrm{O}_{2} 110\right.$ volúmenes $3,2 \mu \mathrm{l}$; Tris- $\mathrm{HCl} 1$ M, pH 8, $333 \mu \mathrm{l} ; \mathrm{H}_{2} \mathrm{O}$ bidestilada c.s.p. $5 \mathrm{ml}$ ).

Ya dentro de un cuarto de revelado, la membrana lavada en el punto anterior se incubó con una mezcla de $5 \mathrm{ml}$ de solución de revelado A y $5 \mathrm{ml}$ de solución de revelado $\mathrm{B}$ durante 1 minuto, y posteriormente, después de secar la membrana entre papeles de filtro, se la colocó en un casete de exposición (Kodak) con una placa radiográfica (Kodak), dejando exponer durante 1-5 minutos.

Para el revelado de la placa radiográfica, se sacó la misma del casete de exposición y se la pasó a una solución reveladora y se la dejó reposar durante 1 minuto o hasta aparición de bandas. Después de sacar la placa y enjuagarla rápidamente con agua corriente, se la sumergió en solución fijadora con agitación. Por último, la placa revelada se dejó secar al aire y se procedió al análisis de las bandas obtenidas.

Para realizarlo, se digitalizó la placa radiográfica, y se analizó la imagen obtenida mediante el software Digital Science (Kodak). Los resultados se expresan como unidades arbitrarias que representan la intensidad de señal relativa entre las distintas muestras. 


\section{II.G MEDIDA DE ARNm DE DESATURASAS HEPATICAS MEDIANTE NORTHERN BLOT}

a) Aislamiento de ARN total

Inmediatamente después del sacrificio de los animales, se extrajo una porción de hígado de $150-190 \mathrm{mg}$, y se conservó a $-70^{\circ} \mathrm{C}$ hasta su análisis.

Para la extracción del ARN total se utilizó el kit SV Total RNA Isolation System (Promega), siguiendo las instrucciones del fabricante. Brevemente, el protocolo consta de una homogeneización del tejido en un buffer de lisis, tratamiento térmico suave del homogenato $\mathrm{y}$ purificación a través de columnas de afinidad con un paso intermedio de tratamiento con ADNasa.

El ARN total así obtenido se cuantificó mediante medida espectrofotométrica, se alicuotó en fracciones de $20 \mu \mathrm{g}$, se llevó a seco mediante evaporación en Speed Vac y se almacenó a $-70^{\circ} \mathrm{C}$ hasta su análisis.

\section{b) Separación electroforética y transferencia}

Los pasos posteriores para la realización de la medida del nivel de los distintos ARN mensajeros se realizaron siguiendo los procedimientos generales según Sambrook (Sambrook, J y col., 1989). El ARN seco (20 $\mu g)$ se resuspendió en $10 \mu \mathrm{l}$ de una mezcla desnaturalizante $\left(\mathrm{H}_{2} \mathrm{O} 2,25\right.$ $\mu \mathrm{l}$; buffer MOPS 10X 1,0 $\mu \mathrm{l}$; formaldehído 37\% v/v 1,75 $\mu$; formamida $5,0 \mu \mathrm{l})$ agitando con vórtex, se colocó en baño a $95^{\circ} \mathrm{C}$ durante 2 minutos y se enfrió rápidamente en hielo. Luego se adicionaron $2 \mu l$ de buffer de siembra $(50 \% \mathrm{v} / \mathrm{v}$ glicerol; EDTA $1 \mathrm{mM}$; bromofenol blue 0,25\% p/v; xilenocianol 0,25\% p/v) y se sembró en un gel de agarosa $1 \% \mathrm{p} / \mathrm{v}$ - formaldehído $0,9 \% \mathrm{p} / \mathrm{v}$. Las muestras sembradas se separaron electroforéticamente utilizando buffer de corrida MOPS $1 \mathrm{X}$ a $5 \mathrm{~V} / \mathrm{cm}$ durante 3-3,5 horas. 
Al finalizar la corrida, el gel se lavó con una cantidad grande de agua bidestilada estéril y posteriormente con otra cantidad similar de buffer SSC 10X estéril ( $\mathrm{NaCl} 87,65$ g; Citrato de sodio. $2 \mathrm{H}_{2} \mathrm{O} 44,1 \mathrm{~g}$; en $1 \mathrm{~L}$ de $\left.\mathrm{H}_{2} \mathrm{O} ; \mathrm{pH} 7,0\right)$. El gel se transfirió por capilaridad a membrana nylon (Amerham Biosciences) durante 12-18 horas a temperatura ambiente, utilizando buffer SSC 10X.

Una vez finalizada a transferencia, la membrana se lavó con buffer SSC 6X durante 30 minutos, dos veces, se secó parcialmente entre papeles de filtro y se realizó el cross-linking del ARN a la membrana mediante exposición de la misma a luz UV durante 2 minutos. Finalmente, la membrana se secó al vacío durante 2 horas a $80^{\circ} \mathrm{C}$, quedando preparada para la etapa de hibridización.

\section{c) Preparación de sondas marcadas con [a-32P]dCTP $e$ hibridización.}

Para preparar las diferentes sondas se partió del ADNc de las enzimas SCD1, $\Delta 6$ y $\Delta 5$ desaturasas de rata (GenBank accession numbers NM_139192 AB021980 y AF320509, respectivamente) (donados por Dr. Juris Ozols - University of Connecticut, Farmington, E.E.U.U.; Dr. Tsuneiro Aki - Hiroshima University, Hiroshima, Japón; y Dr. Reza Zolfaghari y Dra. Catharine Ross - Pennsylvania State University Pennsylvania, E.E.U.U., respectivamente). El ADNc de SCD1 contenido en el plásmido pUC8 se extrajo con las enzimas de restricción EcoRI/BamHI, y el segmento de 1065 pbs obtenido constituyó el molde para la preparación de la sonda marcada radiactivamente. En el caso de la sonda para $\Delta 6$ desaturasa, el molde para su preparación se obtuvo al extraer el ADNc de la enzima desde el vector Lambda ZapII (Stratagene), cortando con las enzimas de restricción EcoRI/XhoI, lo que dio lugar a dos fragmentos de 885 y 835 pbs. Para la $\Delta 5$ desaturasa, se obtuvo el molde para preparación de la sonda mediante amplificación por PCR de 
un fragmento del ADNc de la enzima, contenido en el vector pCDNA3.1 (Invitrogen), utilizando los siguientes cebadores:

directo: 5'-ACCAAGAATAAGGCGCTCAC inverso: 5'-GAACTGTACTGAGCAGCACT

Para normalizar la cantidad de ARN sembrado para cada una de las muestras, se utilizó una sonda contra la proteína $\beta$ actina.

Una vez obtenidos los moldes, se procedió a la preparación de las sondas marcadas propiamente dichas. Para ello se utilizó el kit Prime a Gene Labeling System (Promega) siguiendo las instrucciones del fabricante, utilizando $50 \mu \mathrm{Ci}$ de [a-32P]dCTP (Amersham Biosciences) cada $25 \mathrm{ng}$ de ADN molde. La incubación se realizó durante 2 horas a $23^{\circ} \mathrm{C}$ en baño termostático. Al finalizar la incubación, se purificó la sonda recién preparada mediante el kit Wizard DNA Clean-up System (Promega) según el protocolo del fabricante.

Mientras transcurría la preparación de la sonda radiactiva, se procedió a pre-hibridizar la membrana con el ARN transferido y seco. Para ello se incubó la misma en solución de pre-hibridización (2,5 ml de formamida (JT Baker Ultrapura); Fosfato de $\mathrm{Na} \mathrm{pH} \mathrm{7,2} \mathrm{0,12} \mathrm{M;} \mathrm{NaCl}$ 0,25 M; SDS 7\% p/p; EDTA pH $81 \mathrm{mM}$; reactivo de Denhart 1X (2,5 g\% de Ficoll, 2,5 g\% de Polivivilpirrolidona y 2,5 g\% de BSA); ADN de esperma de salmón $0,1 \mathrm{mg} / \mathrm{ml}$ ) a $43^{\circ} \mathrm{C}$ durante 1,5 horas, en horno de hibridización.

Por último se descartó la solución de pre-hibridización y se reemplazo por solución de hibridización, cuya composición es la misma que la de pre-hibridización salvo que la anterior posee además la sonda marcada, la cual se desnaturalizó por calor antes de su agregado. Se incubó en horno de hibridización a $43^{\circ} \mathrm{C}$ durante $12-18$ horas. 


\section{d) Revelado de la señal radiactiva.}

Para revelar las señales correspondientes a los distintos ARN, la membrana se quitó de la solución de hibridización, se lavó durante 30 minutos por vez, de manera sucesiva, con buffer SSC 2X/SDS 0,1\% $\mathrm{p} / \mathrm{v}, \operatorname{SSC} 0,5 \mathrm{X} / \mathrm{SDS} 0,1 \% \mathrm{p} / \mathrm{v}$ y SSC $0,1 \mathrm{X} / \mathrm{SDS} 0,1 \% \mathrm{p} / \mathrm{v}$ y se colocó dentro de bolsas de nylon especialmente selladas. Así preparada, la membrana se puso dentro del casete de exposición de un aparato PhosphorImager (Molecular Dynamics), y luego de un tiempo de exposición de 6-48 horas, se escaneó su imagen y se procedió a la cuantificación de la intensidad emitida por cada banda. Los resultados se expresan como intensidades relativas normalizadas en base a la intensidad de señal para $\beta$-actina. 


\section{H ANALISIS ESTADISTICO}

Los resultados se expresan como media \pm SD. Las diferencias estadísticamente significativas entre los distintos grupos se calcularon utilizando el método ANOVA (Instant V. 2.0 Graph. Pad. Software). Se utilizó la prueba de comparación múltiple de Turkey-Kramer. La significancia estadística se definió como $P<0,05$. 


\section{III - RESULTADOS}

Los diversos experimentos planificados cuyos resultados se presentan a continuación tienen por objeto aclarar sucesivamente los efectos moduladores independientes y combinados de factores como la insulina, el PPAR- $\alpha$, el LXR- $\alpha$ y el SREBP-1c sobre la expresión y actividad de SCD1, $\Delta 6$ y $\Delta 5$ desaturasas hepáticas y sobre sus efectos en la composición lipídica de hígado y membranas microsomales.

\section{A Efectos de Insulina y Fenofibrato Sobre Animales Diabéticos de Tipo I}

Para estudiar el efecto de la diabetes mellitus de tipo I sobre la expresión de las desaturasas hepáticas, así como también la influencia de la activación de la vía dependiente de PPAR-a sobre el metabolismo de estas enzimas, se utilizaron ratas Wistar a las que se provocó diabetes por deficiencia de insulina mediante inyección de STZ. Posteriormente, una parte de los animales diabéticos recibió tratamiento con insulina Glargina durante 9 días consecutivos. Se reservaron controles de animales no diabéticos, y diabéticos pero sin tratamiento insulínico. Por último, una parte de cada uno de los tres lotes antes obtenidos, no diabéticos (nd), diabéticos (d) y diabéticos más insulina $(\mathrm{d}+\mathrm{i})$, recibió Fen, conocido activador especifico de PPAR-a, durante 9 días, por administración oral junto a la dieta normal. 
Así diseñados, estos experimentos se utilizaron para evaluar los efectos de la patología diabética y de los diferentes tratamientos sobre la expresión y actividad de las desaturasas. Asimismo, sirvieron para estudiar la interacción entre las distintas vias regulatorias del metabolismo de estas enzimas.

\section{Parámetros plasmáticos}

En la Tabla III.1, se muestran los cambios en los parámetros plasmáticos producidos por la administración de Fen durante nueve días, en ratas no diabéticas (nd), diabéticas por estreptozotocina (d) y diabéticas tratadas con insulina $(\mathrm{d}+\mathrm{i})$, evaluados 24 horas luego de la última administración de la hormona y de fenofibrato.

El Fen fue capaz de incrementar la insulinemia, pero solamente en animales nd, no produciendo ningún cambio sobre este parámetro en los animales $\mathrm{d}$ ni en los $\mathrm{d}+\mathrm{i}$, demostrando un efecto específico sobre el lote de animales con el páncreas intacto.

Tabla III. 1: Parámetros plasmáticos

\begin{tabular}{|c|c|c|c|c|c|c|}
\hline \multirow{2}{*}{} & \multicolumn{2}{|c|}{ No diabéticas } & \multicolumn{2}{c|}{ Diabéticas } & \multicolumn{2}{c|}{ Diabéticas + insulina } \\
\cline { 2 - 7 } & Fen (a) & + Fen (b) & - Fen(c) & + Fen (d) & - Fen (e) & +Fen (f) \\
\hline $\begin{array}{c}\text { Insulinemia } \\
(\mathrm{ng} / \mathrm{ml})\end{array}$ & $1,50 \pm 0,88$ & $\begin{array}{c}13,29 \pm 4,18 \\
\mathrm{a} * * *\end{array}$ & $0,18 \pm 0,14$ & $\begin{array}{c}0,26 \pm 0,28 \\
\mathrm{~b} * * *\end{array}$ & $\begin{array}{c}0,14 \pm 0,04 \\
\mathrm{~b}_{* * *}\end{array}$ & $\begin{array}{c}0,24 \pm 0,08 \\
\mathrm{~b}_{* * *}\end{array}$ \\
\hline $\begin{array}{c}\text { Glucemia } \\
(\mathrm{mg} / \mathrm{dl})\end{array}$ & $129,03 \pm 28,34$ & $122,55 \pm 7,47$ & $\begin{array}{c}424,13 \pm 94,36 \\
\mathrm{a}_{* *} \mathrm{~b}_{* *}\end{array}$ & $\begin{array}{c}553,20 \pm 31,78 \\
\mathrm{~b}_{* * *}\end{array}$ & $\begin{array}{c}554,48 \pm 90,55 \\
\mathrm{a}_{* * *}\end{array}$ & $503,88 \pm 184,23$ \\
\hline $\begin{array}{c}\text { Colesterolemia } \\
(\mathrm{mg} / \mathrm{dl})\end{array}$ & $50,73 \pm 3,05$ & $33,60 \pm 4,93$ & $45,73 \pm 19,01$ & $50,33 \pm 2,96$ & $57,60 \pm 9,71$ & $66,68 \pm 12,22$ \\
\hline
\end{tabular}

Las ratas $\mathrm{nd}, \mathrm{d}$ y $\mathrm{d}+\mathrm{i}$ se alimentaron diariamente con fenofibrato (Fen) y se inyectaron con insulina glargina durante 9 dias en los casos especificados, como se describió en Metodología. Los parámetros se midieron luego de $12 \mathrm{hr}$ de ayuno y $24 \mathrm{hr}$ luego de la última administración de insulina y/o fenofibrato. Los resultados son la media \pm SD (4 animales) analizados por ANOVA. Las diferentes letras superindices indican diferencias entre este valor y el del grupo encabezado por esa letra. ${ }^{* * *} \mathrm{P}<0,001$, ** $\mathrm{P}<0,01$ 
La insulinemia, a las 24 hs luego del último tratamiento con hormona, se encontró disminuida no solo en los animales diabéticos, sino también en los animales tratados con insulina glargina. Este resultado, junto con el hecho de que la glucemia (medida a las 24 hs post inyección de insulina) estuvo aumentada tanto en los animales diabéticos como en los diabéticos tratados con insulina, demuestra que el efecto hiperinsulinémico provocado por la administración de hormona, así como la concomitante disminución de la glucemia que se debería observar no son detectados a las 24 horas luego de la administración hormonal, indicando que la duración del efecto de la insulina que se administró fue menor a 24 horas.

Para comprobar si la hormona administrada estaba produciendo algún efecto, se midió la glucemia 4 horas luego de la administración de insulina (Tabla III.2), observándose una disminución significativa de la misma en el grupo tratado con la hormona, en comparación con los animales diabéticos sin tratamiento, lo que demuestra que el efecto de la administración de insulina Glargina sobre la glucemia existe, pero su acción decae antes de las 24 horas.

Tabla III.2: Glucemia medida luego de 4 horas de la última inyección de insulina

\begin{tabular}{|c|c|c|c|c|c|}
\hline \multicolumn{2}{|c|}{ No diabéticas } & \multicolumn{2}{c|}{ Diabéticas } & \multicolumn{2}{c|}{ Diabéticas + insulina } \\
\hline -Fen (a) & + Fen (b) & - Fen (c) & + Fen (d) & - Fen (e) & + Fen (f) \\
\hline $121,7 \pm 13,0$ & $117,8 \pm 14,5$ & $491,9 \pm 16,1^{\mathrm{a} * * *}$ & $439,5 \pm 15,4^{\mathrm{b} * * *}$ & $123,1 \pm 8,0^{\mathrm{c} * * *}$ & $55,9 \pm 10,3^{\mathrm{d} * * *} *_{* * *}$ \\
\hline
\end{tabular}

Los resultados se expresan en $\mathrm{mg} / \mathrm{dl}$ de la media \pm SD de 4 animales. La significancia estadistica se analizó por ANOVA. $\mathrm{P}<0.001 * * *$

El Fen también produjo una disminución de la glucemia en los animales $(\mathrm{d}+\mathrm{i}), 4$ horas después de la administración de insulina (Tabla 
III.2), en concordancia con su efecto estimulador de la insulinemia ya observado en la Tabla III.1.

\section{Efectos del Fen sobre el hígado}

El Fen produjo un aumento de la relación peso de hígado a peso corporal en las ratas no diabéticas (de 0,037 $\pm 0,002$ a 0,045 $\pm 0,003$ ), en los animales diabéticos (de 0,040 $\pm 0,002$ a 0,047 $\pm 0,001$ ) y en las ratas diabéticas tratadas con insulina (de 0,061 \pm 0,011 a 0,067 \pm 0,006). Esto demuestra el efecto hepatomegálico típico de la activación de PPAR-a por parte del fenofibrato.

Efecto sobre Acil-CoA oxidasa peroxisomal hepática

Una de las enzimas blanco de PPAR-a más reconocidas, y cuya actividad se suele utilizar como medida de activación de la vía dependiente de este factor de transcripción, es la acil-CoA oxidasa extramitocondrial o peroxisomal. Para comprobar entonces si la administración de Fen estaba activando en forma efectiva esta vía, se realizó la medida de actividad enzimática de acil-CoA peroxisomal hepática, en donde se encontró que el Fen produjo un aumento de este parámetro (Tabla III.3) en todos los grupos estudiados, demostrando de esta forma, junto a la hepatomegalia antes mencionada, una activación de la vía dependiente de PPAR-a.

Tabla III.3: Actividad de acil-CoA oxidasa peroxisomal hepática (nmoles/min.mg prot)

\begin{tabular}{|c|c|c|c|c|c|}
\hline \multicolumn{2}{|c|}{ No diabéticas } & \multicolumn{2}{c|}{ Diabéticas } & \multicolumn{2}{c|}{ Diabéticas + insulina } \\
\hline -Fen (a) & + Fen (b) & - Fen (c) & + +Fen (d) & - Fen (e) & + +Fen (f) \\
\hline $5,34 \pm 0,60$ & $42,63 \pm 2,47^{\mathrm{a} * * *}$ & $9,79 \pm 2,16$ & $49,55 \pm 3,64^{\mathrm{c} * * *}$ & $4,37 \pm 0,84^{\mathrm{c} * \mathrm{~d} * * *}$ & $29,92 \pm 2,39^{\mathrm{c} * * * \mathrm{~d}_{*} * * \mathrm{e}_{* * *}}$ \\
\hline
\end{tabular}

Los resultados son la media \pm SD de 4 animales. La significancia estadística se analizó mediante ANOVA. ${ }^{* * *} \mathrm{P}<0,001,{ }^{*} \mathrm{P}<0,1$ 
Expresión y actividad de las desaturasas hepáticas

La Fig. III.1 ilustra el conocido efecto depresor de la diabetes sobre el ARNm de SCD1 (Waters, KM y Ntambi, JM, 1994) y también sobre el de la $\Delta 5$ desaturasa hepática, los que se recuperaron con el tratamiento con insulina durante 9 dias, indicando que la hormona, a pesar de no tener una duración en su efecto (evidenciado en la medida de glucemia) durante 24 horas, la administración diaria de la misma durante 9 dias fue capaz de producir una inducción de la expresión de SCD1 y $\triangle 5$ desaturasa.

Por otra parte, el Fen incrementó fuertemente el nivel de los mismos ARNs tanto en los animales nd como en los $d+i$, con un mayor efecto sobre la expresión de SCD1. En los animales d, el efecto provocado por Fen no llegó a ser estadísticamente significativo.

Fig. III. 1: Efecto de Fen en ratas no diabéticas (nd), diabéticas (d) y diabéticas tratadas con insulina $(\mathrm{d}+\mathrm{i})$ sobre el nivel de ARNm de SCD1 y $\Delta 5$ desaturasa.

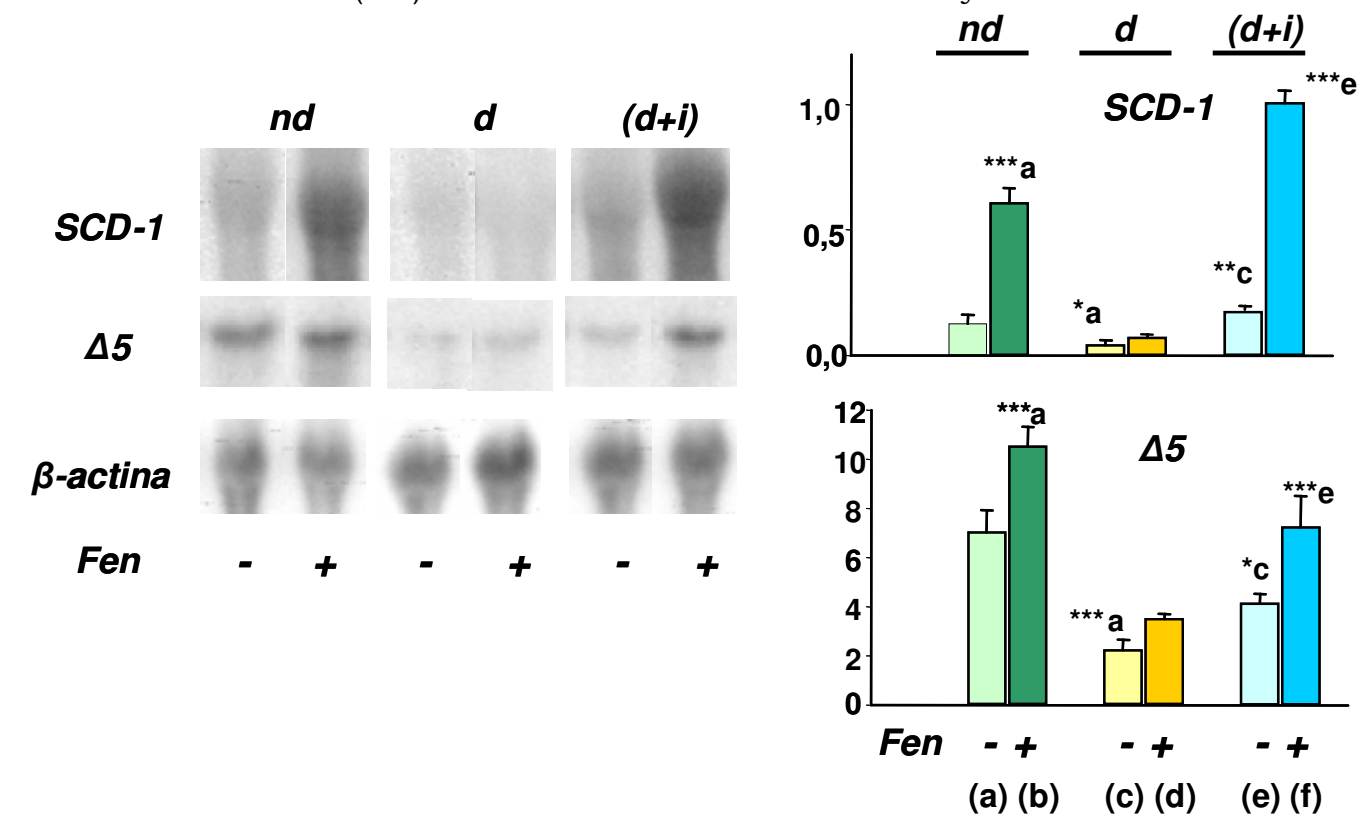

Los ARNm se trataron como se describió en Metodología y se cuantificaron usando un equipo PhosphorImager (Molecular Dynamics). Los resultados se expresan como unidades arbitrarias de la media \pm SD para 4 animales, analizados por ANOVA Las diferentes letras superindices indican diferencias entre este valor y el del grupo encabezado por la letra. ${ }^{* * *} P<0,001,{ }^{* *} P<0,01,{ }^{*} P<0,05$, los signos +0 - indican la presencia o ausencia de Fen. 
En la Tabla III.4 se puede observar el comportamiento de la actividad de las desaturasas hepáticas $\Delta 5$ y $\Delta 9$ (al hablar de la actividad de esta enzima nos referiremos a la misma como $\Delta 9$, la que posee dos isoformas, de las cuales la mayoritaria, en hígado, corresponde a SCD1, cuyo ARNm es el que se mide en todos los casos), ya encontrado anteriormente en otros trabajos (Brenner, RR y col., 2000). Se encontró que estos valores de actividad se deprimen como consecuencia de la diabetes, recuperándose los mismos por medio del tratamiento con insulina.

La ingesta de Fen incrementó estas actividades enzimáticas en animales $\mathrm{nd}, \mathrm{d}$ y $\mathrm{d}+\mathrm{i}$, hecho consistente con lo encontrado en la medida de los ARNm. Por lo tanto, se puede ver que tanto el Fen como la insulina activan la expresión y actividad de la $\Delta 5$ desaturasa y de la SCD1, y que además lo pueden hacer de manera independiente.

Tabla III.4: Actividad desaturante $\Delta 9$ y $\Delta 5$ (nmoles $/$ min.mg prot)

\begin{tabular}{|c|c|c|c|c|c|c|}
\hline & \multicolumn{2}{|c|}{ No diabéticas } & \multicolumn{2}{|c|}{ Diabéticas } & \multicolumn{2}{|c|}{ Diabéticas + insulina } \\
\hline Desaturasa & -Fen (a) & +Fen (b) & - Fen (c) & $+\operatorname{Fen}(d)$ & - Fen (e) & +Fen (f) \\
\hline$\Delta \mathbf{9}$ & $0,032 \pm 0,003$ & $\begin{array}{l}0,142 \pm 0,023 \\
a_{* * *}\end{array}$ & ND & $\begin{array}{l}0,057 \pm 0,014 \\
\mathrm{c}_{* * *}\end{array}$ & $\begin{array}{l}0,204 \pm 0,054 \\
\mathrm{c}_{* * *} \mathrm{~d}_{* * *}\end{array}$ & $\begin{array}{l}0,276 \pm 0,015 \\
\mathrm{c}_{* * *} \mathrm{~d}_{* * *} \mathrm{e}_{* *}\end{array}$ \\
\hline$\Delta 5$ & $0,123 \pm 0,029$ & $\begin{array}{l}0,200 \pm 0,015 \\
\mathrm{a}_{*}\end{array}$ & $0,047 \pm 0,010^{\mathrm{a}} *$ & $\begin{array}{l}0,159 \pm 0,031 \\
\mathrm{c}_{* * *}\end{array}$ & $\begin{array}{l}0,135 \pm 0,017 \\
\text { c }_{* *}\end{array}$ & $\begin{array}{l}0,301 \pm 0,052 \\
\mathrm{c}_{* * * *} \mathrm{~d}_{* * *} \mathrm{e}_{* * *}\end{array}$ \\
\hline
\end{tabular}

Los resultados son la media \pm SD de 4 animales, ND: no detectado. La significancia estadística se analizó mediante ANOVA. *** $\mathrm{P}<0,001,{ }^{* *} \mathrm{P}<0,01,{ }^{*} \mathrm{P}<0,1$

Estudio de composiciones de ácidos grasos de membrana

Las Tablas III.5, 6 y 7 describen las modificaciones producidas por la diabetes y por los tratamientos con insulina y Fen en las composiciones de ácidos grasos de las fracciones microsomal, fosfatidilcolina microsomal y homogenato total hepáticas.

En todas las fracciones lipídicas investigadas se observó que la diabetes produjo una disminución simultánea de los ácidos palmitoleico 
(16:1) y oleico (18:1n-9), a causa de la disminución de actividad de $\Delta 9$ desaturasa, en comparación con los animales control sanos, aunque estos cambios solamente fueron significativos en la composición de ácidos grasos de homogenato hepáticos (Tabla III.7). En el resto de los casos solamente fue significativa la disminución del ácido palmitoleico (16:1) (Tablas III.5 y 6).

De todos modos, todas las clases de lipidos estudiados mostraron una disminución de los cocientes 16:1/16:0 y 18:1n-9/18:0 (los que se pueden utilizar como medida aproximada de la actividad $\Delta 9$ desaturante debido a que son, en cada caso, los cocientes producto/sustrato) en las ratas diabéticas, comparadas con animales no diabéticos, y una recuperación de los mismos parámetros al tratar los animales diabéticos con insulina (Tablas III.5 a 7), siendo estos cambios correspondientes con lo encontrado para los niveles de ARNm y la actividad de SCD1.

Tabla III.5: Composición de ácidos grasos de microsomas hepáticos

\begin{tabular}{|c|c|c|c|c|c|c|}
\hline \multirow[b]{2}{*}{$\mathbf{A G}$} & \multicolumn{2}{|c|}{ No Diabéticas } & \multicolumn{2}{|c|}{ Diabéticas } & \multicolumn{2}{|c|}{ Diabéticas + insulina } \\
\hline & $\begin{array}{c}\text {-Fen } \\
\text { (a) }\end{array}$ & $\begin{array}{c}+ \text { Fen } \\
\text { (b) }\end{array}$ & $\begin{array}{c}- \text { Fen } \\
\text { (c) }\end{array}$ & $\begin{array}{c}+ \text { Fen } \\
\text { (d) }\end{array}$ & $\begin{array}{c}\text { - Fen } \\
\text { (e) }\end{array}$ & $\begin{array}{c}+ \text { Fen } \\
\text { (f) }\end{array}$ \\
\hline 16:0 & $17,42 \pm 0,76$ & $25,44 \pm 0,78^{\mathrm{a}^{* * * *}}$ & $17,40 \pm 0,75$ & $23,65 \pm 1,43^{\mathrm{c}^{* * * *}}$ & $21,48 \pm 1,75^{\mathrm{c}^{* *}}$ & $24,14 \pm 1,13^{\mathrm{c}^{* * *} \mathrm{c}}$ \\
\hline 16:1 & $0,58 \pm 0,16$ & $0,63 \pm 0,10$ & $0,29 \pm 0,10^{\mathrm{a}^{*}}$ & $0,27 \pm 0,12^{b^{* *}}$ & $0,49 \pm 0,11$ & $0,71 \pm 0,07^{\mathrm{c} * * *} \mathrm{~d}^{* * *}$ \\
\hline 18:0 & $24,91 \pm 1,12$ & $20,45 \pm 2,06^{\mathrm{a}^{* *}}$ & $27,83 \pm 0,60$ & $22,66 \pm 1,67^{\mathrm{c}^{* * *}}$ & $23,80 \pm 1,60^{\mathrm{c}^{* *}}$ & $20,24 \pm 1,01^{\mathrm{c}^{* * * *} \mathrm{e}^{*}}$ \\
\hline 18:1n-9 & $6,82 \pm 1,22$ & $8,24 \pm 1,33$ & $5,02 \pm 0,52$ & $6,02 \pm 0,70$ & $6,40 \pm 0,98$ & $8,84 \pm 0,95^{\mathrm{c} * * *} \mathrm{~d}^{* * * *} \mathrm{e}^{*}$ \\
\hline $18: 2 n-6$ & $14,64 \pm 1,50$ & $14,00 \pm 1,22$ & $11,80 \pm 1,40$ & $11,56 \pm 0,60$ & $13,97 \pm 1,09$ & $11,43 \pm 1,77^{\mathrm{d}^{*}}$ \\
\hline $20: 3 n-6$ & $0,95 \pm 0,12$ & $1,52 \pm 0,13$ & $0,86 \pm 0,20$ & $0,96 \pm 0,21$ & $1,39 \pm 0,44$ & $2,20 \pm 0,29^{\mathrm{c} * * * \mathrm{~d}^{* * * *}} \mathrm{e}^{* *}$ \\
\hline $20: 4 n-6$ & $24,94 \pm 2,04$ & $23,82 \pm 1,40$ & $21,84 \pm 1,51$ & $19,42 \pm 0,91$ & $20,68 \pm 2,04$ & $21,86 \pm 2,29$ \\
\hline $22: 6 n-3$ & $5,23 \pm 0,45$ & $4,04 \pm 0,40$ & $11,89 \pm 1,16^{\mathrm{a}^{* * * *}}$ & $12,69 \pm 1,72$ & $8,50 \pm 1,01^{\mathrm{c}^{* *}}$ & $7,98 \pm 1,38^{\mathrm{c} * *} \mathrm{~d}^{* * * *}$ \\
\hline 16:1/16:0 & $0,033 \pm 0,008$ & $0,025 \pm 0,003$ & $0,017 \pm 0,005$ & $0,011 \pm 0,005$ & $0,023 \pm 0,004$ & $0,030 \pm 0,004$ \\
\hline 18:1/18:0 & $0,276 \pm 0,062$ & $0,410 \pm 0,095$ & $0,181 \pm 0,020$ & $0,268 \pm 0,044$ & $0,271 \pm 0,053$ & $0,437 \pm 0,040$ \\
\hline 20:4/18:2 & $1,724 \pm 0,282$ & $1,716 \pm 0,243$ & $1,880 \pm 0,331$ & $1,682 \pm 0,079$ & $1,490 \pm 0,216$ & $1,971 \pm 0,519$ \\
\hline $20: 4 / 20: 3$ & $26,69 \pm 5,30$ & $15,78 \pm 1,78$ & $26,77 \pm 8,31$ & $20,76 \pm 3,38$ & $15,85 \pm 4,42$ & $10,03 \pm 1,18$ \\
\hline
\end{tabular}

Los resultados se expresan como \% en peso y son la media \pm SD de 4 animales. Con los ácidos grasos minoritarios se llega al 100\%.La significancia estadística se analizó mediante ANOVA ${ }^{* * *} \mathrm{P}<0,001,{ }^{* *} \mathrm{P}<0,01,{ }^{*} \mathrm{P}<0,1$ 
El Fen no provocó efectos significativos (Tablas III.5 a 7) sobre los niveles de ácidos monoenoicos, excepto en las fracciones lipídicas de los animales $d+i$. Sin embargo, el cociente 18:1n-9/18:0 mostró un aumento a causa del Fen en todos los lipidos estudiados tanto en las ratas no diabéticas como en las diabéticas tratadas con insulina (Tablas III.5 a 7). El incremento de este cociente, que se suele asociar con un incremento de actividad de $\Delta 9$ desaturasa, pierde importancia cuando se comprueba que dicha variación se debe casi exclusivamente a una disminución de ácido esteárico (denominador), lo cual invalida, en este caso, la asociación del aumento del cociente con un posible aumento actividad $\Delta 9$ desaturasa.

En el caso de la familia de ácidos grasos n-6, ni la insulina ni el fenofibrato produjeron cambios sobre los niveles de ácido araquidónico ni sobre el cociente 20:4n-6/18:2n-6 (utilizado como medida aproximada de los niveles de actividad $\Delta 5$ y $\Delta 6$ desaturante combinadas). Solamente el ácido eicosa-8,11,14-trienoico (20:3n-6) aumentó en todos los animales y en todos los lípidos como consecuencia de la administración de fenofibrato.

Por otro lado, las Tablas III.5 a 7 reflejan que el porcentaje de ácido docosa-4,7,10,13,16,19-hexenoico (22:6n-3) de la serie n-3 se modificó fuertemente como causa de la diabetes (aumentó) y de la insulina (disminuyó a valores casi normales), pero no mostró efectos ante la administración de Fen, como generalmente se encuentra, lo cual no es correlativo con los cambios en la $\Delta 5$ desaturasa.

Por último, se debe remarcar el hecho de que el Fen produjo, en todos los lotes estudiados y en todos los lipidos investigados, un incremento importante de ácido palmítico (16:0) acompañado por una marcada disminución de ácido esteárico (18:0). 
Tabla III.6: Composición de ácidos grasos de fosfatidilcolina de lípidos microsomales

\begin{tabular}{|c|c|c|c|c|c|c|}
\hline & \multicolumn{2}{|c|}{ No diabéticas } & \multicolumn{2}{|c|}{ Diabéticas } & \multicolumn{2}{|c|}{ Diabéticas + insulina } \\
\hline $\mathbf{A G}$ & $\begin{array}{c}\text {-Fen } \\
\text { (a) }\end{array}$ & $\begin{array}{c}+ \text { Fen } \\
\text { (b) }\end{array}$ & $\begin{array}{c}- \text { Fen } \\
\text { (c) }\end{array}$ & $\begin{array}{c}+ \text { Fen } \\
\text { (d) }\end{array}$ & $\begin{array}{c}- \text { Fen } \\
\text { (e) }\end{array}$ & $\begin{array}{c}+ \text { Fen } \\
\text { (f) }\end{array}$ \\
\hline 16:0 & $20,59 \pm 1,40$ & $33,69 \pm 1,41^{a^{* * * *}}$ & $21,09 \pm 1,18$ & $31,09 \pm 1,56^{\mathrm{c}^{* * *}}$ & $26,90 \pm 3,14^{\mathrm{c}^{* *}}$ & $32,94 \pm 1,35^{\mathrm{c}^{* * * *} \mathrm{e}^{* *}}$ \\
\hline 16:1 & $0,55 \pm 0,12$ & $0,57 \pm 0,05$ & $0,20 \pm 0,14^{\mathrm{a}^{*}}$ & $0,20 \pm 0,15$ & $0,44 \pm 0,03$ & $0,40 \pm 0,27$ \\
\hline 18:0 & $25,29 \pm 2,88$ & $13,84 \pm 0,99^{a^{* * *}}$ & $25,84 \pm 0,90$ & $16,55 \pm 1,30^{\mathrm{c}^{* * * *}}$ & $21,79 \pm 1,75^{\mathrm{c}^{*}}$ & $14,27 \pm 1,21^{\mathrm{c}^{* * * *} \mathrm{e}^{* * * *}}$ \\
\hline 18:1n-9 & $7,42 \pm 2,32$ & $10,25 \pm 1,36$ & $6,29 \pm 1,30$ & $7,92 \pm 1,53$ & $9,10 \pm 2,79$ & $11,64 \pm 2,33^{\mathrm{c}^{* *} \mathrm{~d}^{* * *} \mathrm{e}^{* * *}}$ \\
\hline $18: 2 n-6$ & $15,32 \pm 0,84$ & $16,90 \pm 1,35$ & $13,10 \pm 1,31$ & $14,68 \pm 0,99$ & $16,62 \pm 1,62^{\mathrm{c}^{* *}}$ & $14,43 \pm 1,26$ \\
\hline $20: 3 n-6$ & $0,80 \pm 0,14$ & $1,33 \pm 0,09^{\mathrm{a}^{* * *}}$ & $0,55 \pm 0,09$ & $0,69 \pm 0,13$ & $0,88 \pm 0,10^{c^{*}}$ & $2,13 \pm 0,25^{\mathrm{c}^{* * * *}}$ \\
\hline $20: 4 n-6$ & $24,34 \pm 1,14$ & $20,72 \pm 2,03$ & $20,18 \pm 1,77$ & $17,25 \pm 3,11$ & $17,97 \pm 3,85$ & $19,40 \pm 0,95$ \\
\hline $22: 6 n-3$ & $4,12 \pm 0,49$ & $2,51 \pm 0,32$ & $11,38 \pm 1,07^{\mathrm{a}^{* * * *}}$ & $10,38 \pm 2,68$ & $5,61 \pm 1,61^{\mathrm{c}^{* * *}}$ & $4,48 \pm 2,04^{\mathrm{c} * * *} \mathrm{~d}^{* * *}$ \\
\hline 16:1/16:0 & $0,027 \pm 0,005$ & $0,017 \pm 0,002$ & $0,009 \pm 0,006$ & $0,006 \pm 0,005$ & $0,016 \pm 0,003$ & $0,012 \pm 0,008$ \\
\hline 18:1/18:0 & $0,304 \pm 0,119$ & $0,747 \pm 0,146$ & $0,245 \pm 0,058$ & $0,487 \pm 0,135$ & $0,425 \pm 0,160$ & $0,815 \pm 0,143$ \\
\hline 20:4/18:2 & $1,593 \pm 0,118$ & $1,237 \pm 0,210$ & $1,554 \pm 0,223$ & $1,180 \pm 0,231$ & $1,102 \pm 0,322$ & $1,355 \pm 0,167$ \\
\hline $20: 4 / 20: 3$ & $31,20 \pm 6,65$ & $15,58 \pm 1,62$ & $37,72 \pm 8,00$ & $25,20 \pm 3,30$ & $20,75 \pm 6,20$ & $9,17 \pm 0,82$ \\
\hline
\end{tabular}

Tabla III.7: Composición de ácidos grasos de homogenato hepático

\begin{tabular}{|c|c|c|c|c|c|c|}
\hline \multirow[b]{2}{*}{$\mathbf{A G}$} & \multicolumn{2}{|c|}{ No diabéticas } & \multicolumn{2}{|c|}{ Diabéticas } & \multicolumn{2}{|c|}{ Diabéticas + insulina } \\
\hline & $\begin{array}{c}\text {-Fen } \\
\text { (a) }\end{array}$ & $\begin{array}{c}\text { +Fen } \\
\text { (b) }\end{array}$ & $\begin{array}{c}\text { - Fen } \\
\text { (c) }\end{array}$ & $\begin{array}{c}+ \text { Fen } \\
\text { (d) }\end{array}$ & $\begin{array}{c}\text { - Fen } \\
\text { (e) }\end{array}$ & $\begin{array}{c}+ \text { Fen } \\
\text { (f) }\end{array}$ \\
\hline 16:0 & $17,43 \pm 0,88$ & $24,39 \pm 0,41^{\mathrm{a}^{* * *}}$ & $17,00 \pm 0,17$ & $21,78 \pm 0,73^{\mathrm{c} * * *}$ & $19,72 \pm 0,88^{\mathrm{c}^{* *}}$ & $22,32 \pm 1,20^{\mathrm{c} * * * \mathrm{e}^{* * *}}$ \\
\hline 16:1 & $0,75 \pm 0,11$ & $0,74 \pm 0,08$ & $0,07 \pm 0,15^{\mathrm{a}^{* * *}}$ & $0,27 \pm 0,03$ & $0,49 \pm 0,11^{\mathrm{c}^{* * * *}}$ & $0,81 \pm 0,11^{\mathrm{c}^{* * *} \mathrm{~d}^{* * * *} \mathrm{e}^{* *}}$ \\
\hline 18:0 & $19,98 \pm 0,71$ & $17,44 \pm 0,58^{\mathrm{a}^{* *}}$ & $25,85 \pm 0,40^{\mathrm{a}^{* * * *}}$ & $21,18 \pm 1,03^{\mathrm{c} * * *}$ & $21,16 \pm 0,95^{\mathrm{c}^{* * * *}}$ & $18,07 \pm 0,38^{\mathrm{c} * * *} \mathrm{~d}^{* * * *} \mathrm{e}^{* * * *}$ \\
\hline 18:1n-9 & $10,43 \pm 1,09$ & $11,94 \pm 1,35$ & $4,74 \pm 0,42^{\mathrm{a}^{* * * *}}$ & $5,65 \pm 0,38$ & $6,74 \pm 0,89$ & $11,09 \pm 2,15^{\mathrm{c} * * * \mathrm{~d}^{* * *} \mathrm{e}^{* * * *}}$ \\
\hline $18: 2 n-6$ & $19,51 \pm 1,40$ & $17,35 \pm 0,87$ & $15,59 \pm 1,03^{\mathrm{a}^{* *}}$ & $15,09 \pm 0,27$ & $17,61 \pm 1,27$ & $14,99 \pm 1,39^{\mathrm{e}^{*}}$ \\
\hline $20: 3 n-6$ & $0,90 \pm 0,13$ & $1,48 \pm 0,14^{\mathrm{a}^{*}}$ & $0,83 \pm 0,16$ & $0,91 \pm 0,17$ & $1,30 \pm 0,39$ & $2,14 \pm 0,20^{\mathrm{c} * * * * \mathrm{~d}^{* * * *} \mathrm{e}^{* * * *}}$ \\
\hline $20: 4 n-6$ & $20,58 \pm 0,87$ & $20,64 \pm 1,14$ & $19,64 \pm 1,10$ & $17,86 \pm 1,07$ & $18,23 \pm 0,67$ & $19,35 \pm 1,51$ \\
\hline $22: 6 n-3$ & $5,17 \pm 0,48$ & $3,89 \pm 0,36$ & $12,46 \pm 0,93^{\mathrm{a}^{* * * *}}$ & $13,48 \pm 1,21$ & $10,25 \pm 1,48$ & $8,05 \pm 1,37^{\mathrm{c***} \mathrm{d}^{* * * *}}$ \\
\hline 16:1/16:0 & $0,043 \pm 0,007$ & $0,030 \pm 0,004$ & $0,004 \pm 0,009$ & $0,013 \pm 0,002$ & $0,025 \pm 0,005$ & $0,036 \pm 0,006$ \\
\hline 18:1/18:0 & $0,524 \pm 0,075$ & $0,686 \pm 0,093$ & $0,184 \pm 0,018$ & $0,268 \pm 0,030$ & $0,321 \pm 0,057$ & $0,614 \pm 0,121$ \\
\hline 20:4/18:2 & $1,060 \pm 0,098$ & $1,193 \pm 0,119$ & $1,267 \pm 0,145$ & $1,183 \pm 0,059$ & $1,040 \pm 0,104$ & $1,307 \pm 0,236$ \\
\hline $20: 4 / 20: 3$ & $23,38 \pm 4,00$ & $14,07 \pm 1,52$ & $24,60 \pm 6,00$ & $20,01 \pm 2,85$ & $14,90 \pm 4,10$ & $9,10 \pm 0,84$ \\
\hline
\end{tabular}

Para ambas Tablas (Tabla III.6 y 7), los resultados se expresan como \% e peso y son la media \pm SD de 4 animales. Los ácidos grasos minoritarios, no incluidos, hacen el $100 \%$. La significancia estadística se analizó mediante ANOVA. ${ }^{* *} \mathrm{P}<0,001,{ }^{* *} \mathrm{P}<0,01$, * $\mathrm{P}<0,1$ 


\section{B Efectos de Insulina, Fenofibrato y T091317 Sobre Animales Diabéticos de Tipo I}

Para ampliar lo investigado en el tramo anterior del trabajo, se realizó un estudio en animales Wistar diabéticos por STZ, tratados con insulina y/o un agonista específico de LXR-a, T091317 (T09), así como sobre animales no diabéticos tratados con Fen, T09 o una combinación de ambos. Los resultados sirvieron para evaluar tanto los efectos individuales como la interacción entre las distintas vías de activación puestas en funcionamiento en forma conjunta sobre el metabolismo de las desaturasas y sobre la composición de ácidos grasos de las membranas.

Evaluación de la activación de las diversas vías

Primeramente, para confirmar que el Fen había logrado activar a PPAR-a se midió, como generalmente se hace y como ya se explicó anteriormente, la actividad enzimática de la acil-CoA oxidasa extramitocondrial hepática. La Fig. III. 2 muestra un aumento de 8 veces sobre la actividad enzimática de ratas control como consecuencia del tratamiento con Fen. T09, por otro lado, no logró modificar este incremento.

Fig. III. 2: Comprobación de la eficacia del Fen en la activación in vivo de PPAR-a.

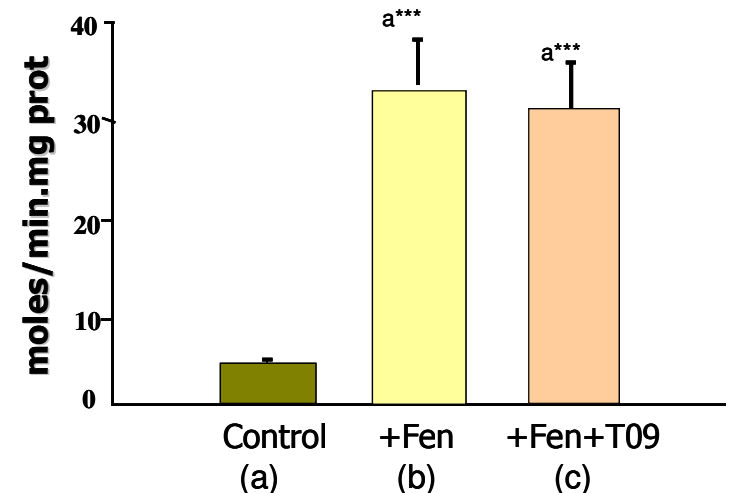

Efecto del Fen y T09 sobre la actividad de la acil-CoA oxidasa extramitocondrial en ratas no diabéticas. Los resultados se expresan en nmoles/min.mg proteína y son la media \pm S.D de 4 animales. 
Como se comentó en la introducción de este trabajo, el factor de transcripción LXR-a es capaz de activar transcripcionalmente a SREBP1 produciendo como consecuencia un aumento de la forma inmadura o citosólica de este otro factor de transcripción, la cual, a través de pasos madurativos en donde interviene entre otros la insulina, se transforma en la forma madura o nuclear denominada nSREBP-1, la cual es capaz de llevar a cabo la activación de diversos genes.

Para verificar si T09 realmente estaba produciendo efecto como activador de LXR-a, se realizó una medida del nivel del SREBP-1 hepático, tanto en sus formas citoplasmática como nuclear. T09 logró producir una activación de la vía dependiente de LXR-a, evidenciado a través de un aumento de 7,3 y 3,8 veces, de SREBP-1 tanto en su forma inactiva (citosólica) como en su forma activa (nuclear), respectivamente, (Fig. III.3) en ratas tratadas con el agonista de LXR-a comparadas con animales control sin tratar.

Fig. III.3: Comprobación del efecto T09 en la activación in vivo de SREBP-1.

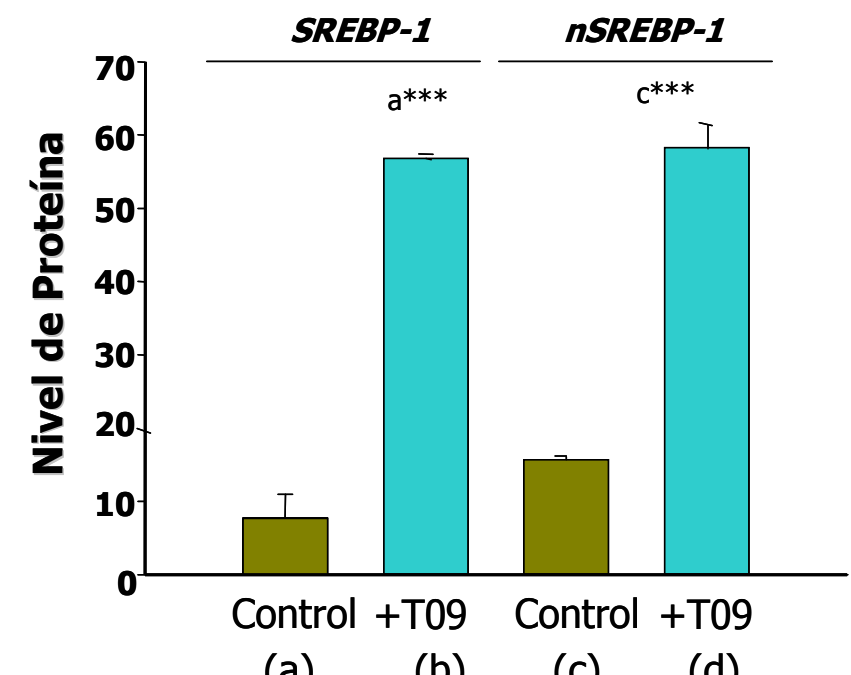
(a)
(b)
(c)
(d)

Efecto del T09 sobre la activación de las formas precursora y activa de SREBP-1. Los extractos citoplasmáticos y nucleares se obtuvieron usando NE-PER Nuclear and Cytoplasmic Extraction Reagents y se sometieron a análisis por Western blot con antiSREBP-1. Los resultados se expresan en unidades arbitrarias y son la media \pm S.D de 4 animales. Analizados por ANOVA. ${ }^{* * *} \mathrm{P}<0,001$. 


\section{Parámetros plasmáticos}

Con respecto a los parámetros plasmáticos, la administración individual de T09 no produjo ninguna modificación sobre la glucemia, insulinemia o colesterolemia.

Como ya se había visto anteriormente en este trabajo de tesis, el Fen produjo un aumento de la insulinemia (de 1,32 \pm 0,61 a 2,36 $\pm 0,13$ $\mathrm{ng} / \mathrm{mL}, \mathrm{p}<0,05)$, en los animales control sanos, atribuido al efecto estimulador de PPAR-a sobre la secreción de insulina, sin alterar ni la glucemia ni la colesterolemia. Cuando se combinó la administración de ambos fármacos, el T09 no produjo ningún cambio adicional sobre el efecto que Fen había producido sobre la glucemia o insulinemia.

La combinación de ambos fármacos, T09 y Fen, fue exitosa

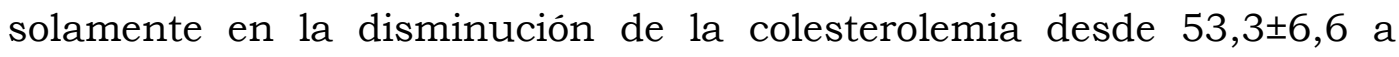
$25,7 \pm 5,7 \mathrm{mg} / 100 \mathrm{ml}(\mathrm{p}<0,001)$

Finalmente, la administración de insulina fue capaz de normalizar la glucemia en los animales diabéticos tratados en comparación con los diabéticos sin tratamiento hormonal, parámetro que por las razones ya explicadas anteriormente (ver III.A), se midió 4 horas después de inyectar insulina.

\section{Efecto sobre el nivel de ARNm de desaturasas}

Con respecto a lo que sucede con el ARNm de las desaturasas, se encontró que los tres fármacos usados, insulina, Fen y T09, produjeron en general un patrón de aumento de la expresión de las tres enzimas estudiadas (Fig. III. 4).

La administración de T09 incrementó el ARNm de las tres enzimas medidas, tanto en animales diabéticos como no diabéticos, comprobándose la insulino-independencia de esta vía sobre la 
activación de los genes, así como un sinergismo durante la administración combinada de insulina y T09.

Se conoce además que en animales diabéticos el factor SREBP-1c está inactivado debido a que en su maduración hidrolitica requiere de la participación de la insulina, por lo que el efecto de LXR-a sobre las desaturasas estaría ocurriendo en forma SREBP-1c-independiente. Cuando la insulina está presente, esta provocaría la conversión del SREBP-1a citosólico a nSREBP-1c, produciendo el sinergismo entre ambas vías.

Fig. III.4: Efectos de T09 y fenofibrato (Fen) en ratas control (C) y diabéticas (D) tratadas con T09 (T09) e insulina (Ins) sobre el ARNm de SCD1, y $\Delta 5$ y $\Delta 6$ desaturasas.

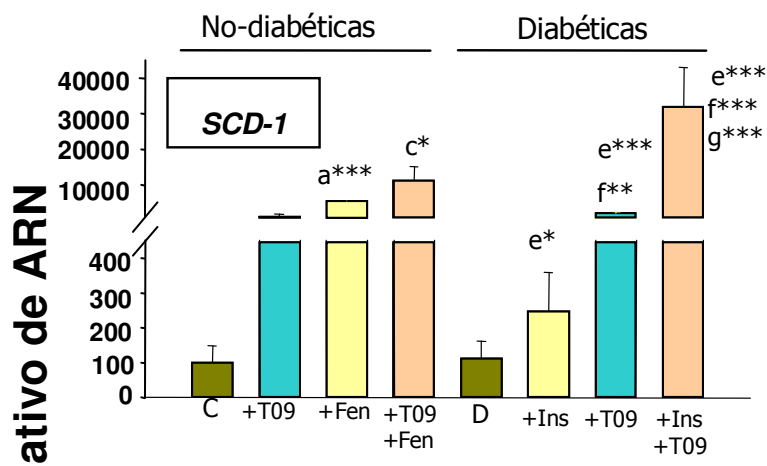

(a) (b) (c) (d) (e) (f) (g) (h)

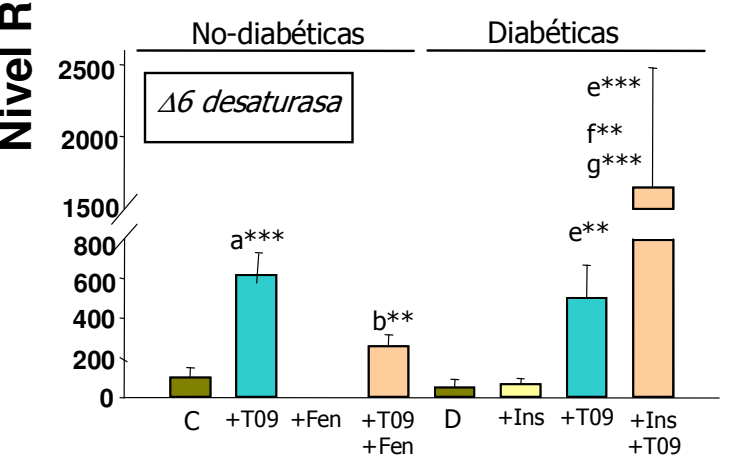

(a) (b) (c) (d) (e) (f) (g) (h)

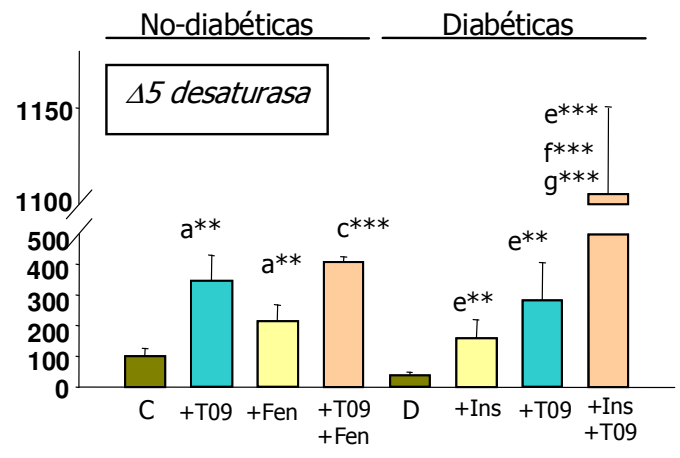

(a) (b) (c) (d) (e) (f) (g) (h)

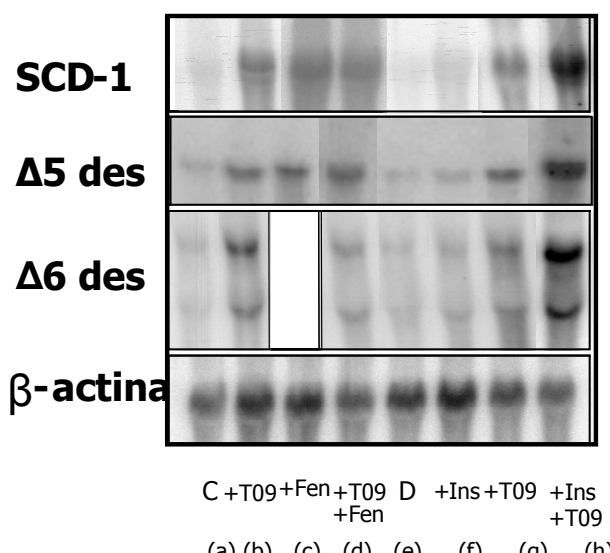

$\begin{array}{lllll}\text { (a) (b) (c) (d) (e) (f) (g) (h) } & \end{array}$

El análisis por Northern se realizó como se describió en Metodología. Los resultados se expresan en unidades arbitrarias referidas a las ratas control (100) como la media \pm SD de 4 animales. Resultados analizados por ANOVA. Las diferentes letras superindices indican diferencias entre este valor y el del grupo encabezado por dicha letra ${ }^{* * *} \mathrm{P}<0,001 ;{ }^{* *} \mathrm{P}<0,01$; ND no determinado. 
En animales no diabéticos, el Fen produjo una activación de la expresión de $\Delta 5$ desaturasa y SCD1. Ya se había evaluado previamente (ver III.A) el efecto del Fen sobre el metabolismo de las desaturasas hepáticas en animales control sanos y en animales diabéticos, y su interacción con la insulina, en donde se demostró la independencia entre las vías dependientes de PPAR-a y de insulina, y la aditividad de efectos para el tratamiento combinado.

Lo último para analizar es la interacción entre los tratamientos con Fen y T09. Cuando se analiza el nivel del ARNm de las desaturasas (solamente para SCD1 y $\Delta 5$ desaturasa, debido a que por problemas técnicos no pudo determinarse el nivel de ARNm de $\Delta 6$ para los animales no diabéticos tratados con Fen) se observa que, si bien ambos agonistas, Fen y T09, logran activar la expresión de las mismas, el tratamiento combinado no presenta una adición entre los efectos activadores individuales del Fen y T09. Dado que tanto PPAR-a como LXR-a necesitan una heterodimerización previa con RXR para poder actuar sobre sus genes blanco, probablemente este efecto sea una consecuencia de la competencia entre ambas vias por este otro factor de transcripción lo que impide que la activación final supere cierto límite.

Efecto sobre la actividad enzimática de las desaturasas hepáticas.

En el caso de las actividades enzimáticas desaturantes, se encontró un patrón de comportamiento similar al de los ARNm (Fig. III.5). O sea, se encontró una activación de las actividades enzimáticas de las desaturasas hepáticas dada por insulina y por T09, en forma independiente a la presencia de la hormona. La única diferencia fue que el fuerte efecto cooperativo que se reflejó en el nivel de los ARNm frente a la administración de ambos fármacos no se evidenció a nivel de las 
actividades enzimáticas. Debido al gran número de antecedentes al respecto, no se realizó la medida de actividad desaturante en el lote diabético tratado con insulina.

También se observó el efecto activador del Fen sobre la actividad de las tres enzimas estudiadas, fenómeno ya demostrado anteriormente en este trabajo (ver III.A), el cual se probó como insulin-independiente.

Fig. III.5: Actividades enzimáticas de $\Delta 9, \Delta 6$ y $\Delta 5$ desaturasas en animales diabéticos (D) y controles (C) no diabéticos tratados con fenofibrato (Fen) T091317 (T09) e insulina (Ins).
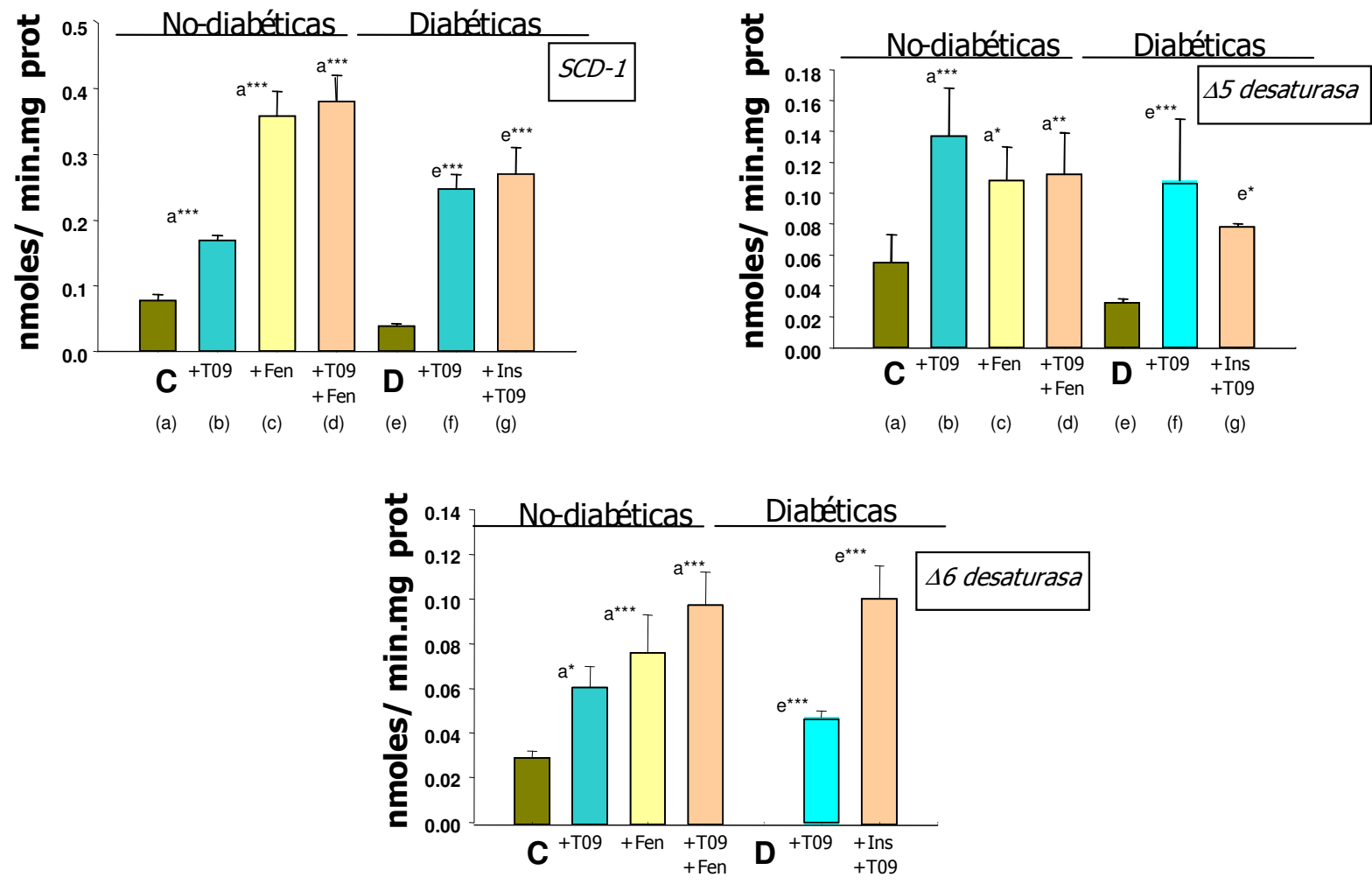

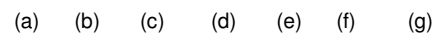

Las actividades se expresan en nmoles/min. mg proteína y son la media \pm S.D de 4 animales. Las diferencias estadísticas se analizaron con ANOVA. ${ }^{* * *} \mathrm{P}<0,001,{ }^{* *} \mathrm{P}<$ $0,01,{ }^{*} \mathrm{P}<0,05$.

Por último, se evaluaron los efectos de los tratamientos individuales y combinado, entre T09 y Fen, sobre los niveles de actividad $\Delta 9, \Delta 6$ y $\Delta 5$ desaturante. La competencia establecida entre la activación de los ARNm de dichas enzimas se reflejó también en las 
medidas de las actividades enzimáticas (Fig.III 5), en donde no se encontró una adición de los efectos cuando se midieron las actividades desaturantes del lote con tratamiento combinado, en comparación con los lotes que recibieron las drogas en forma individual.

Debido a problemas técnicos que se presentaron en la medida del ARNm correspondiente a $\Delta 6$ desaturasa hepática en el lote tratado con Fen, se evaluó el efecto del tratamiento con T09 y/o Fen sobre el contenido microsomal de $\Delta 6$ desaturasa mediante Western blot, usando anticuerpos producidos en nuestro laboratorio.

La Fig.III.6 muestra el efecto activador dado por ambas vías sobre el nivel de $\Delta 6$ desaturasa microsomal hepática cuando se evaluó la administración separada de los fármacos. Al igual que en el caso de los ARNm y de las actividades enzimáticas evaluadas anteriormente, se estableció también una efecto a través del cual no se permitió que el nivel de $\Delta 6$ desaturasa microsomal hepática aumente en forma aditiva debido al efecto combinado entre ambos agonistas.

Fig. III.6: Análisis por Western blot de $\Delta 6$ desaturasa microsomal hepática de ratas control no diabéticas (C) tratadas con T09 (T09) y fenofibrato (Fen).

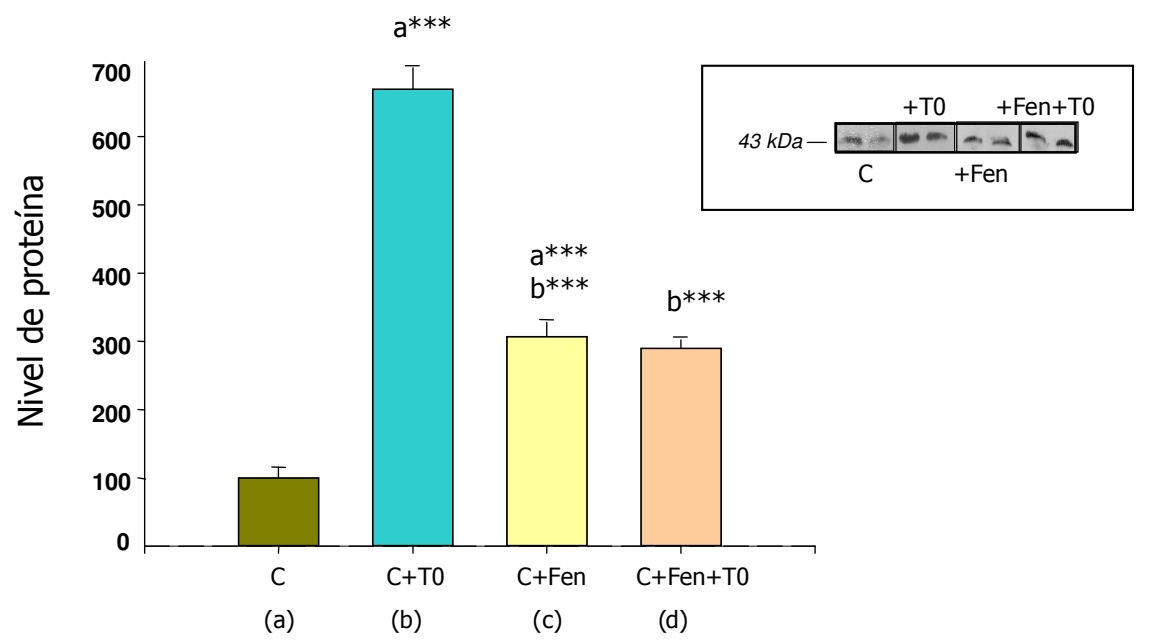

Se separaron $70 \mu \mathrm{g}$ de proteína microsomal/calle mediante SDS-PAGE, y se analizaron con anti- $\Delta 6$ y anti-IgG de conejo. Los resultados se expresan como unidades arbitrarias referidas a las ratas no diabéticas (100) y son la media \pm SD de 3 animales. Las diferencias estadisticas se analizaron por ANOVA. ${ }^{* * *} \mathrm{P}<0,001$. 
Efecto de sobre la actividad de palmitoil-CoA elongasa hepática

Para tener una visión de lo que ocurre, como consecuencia de estos tratamiento, sobre un sistema enzimático elongante que en los últimos años ha estado cobrando cada vez más importancia en lo que respecta a la regulación de los niveles finales de ácidos grasos celulares, se midió el efecto de los fármacos usados anteriormente, insulina, Fen y T09, sobre la actividad de la enzima palmitoil-CoA elongasa hepática.

Se observa en la Fig.III.7 que la activación de las vías antes mencionadas produce un incremento de la actividad de esta enzima con un patrón de comportamiento similar al encontrado para el nivel de ARNm de las desaturasas, demostrándose un sinergismo entre las vías dependientes de insulina y LXRa. A diferencia de las desaturasas, en este caso aparece un efecto de adición entre los efectos activadores dados T09 y Fen. Por lo tanto, a partir de estos resultados se puede ver que para tratar de predecir los niveles finales se ácidos grasos en las membranas no se debe pasar por alto el efecto producido a través de la regulación de las elongasas.

Además, y como se discutirá más adelante con respecto a las composiciones de ácidos grasos, estas medidas contribuyen a aclarar alguna duda planteada en III.A en lo que respecta al efecto del Fen sobre la actividad de palmitoil-CoA elongasa hepática. 
Fig. III.7: Efecto de T09 (T09), fenofibrato (Fen) e insulina (Ins) sobre la actividad de palmitoil-CoA elongasa hepática de ratas no diabéticas (C) y diabéticas (D).

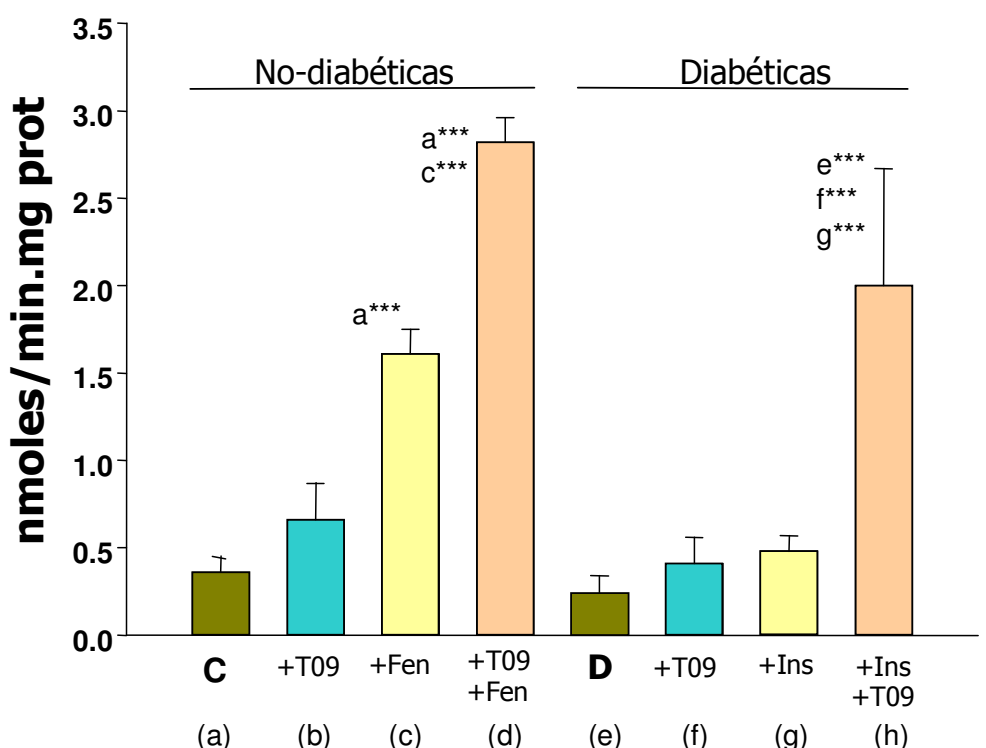

Los resultados se expresan en nmoles/min.mg. de proteína y son la media \pm S.D. de 4 animales. Las abreviaturas son como se describió anteriormente, y el análisis estadístico de las diferencias se hizo mediante ANOVA. ${ }^{* * *} \mathrm{P}<0,001$.

Efecto de los diferentes tratamientos sobre las composiciones lipidicas microsomales hepáticas

La Tabla III.8 muestra que los agentes antes mencionados, cuando actúan durante un periodo tan corto como 9 días, producen cambios muy poco importantes en las composiciones de ácidos grasos de microsomas hepáticos.

La diabetes no provocó alteraciones significativas sobre la composición de ácidos grasos de membrana microsomal de los animales control, solamente se detectó un aumento de 22:6n-3, tema que se analizará más profundamente en la discusión. También se observó un incremento de 22:4n-6 como consecuencia de la diabetes, lo cual, al igual que en el caso del 22:6n-3, no se correlaciona con los cambios de expresión y actividad que se midieron para las desaturasas, los cuales no se modifican o disminuyen como consecuencia de la patología. 
Se pudieron detectar algunos pequeños cambios provocados por el agonista de PPAR-a, Fen. Este fármaco no solo duplicó los porcentajes de ácidos palmitoleico y oleico en el lote tratado con Fen en comparación con el lote control sano, sino que también incrementó el ácido araquidónico, disminuyendo al mismo tiempo la proporción del biológicamente importante ácido docosahexaenoico (22:6n-3) y de los PUFAs n-3 de 20 y 22 átomos de carbono. También produjo un aumento de ácido palmítico y una disminución de ácido esteárico, estando este hallazgo en contra de lo que se pensaria a partir del aumento que se encontró en la actividad de palmitoil-CoA elongasa por efecto del tratamiento con Fen.

El agregado de T09 no alteró en forma significativa los parámetros medidos para el lote control sano, ni modificó los cambios producidos por la administración de Fen en forma individual. Por lo tanto, el Fen sería capaz de actuar en un plazo más corto sobre las composiciones de ácidos grasos de membrana.

En los animales diabéticos, se encontró un aumento de ácidos monoenoicos (16:1 y 18:1n-9) solamente cuando se los trató en forma combinada con insulina y T09, demostrando la mayor sensibilidad de $\mathrm{SCD} 1$, comparada con las otras desaturasas, a la activación bajo estas vías. 
Tabla III.8: Composición de ácidos grasos de lípidos microsomales hepáticos (porcentaje en peso)

\begin{tabular}{|c|c|c|c|c|c|c|c|c|}
\hline AG & $\begin{array}{l}C \\
\text { (a) }\end{array}$ & $\begin{array}{l}C+\text { T09 } \\
\text { (b) }\end{array}$ & $\begin{array}{l}\text { C+ Fen } \\
\text { (c) }\end{array}$ & $\begin{array}{c}\mathrm{C}+\underset{\text { Fen }}{\text { (d) }} \\
\text { T09 }\end{array}$ & $\begin{array}{l}\text { D } \\
(e)\end{array}$ & $\begin{array}{c}D+T 09 \\
(f)\end{array}$ & $\begin{array}{l}D+\text { Ins } \\
(g)\end{array}$ & $\begin{array}{c}D+\text { Ins+T09 } \\
\text { (h) }\end{array}$ \\
\hline 16:0 & $17,42 \pm 1,66$ & $20,75 \pm 4,38$ & 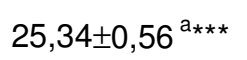 & $19,87 \pm 1,02^{c_{* * *}}$ & $17,62 \pm 0,59$ & $19,77 \pm 2,59$ & $19,59 \pm 2,82$ & $17,94 \pm 3,15$ \\
\hline $16: 1$ & $0,32 \pm 0,10$ & $0,58 \pm 0,07$ & $0,61 \pm 0,10^{a_{\star \star \star}}$ & $0,74 \pm 0,05^{a_{* * *}}$ & $0,32 \pm 0,08$ & $0,46 \pm 0,30$ & $0,17 \pm 0,13$ & $1,10_{g_{\star \star \star}}^{ \pm 0,16^{e_{* \star \star}}}$ \\
\hline 18:0 & $28,97 \pm 2,19$ & $28,77 \pm 6,65$ & $23,14 \pm 0,86^{a \star \star \star}$ & $27,78 \pm 0,71^{c_{* \star *}}$ & $29,83 \pm 1,78$ & $26,80 \pm 2,18$ & $31,48 \pm 5,86$ & $23,38 \pm 1,23$ \\
\hline 18:1n-9 & $4,40 \pm 0,07$ & $6,06 \pm 0,95$ & 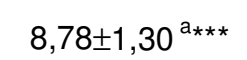 & $10,88 \pm 0,54^{a_{\star \star \star}}$ & $4,75 \pm 0,54$ & $6,02 \pm 0,92$ & $4,57 \pm 0,85$ & $12,65 \pm 2,51^{f_{* \star \star} g_{* \star \star}}$ \\
\hline 18:1n-7 & $1,15 \pm 0,09$ & $1,44 \pm 0,23$ & $0,85 \pm 0,02^{a_{\star \star \star *}}$ & $0,77 \pm 0,09^{a \star \star \star}$ & $0,90 \pm 0,07$ & $1,22 \pm 0,17$ & $0,90 \pm 0,14$ & $1,82 \pm 0,17$ \\
\hline 18:2 n-6 & $11,03 \pm 0,88$ & $9,09 \pm 2,13$ & $9,30 \pm 0,93^{a_{\star}}$ & $7,68 \pm 0,69^{c_{*} a_{\star \star}}$ & $12,21 \pm 0,96$ & $9,33 \pm 0,79$ & $11,69 \pm 2,20$ & $11,34 \pm 1,69$ \\
\hline $18: 3 n-3$ & $0,58 \pm 0,10$ & $0,49 \pm 0,18$ & $0,51 \pm 0,09$ & $0,44 \pm 0,16$ & $0,39 \pm 0,19$ & $0,46 \pm 0,16$ & $0,52 \pm 0,20$ & $0,36 \pm 0,18$ \\
\hline $20: 3 n-9$ & $0,20 \pm 0,02$ & $0,17 \pm 0,05$ & $0,29 \pm 0,08$ & $0,27 \pm 0,05$ & $0,14 \pm 0,01$ & $0,15 \pm 0,02$ & $0,17 \pm 0,09$ & $0,25 \pm 0,04$ \\
\hline $20: 3 n-6$ & $0,35 \pm 0,05$ & $0,67 \pm 0,02$ & $1,71 \pm 0,35^{a \star \star \star}$ & 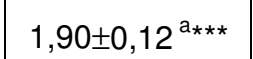 & $0,76 \pm 0,10$ & $0,57 \pm 0,03$ & $0,74 \pm 0,23$ & $1,06 \pm 0,27$ \\
\hline $20: 4 n-6$ & $28,81 \pm 2,61$ & $24,33 \pm 6,62$ & $26,21 \pm 1,84^{a_{\star}}$ & $26,53 \pm 0,69^{a_{*}}$ & $23,89 \pm 1,30$ & $23,87 \pm 2,47$ & $22,33 \pm 2,75$ & $20,85 \pm 0,84$ \\
\hline $20: 5 n-3$ & $0,51 \pm 0,04$ & $0,44 \pm 0,13$ & $0,15 \pm 0,03^{a \star \star \star}$ & $0,14 \pm 0,01^{a * \star \star}$ & $0,56 \pm 0,04$ & $0,58 \pm 0,07$ & $0,51 \pm 0,06$ & $0,76 \pm 0,15$ \\
\hline $22: 4 n-6$ & $0,47 \pm 0,10$ & $0,38 \pm 0,08$ & $0,06 \pm 0,11$ & $0,09 \pm 0,11$ & $1,02 \pm 0,38^{a_{* *}}$ & $1,46 \pm 0,64^{b_{* *}}$ & $0,80 \pm 0,21$ & $1,28 \pm 0,18$ \\
\hline $22: 5 n-3$ & $0,72 \pm 0,08$ & $0,68 \pm 0,17$ & $0,27 \pm 0,06^{a_{* * *}}$ & $0,21 \pm 0,04^{a * * *}$ & $0,59 \pm 0,07$ & $0,60 \pm 0,07$ & $0,58 \pm 0,07$ & $0,76 \pm 0,14$ \\
\hline $22: 6 n-3$ & $5,08 \pm 0,45$ & $6,17 \pm 1,13$ & $2,80 \pm 0,63^{a^{* \star *}}$ & $2,71 \pm 0,24^{a * * *}$ & $7,03 \pm 0,88^{a *}$ & $8,72 \pm 1,52^{b *}$ & $5,98 \pm \underset{f_{*}}{ \pm} 1,09$ & $6,47 \pm 0,81$ \\
\hline \begin{tabular}{|l} 
AG totales \\
Mg AG/mg prot.
\end{tabular} & $0,27 \pm 0,05$ & $0,30 \pm 0,02$ & $0,32 \pm 0,03$ & $0,30 \pm 0,02$ & $0,33 \pm 0,04$ & $0,39 \pm 0,07$ & $0,29 \pm 0,02$ & $0,29 \pm 0,03$ \\
\hline
\end{tabular}

Abreviaturas como en Fig. 2. Los resultados son la media \pm SD de 4 animales. Las diferencias estadisticas se analizaron mediante ANOVA. *** $\mathrm{P}<0,001,{ }^{* *} \mathrm{P}<0,01,{ }^{*} \mathrm{P}<0,05$. 


\section{III.C Ratas SAC (Modelo de Diabetes Mellitus Tipo II Inducida por Dieta).}

A partir de esta parte del trabajo, se estudió el efecto provocado en otros modelos de diabetes, ahora de tipo II, tratando de encontrar patrones en común entre estos modelos de diabetes de tipo insulinoresistente, en comparación con los efectos producidos por la diabetes de tipo I.

En primer lugar se utilizó un modelo de diabetes tipo II generado mediante la administración de dieta rica en sacarosa, el cual sirvió para estudiar las alteraciones producidas por la diabetes de tipo II sobre el metabolismo de las desaturasas hepáticas y la composición de ácidos grasos de membrana de diferentes fracciones.

Para esto, se alimentó a ratas Wistar durante 6 meses con dieta semisintética suplementada con $63 \%$ p/p de sacarosa (ver Metodología), mientras que otro lote de animales recibió la misma dieta pero suplementada con almidón en lugar de sacarosa para proporcionar la misma energía total a ambos grupos de animales $(-15,28 \mathrm{~kJ} / \mathrm{g}$ de comida). En todo momento, los animales pudieron beber agua ad libitum, teniendo ciclos de luz/oscuridad de 12 hs.

Repercusiones sobre los parámetros plasmáticos

Como ya ha sido reportado por otros (Soria, A y col., 2001) los significativos cambios producidos por la administración de una dieta rica en sacarosa evolucionan a medida que aumenta la duración de la alimentación con dicha dieta, llegando al denominado Período de Recurrencia alrededor de los 6 meses de administración.

De esta forma, las muestras de sangre de estos animales mostraron incrementos de los AG libres y de los TG plasmáticos, acompañados por un aumento de glucemia, en comparación con 
animales alimentados con dieta control, sin variaciones de los niveles de insulinemia (Tabla III.9).

Tabla III.9: Parámetros plasmáticos en ratas alimentadas con dieta rica en sacarosa o control durante 6 meses

\begin{tabular}{|c|c|c|}
\hline & Control & SAC \\
\hline AGL (pequiv/L) & $526,0 \pm 19,6$ & $930,0 \pm 29,4^{* * *}$ \\
\hline TG (mM) & $0,54 \pm 0,05$ & $1,20 \pm 0,09^{* * *}$ \\
\hline Glucosa (mM) & $6,10 \pm 0,19$ & $6,98 \pm 0,16^{* *}$ \\
\hline Insulina (pU/m) & $8,36 \pm 1,48$ & $7,45 \pm 1,34$ \\
\hline
\end{tabular}

Los valores son la media $\pm \mathrm{SEM}, \mathrm{n}=5$. Los asteriscos indican valores que son diferentes del control ${ }^{* * *} \mathrm{P}<0,001 ;{ }^{* *} \mathrm{P}<0,01$ evaluados mediante Student's t-test.

Efecto sobre expresión y actividad de las desaturasas

Luego de 6 meses de tratamiento con dieta rica en sacarosa, dentro del Periodo de Recurrencia, los parámetros correspondientes a las desaturasas hepáticas mostraron un incremento de aproximadamente $50 \%$ en la expresión de SCD1 (Fig. III.8), acompañado por una duplicación de la actividad enzimática de $\Delta 9$ desaturasa (Tabla III.10), a pesar de la similitud en los niveles de insulinemia medidos tanto para las ratas alimentadas con sacarosa como con almidón.

Con respecto a las restantes enzimas desaturantes hepáticas, en la Tabla III.10 se observa que las actividades de $\Delta 5$ y $\Delta 6$ desaturasa, luego de 6 meses de tratamiento con dieta rica en sacarosa, se incrementaron en forma significativa con respecto a los controles suplementados con almidón.

El incremento en el nivel de la actividad $\Delta 6$ desaturante se correlacionó con la medida del nivel de ARNm para esta enzima (Fig.III. 8), el cual prácticamente se duplicó al cabo de 6 meses de dieta con sacarosa. 
Fig. III.8: Efecto de la dieta rica en sacarosa sobre el nivel del ARNm de SCD1 y $\Delta 6$ desaturasa hepáticas.

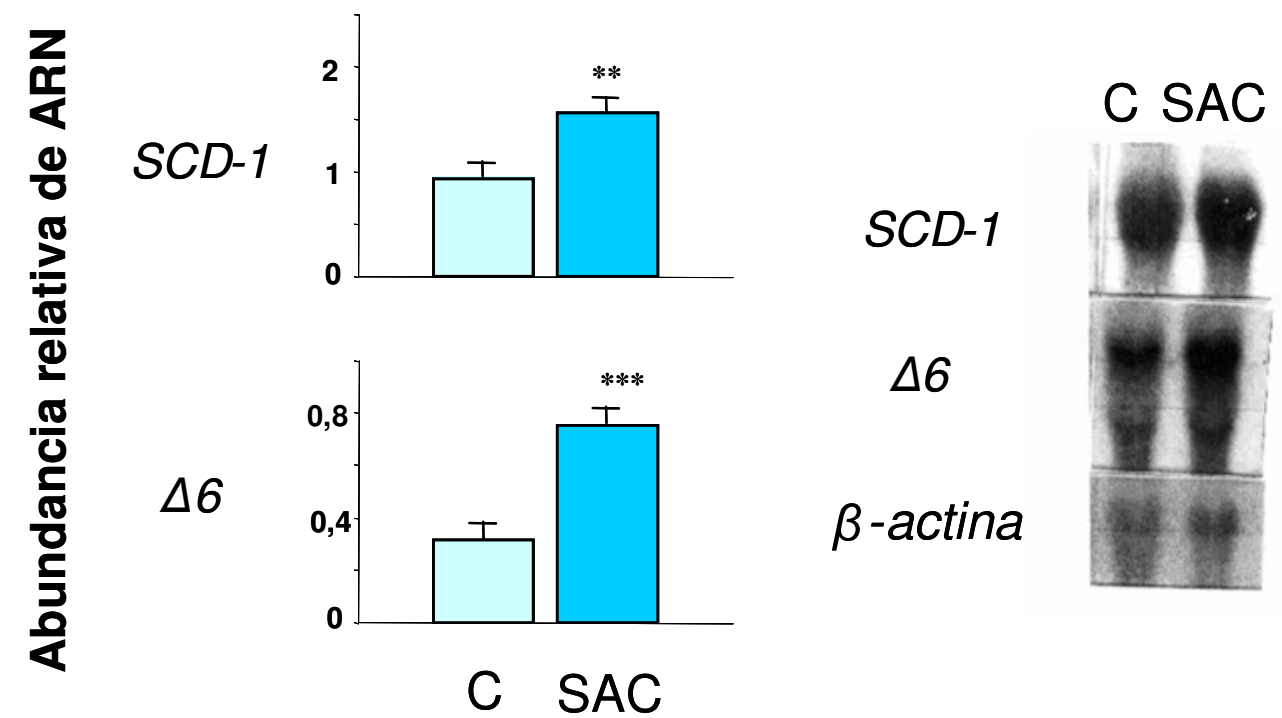

Las señales se cuantificaron mediante ID Image System Software a partir de los Northern blots. Los resultados son la media $\pm \mathrm{SD}, \mathrm{n}=3$. Los asteriscos indican valores que difieren del control, ${ }^{* * *} \mathrm{P}<0,001 ;{ }^{* *} \mathrm{P}<0,05 ; \mathrm{NS}$, no significativo evaluado mediante Student's t-test.

Tabla III.10: Actividades $\Delta 9, \Delta 6$, y $\Delta 5$ desaturantes de microsomas hepáticos a los 6 meses con dieta rica en sacarosa

\begin{tabular}{|c|c|c|}
\hline Desaturasa & Control & SAC \\
\hline $\mathbf{\Delta 9}$ & $0,141 \pm 0,039$ & $0,391 \pm 0,070^{* * * *}$ \\
\hline $\mathbf{\Delta 6}$ & $0,150 \pm 0,029$ & $0,276 \pm 0,056^{* * *}$ \\
\hline $\mathbf{\Delta 5}$ & $0,137 \pm 0,018$ & $0,213 \pm 0,033^{* *}$ \\
\hline
\end{tabular}

Los resultados son la media $\pm \mathrm{SD}, \mathrm{n}=5$. Las diferencias se evaluaron usando ANOVA. Las diferentes letras superindices indican diferencias entre este valor y el del grupo encabezado por esa letra. ${ }^{* * *} \mathrm{P}<0,001 \mathrm{y}{ }^{* *} \mathrm{P}<0,01$.

Efectos sobre parámetros lipidicos

En las Tablas III.11, III.12 y III.13 se pueden observar los efectos de la dieta rica en sacarosa durante 6 meses sobre las composiciones de ácidos grasos (AG) de hígado, de microsomas hepáticos y de fosfolípidos y TG de microsomas hepáticos, respectivamente.

En general, en todas las fracciones lipídicas analizadas, las composiciones de ácidos grasos no tuvieron variaciones significativas con respecto a los ácidos grasos que dependen directamente de SCD1, o sea tanto en los saturados 16:0 y 18:0, como en los monoenoicos 16:1 y 
18:1n-9. Sin embargo, los cocientes 16:1/16:0 y 18:1/18:0 tuvieron un pequeño aumento en los animales diabéticos con respecto a los controles, para todos las composiciones analizadas, coincidiendo de esta forma con el aumento medido para el nivel de ARNm y actividad de SCD1 hepática.

Tabla III.11: Composición de ácidos grasos de hígado total

\begin{tabular}{|l|c|c|}
\hline \multicolumn{1}{|c|}{ AG } & Control & SAC \\
\hline $\mathbf{1 6 : 0}$ & $22,32 \pm 1,14$ & $21,04 \pm 0,67$ \\
\hline $\mathbf{1 6 : 1}$ & $1,89 \pm 0,30$ & $1,69 \pm 0,19$ \\
\hline $\mathbf{1 8 : 0}$ & $14,10 \pm 1,39$ & $15,44 \pm 0,41$ \\
\hline $\mathbf{1 8 : 1} \mathbf{n - 9}$ & $10,74 \pm 2,07$ & $12,03 \pm 0,55$ \\
\hline $\mathbf{1 8 : 2}$ n-6 & $22,65 \pm 1,35$ & $16,68 \pm 0,94^{* * *}$ \\
\hline $\mathbf{2 0 : 4}$ n-6 & $18,29 \pm 1,41$ & $20,52 \pm 1,00$ \\
\hline $\mathbf{2 2 : 4}$ n-6 & $0,65 \pm 0,08$ & $1,10 \pm 0,19^{*}$ \\
\hline $\mathbf{2 2 : 5} \mathbf{n - 6}$ & $0,94 \pm 0,17$ & $3,26 \pm 0,72^{* * * *}$ \\
\hline $\mathbf{2 2 : 6} \mathbf{n - 3}$ & $4,10 \pm 0,64$ & $2,96 \pm 0,44$ \\
\hline $\mathbf{1 6 : 1 / 1 6 : 0}$ & 0,085 & 0,093 \\
\hline $\mathbf{1 8 : 1 / 1 8 : 0}$ & 0,76 & 0,78 \\
\hline $\mathbf{2 0 : 4 / 1 8 : 2}$ & 0,81 & 1,23 \\
\hline
\end{tabular}

Los resultados son la media $\pm \mathrm{SD}, \mathrm{n}=4$. Las diferencias se analizaron usando ANOVA. ${ }^{* * *} \mathrm{P}<0,001,{ }^{* *} \mathrm{P}<0,01,{ }^{*} \mathrm{P}<0,05$. Solamente se tuvieron en cuenta los AG más importantes. Con los demás AG se llega al 100\%.

En el análisis del comportamiento de los ácidos grasos poliinsaturados, cuyas variaciones pueden reflejar los cambios en la expresión y actividad de $\Delta 6$ y $\Delta 5$ desaturasas hepáticas, se observó en general un aumento del cociente 20:4/18:2 y de los PUFAs de la serie n-6, 22:4n-6, y 22:5n-6 en los lípidos totales hepáticos (Tablas III.11) en correlación con el aumento de actividad desaturante $\Delta 5$ y $\Delta 6$ luego de 6 meses de tratamiento.

En los microsomas de hígado (Tabla III.12) y en los fosfolipidos de microsomas hepáticos (Tabla III.13) se observaron resultados similares con aumentos de los PUFAs de la serie n-6 y del cociente 20:4/18:2, lo que también estuvo de acuerdo con el aumento de las $\Delta 5$ y $\Delta 6$ desaturasas hepáticas. 
Tabla III.12: Composición de ácidos grasos de microsomas hepáticos

\begin{tabular}{|l|c|c|}
\hline & \multicolumn{2}{|c|}{$\mathbf{( g / 1 0 0 g})$} \\
\hline \multicolumn{1}{|c|}{ AG } & Control & SAC \\
\hline $\mathbf{1 6 : 0}$ & $21,37 \pm 1,21$ & $20,83 \pm 2,04$ \\
\hline $\mathbf{1 8 : 0}$ & $0,80 \pm 0,55$ & $0,98 \pm 0,22$ \\
\hline $\mathbf{1 8 : 1} \mathbf{~ n - 9}$ & $18,18 \pm 0,82$ & $19,18 \pm 1,77$ \\
\hline $\mathbf{1 8 : 2}$ n-6 & $6,20 \pm 1,46$ & $7,13 \pm 0,23$ \\
\hline $\mathbf{2 0 : 4}$ n-6 & $14,57 \pm 1,64$ & $11,41 \pm 0,93^{* *}$ \\
\hline $\mathbf{2 2 : 4}$ n-6 & $26,83 \pm 1,97$ & $27,49 \pm 2,65$ \\
\hline $\mathbf{2 2 : 5}$ n-6 & $0,59 \pm 0,09$ & $1,10 \pm 0,22^{*}$ \\
\hline $\mathbf{2 2 : 6}$ n-3 & $0,79 \pm 0,16$ & $3,71 \pm 0,98^{* * *}$ \\
\hline $\mathbf{1 6 : 1 / 1 6 : 0}$ & $6,21 \pm 0,97$ & $3,38 \pm 0,32^{* * *}$ \\
\hline $\mathbf{1 8 : 1 / 1 8 : 0}$ & 0,037 & 0,047 \\
\hline $\mathbf{2 0 : 4 / 1 8 : 2}$ & 0,34 & 0,37 \\
\hline
\end{tabular}

Tabla III.13: Composición de ácidos grasos de fosfolipidos y TG microsomales hepáticos

\begin{tabular}{|l|c|c|}
\hline \multicolumn{1}{|c|}{ AG } & \multicolumn{2}{|c|}{ Fosfolípidos (g/100g) } \\
\hline $\mathbf{1 6 : 0}$ & Control & SAC \\
\hline $\mathbf{1 6 : 1}$ & $22,32 \pm 1,14$ & $21,04 \pm 0,67$ \\
\hline $\mathbf{1 8 : 0}$ & $0,64 \pm 0,05$ & $0,66 \pm 0,15$ \\
\hline $\mathbf{1 8 : 1}$ n-9 & $21,67 \pm 1,39$ & $20,79 \pm 0,40$ \\
\hline $\mathbf{1 8 : 2}$ n-6 & $3,24 \pm 0,16$ & $4,42 \pm 0,27^{* * *}$ \\
\hline $\mathbf{2 0 : 4}$ n-6 & $11,33 \pm 0,64$ & $9,25 \pm 0,80^{*}$ \\
\hline $\mathbf{2 2 : 4}$ n-6 & $20,14 \pm 1,19$ & $30,79 \pm 0,59^{* * *}$ \\
\hline $\mathbf{2 2 : 5}$ n-6 & $0,50 \pm 0,06$ & $1,13 \pm 0,08^{* * *}$ \\
\hline $\mathbf{2 2 : 6}$ n-3 & $0,83 \pm 0,28$ & $4,11 \pm 1,37^{* *}$ \\
\hline $\mathbf{1 6 : 1 / 1 6 : 0}$ & $6,16 \pm 0,92$ & $3,44 \pm 0,55^{* *}$ \\
\hline $\mathbf{1 8 : 1 / 1 8 : 0}$ & 0,029 & 0,031 \\
\hline $\mathbf{2 0 : 4 / 1 8 : 2}$ & 0,15 & 0,21 \\
\hline & 2,57 & 3,33 \\
\hline $\mathbf{1 6 : 0}$ & & TG (g/100g) \\
\hline $\mathbf{1 6 : 1}$ & $23,88 \pm 1,56$ & $25,42 \pm 0,61$ \\
\hline $\mathbf{1 8 : 0}$ & $2,75 \pm 0,32$ & $2,96 \pm 0,22$ \\
\hline $\mathbf{1 8 : 1}$ n-9 & $5,16 \pm 0,72$ & $5,80 \pm 0,81$ \\
\hline $\mathbf{1 8 : 2}$ n-6 & $20,18 \pm 1,73$ & $26,61 \pm 0,82$ \\
\hline $\mathbf{2 0 : 4}$ n-6 & $38,90 \pm 0,18$ & $30,41 \pm 0,58^{*}$ \\
\hline $\mathbf{2 2 : 6}$ n-3 & $6,86 \pm 0,07$ & $5,43 \pm 0,32$ \\
\hline $\mathbf{1 6 : 1 / 1 6 : 0}$ & trazas & trazas \\
\hline $\mathbf{1 8 : 1 / 1 8 : 0}$ & 0,115 & 0,116 \\
\hline $\mathbf{2 0 : 4 / 1 8 : 2}$ & 3,91 & 4,59 \\
\hline
\end{tabular}

Los resultados son la media $\pm \mathrm{SD}, \mathrm{n}=4$. Las diferencias se analizaron usando ANOVA. ${ }^{* * *} \mathrm{P}<0,001,{ }^{* *} \mathrm{P}<0,01,{ }^{*} \mathrm{P}<0,05$. Solamente se tuvieron en cuenta los AG más importantes. Con los demás AG se llega al 100\%. 
En contra del aumento encontrado en los niveles de casi todos los ácidos grasos poliinsaturados en el lote alimentado con la dieta rica en sacarosa, el DHA (22:6n-3) tuvo un comportamiento inverso, como en el caso de los animales con diabetes de tipo 1, encontrándose para este modelo de diabetes de tipo II una disminución del mismo en todas las fracciones lipidicas analizadas (Tablas III.11 a 13). 


\section{D Ratas eSS (Modelo de Diabetes Mellitus Tipo II).}

Este otro modelo animal desarrollado en Rosario sirvió para continuar con la evaluación de los efectos de la Diabetes Mellitus de Tipo II sobre el metabolismo de las enzimas desaturantes hepáticas y sobre las composiciones de ácidos grasos de membrana en hígado, tratando de encontrar alguna correlación, si existiese, con los del modelo alimentado en base a dieta rica en sacarosa (SAC), y comparando a ambos modelos con los hallazgos obtenidos en el análisis del modelo de Diabetes de tipo I.

\section{Parámetros plasmáticos}

En animales de 6 meses de edad la concentración de glucosa plasmática en ayunas fue levemente superior a los controles $(1,36 \pm$ $0,05 \mathrm{~g} / \mathrm{L}$ vs $1,19 \pm 0,08 \mathrm{~g} / \mathrm{L}, \mathrm{p}<0,05)$ coincidiendo con lo encontrado en trabajos anteriores (Martinez, SM y col., 1993). Como ya se explicó previamente, a esta edad, este tipo de animales ya desarrolló una NIDDM moderada con una prueba de tolerancia a la glucosa alterada.

Por su parte, la trigliceridemia tuvo un aumento significativo $(\mathrm{P}<$ $0,005)(0,49 \pm 0,10 \mathrm{~g} / \mathrm{L}$ vs. 2,14 $\pm 0,61 \mathrm{~g} / \mathrm{L})$ en comparación con animales sanos, típico del síndrome NIDDM.

Efecto sobre la expresión y actividad de las desaturasas hepáticas

En la Fig.III.9 se muestran los cambios en la abundancia del ARNm de SCD1, $\Delta 6$ y $\Delta 5$ desaturasa en los hígados de ratas eSS en comparación con animales control.

Se puede ver que el incremento de más del 400\% encontrado para el ARNm de SCD1, la isoforma hepática de $\Delta 9$ desaturasa, se correlaciona bien con el aumento de actividad de 6,7 veces que se muestra en la Tabla III.14 para $\Delta 9$. 
No sucedió lo mismo con la $\Delta 6$ y $\Delta 5$ desaturasas hepáticas. En este caso las actividades enzimáticas de la Tabla III.14 se muestran constantes, en concordancia con valores de ARNm sin variaciones, entre ratas eSS y control.

Fig. III.9: Nivel de ARNm de estearoil-CoA desaturasa-1 y $\Delta 6$ y $\Delta 5$ desaturasas
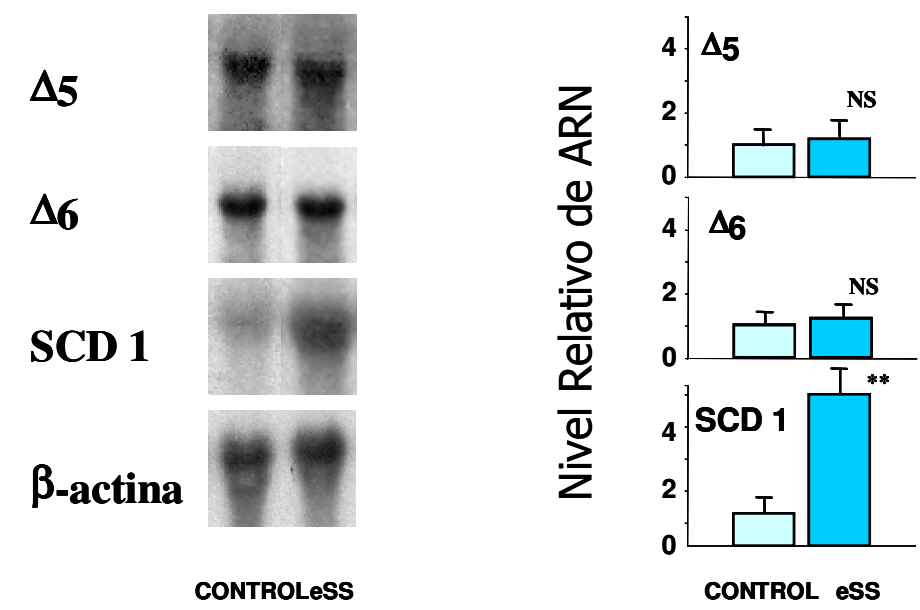

Imágenes representativas del análisis por Northern blot, realizados como se describe en Metodología Las señales se cuantificaron por medio de ID Image System Software (Kodak). Los resultados son la media $\pm \mathrm{SD}, \mathrm{n}=3$. La significancia estadística se analizó por medio de Student's t-test, con ${ }^{* *} \mathrm{P}<0,01 ;{ }^{*} \mathrm{P}<0,05$; NS no significativo.

Tabla III.14: Actividades desaturantes $\Delta 9$ y $\Delta 6$ de microsomas hepáticos de (Parte A).

\begin{tabular}{|c|c|c|}
\hline Desaturasas & Control & eSS \\
\hline$\Delta 9$ & $0,013 \pm 0,001$ & $0,100 \pm 0,015^{\star \star \star}$ \\
\hline$\Delta 6$ & $0,174 \pm 0,067$ & $0,265 \pm 0,035$ \\
\hline$\Delta 5$ & $0,147 \pm 0,039$ & $0,096 \pm 0,020$ \\
\hline
\end{tabular}

Se usaron $\left[1-{ }^{14} \mathrm{C}\right]$ ácido esteárico, $\left[1-{ }^{14} \mathrm{C}\right]$ ácido linoleico y $\left[1-{ }^{14} \mathrm{C}\right]$ ácido eicosatrienoico (n-6) como sustratos, respectivamente. Los resultados se expresan como nmoles producto/min. $\mathrm{mg}$ proteina y son la media $\pm \mathrm{SD}, \mathrm{n}=3$ y se evaluaron mediante Student's t-test. ${ }^{* * *} \mathrm{P}<0,001$.

Para contrastar si el resultado del aumento de expresión de SCD1 era correlativo con el contenido proteico total microsomal de la enzima, se realizó un análisis mediante Western blot, utilizando anticuerpos policlonales de conejo anti-SCD1 preparados en nuestro laboratorio (ver Metodologia). En la medida del contenido de SCD1 microsomal (Fig. III.10) se encontró un incremento de aproximadamente 7 veces, lo cual 
se correlaciona muy bien con el aumento medido a través de la actividad enzimática, lo que nos podria indicar que el incremento del ARNm produce un aumento en la cantidad de enzima funcional, la que además estaría totalmente activa.

Fig. III.10: Nivel de SCD1 mediante Western blot

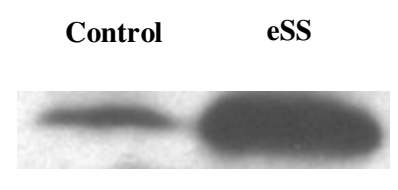

Se analizaron microsomas hepáticos sembrando $70 \mu \mathrm{g} / \mu \mathrm{l}$ de proteina total y separando por SDS-PAGE. Se transfirió a nitrocelulosa y se incubó con anti-SCD1 preparado en el laboratorio y con anti-IgG de conejo conjugado con peroxidasa. Se reveló por electroquimioluminiscencia y las señales se cuantificaron por medio de ID Image System Software (Kodak).

Efectos sobre composiciones de ácidos grasos de membrana

A partir de los resultados precedentes, era de esperar que, en los lípidos microsomales hepáticos de las ratas eSS, las proporciones de los ácidos palmitoleico (16:1) y oleico (18:1n-9) se incrementaran, así como también los cocientes 16:1/16:0 y 18:1n-9/18:0, debido al aumento del ARNm y actividad de SCD1. De esta forma, se encontró un aumento de 16:1 y $18: 1 \mathrm{n}-9$ de 1,6 y 0,6 veces, respectivamente, mientras que los cocientes mencionados aumentaron en 1,4 y 0,7 veces, respectivamente, en comparación con los controles (Tabla III.15), confirmando entonces un incremento en las vías de desaturación hacia ácidos grasos monoenoicos. Estos resultados, al igual que los niveles de ARNm y actividad de SCD1 son opuestos a los que por lo general se hallan en modelos diabéticos de tipo I, en donde las variaciones en las composiciones de ácidos grasos de membrana hepáticos acompañan al descenso de expresión y actividad de SCD1.

Por otro lado, la ausencia de una diferencia estadística para el ácido araquidónico $(20: 4 n-6)$ se correlaciona bien con la ausencia de 
cambio en la actividad de $\Delta 5$ y $\Delta 6$ desaturasas hepáticas (Tabla III.15). Sin embargo, el aumento que se encontró en el ácido graso minoritario 20:3n-6, correlacionado con una disminución del 18:2n-6, podría sugerir una pequeña activación de la $\Delta 6$ desaturasa, la cual evidentemente no llegó a ser estadística en la medida de su ARNm y actividad.

Tabla III.15: Composición de AG (g/100g) de microsomas hepáticos.

\begin{tabular}{|c|c|c|}
\hline AG & Control & ESS \\
\hline $\mathbf{1 6 : 0}$ & $17,80 \pm 0,23$ & $18,76 \pm 1,12$ \\
\hline $\mathbf{1 6 : 1}$ & $0,26 \pm 0,14$ & $0,67 \pm 0,04^{*}$ \\
\hline $\mathbf{1 8 : 0}$ & $24,95 \pm 1,12$ & $22,68 \pm 0,18$ \\
\hline $\mathbf{1 8 : 1 n - 9}$ & $4,30 \pm 0,54$ & $6,78 \pm 0,72^{* *}$ \\
\hline $\mathbf{1 8 : 1 n - 7}$ & $1,78 \pm 0,51$ & $2,39 \pm 0,07$ \\
\hline $\mathbf{1 8 : 2 n - 6}$ & $13,87 \pm 1,15$ & $10,28 \pm 0,09^{*}$ \\
\hline $\mathbf{2 0 : 3 n - 6}$ & $0,32 \pm 0,03$ & $0,61 \pm 0,01^{* *}$ \\
\hline $\mathbf{2 0 : 4 n - 6}$ & $28,75 \pm 1,04$ & $27,42 \pm 1,07$ \\
\hline $\mathbf{2 2 : 4 n - 6}$ & $0,38 \pm 0,05$ & $0,35 \pm 0,02$ \\
\hline $\mathbf{2 2 : 5 n - 6}$ & $0,14 \pm 0,04$ & $0,20 \pm 0,05$ \\
\hline $\mathbf{2 2 : 5 n - 3}$ & $0,95 \pm 0,11$ & $0,85 \pm 0,05$ \\
\hline $\mathbf{2 2 : 6 n - 3}$ & $6,50 \pm 0,41$ & $9,01 \pm 0,50^{* *}$ \\
\hline & & 0,036 \\
\hline $\mathbf{1 6 : 1 / 1 6 : 0}$ & 0,015 & 0,299 \\
\hline $\mathbf{1 8 : 1 n - 9 / 1 8 : 0}$ & 0,172 & 2,667 \\
\hline $\mathbf{2 0 : 4 n - 6 / 1 8 : 2 n - 6}$ & 2,073 & \\
\hline
\end{tabular}

Solamente se consideraron los AG principales. Los datos son la media $\pm \mathrm{SD}, \mathrm{n}=3$. ${ }^{* * *} P$ $<0,001 ;{ }^{*} P<0,01 ;{ }^{*} P<0,05$, evaluados por Student's t-test.

En la misma tabla, también se observa un incremento significativo del DHA (22:6n-3) del 38\%, lo que indica algún otro tipo de efecto diferente cuando se lo compara con los otros PUFAs de más de 20 átomos de carbono. Este punto ya se discutió en mayor detalle considerando los resultados de los animales diabéticos de tipo I.

Además de analizar las composiciones de lípidos totales microsomales hepáticos se estudiaron también los cambios en la fracción de fosfatidilcolina (PC) de los mismos debido a que este es el 
fosfolípido mayoritario en las membranas de hígado de rata (Tabla III. 16).

Primero, se puede observar que se incrementaron el ácido oleico (18:1n-9) y el cociente 18:1n-9/18:0, comparando con los controles no diabéticos.

Tabla III.16: Composición de ácidos grasos (g/100g) de lípidos microsomales hepáticos de fracción PC.

\begin{tabular}{|c|c|c|}
\hline $\mathbf{A G}$ & Control & ESS \\
\hline 16:0 & $21,57 \pm 1,17$ & $21,83 \pm 0,17$ \\
\hline $16: 1$ & $0,79 \pm 0,23$ & $1,26 \pm 0,09^{* *}$ \\
\hline 18:0 & $27,26 \pm 0,63$ & $25,73 \pm 0,35^{\star \star}$ \\
\hline $18: 1 n-9$ & $3,83 \pm 0,19$ & $5,08 \pm 0,36^{* * *}$ \\
\hline $18: 1 n-7$ & $1,68 \pm 0,01$ & $2,24 \pm 0,17^{\star \star \star}$ \\
\hline $18: 2 n-6$ & $13,82 \pm 1,10$ & $13,71 \pm 1,24$ \\
\hline $20: 3 n-6$ & $0,63 \pm 0,08$ & $0,90 \pm 0,16^{*}$ \\
\hline $20: 4 n-6$ & $25,58 \pm 1,98$ & $25,51 \pm 1,39$ \\
\hline $22: 4 n-6$ & $0,20 \pm 0,14$ & $0,11 \pm 0,13$ \\
\hline 22:5n-6 & $0,01 \pm 0,03$ & $0,09 \pm 0,02^{* *}$ \\
\hline $22: 5 n-3$ & $0,46 \pm 0,09$ & $0,41 \pm 0,07$ \\
\hline $22: 6 n-3$ & $4,16 \pm 0,55$ & $3,13 \pm 0,52^{*}$ \\
\hline $16: 1 / 16: 0$ & 0,036 & 0,058 \\
\hline $18: 1 n-9 / 18: 0$ & 0,140 & 0,197 \\
\hline $20: 4 n-6 / 18: 2 n-6$ & 1,851 & 1,861 \\
\hline
\end{tabular}

Solamente se consideraron los AG principales. Los datos son la media $\pm \mathrm{SD}, \mathrm{n}=4$. ${ }^{* * *} P<0,001 ;{ }^{* *} P<0,01 ;{ }^{*} P<0,05$ evaluados por Student's t-test.

El ácido palmitoleico (16:1n-7) también se encontró incrementado en la fracción PC (Tabla III.16), mientras que a su vez aumentó el cociente 16:1/16:0. Más aún, en la fracción PC también se encontró un aumento estadístico de 18:1n-7, producto de elongación del 16:1n-7, estando todo de acuerdo con el aumento de la actividad $\Delta 9$ desaturante y del ARNm de SCD1 hepática.

La falta de cambio en el ácido araquidónico (20:4n-6) y en el cociente 20:4n-6/18:2n-6 estuvo de acuerdo con las invarianzas 
obtenidas para las actividades y el ARNm de $\Delta 5$ y $\Delta 6$ desaturasas hepáticas. 


\section{IV - DISCUSIÓN Y CONCLUSIONES}

\section{IV.A Interacción entre Tratamientos con Insulina y Fenofibrato Sobre Animales Diabéticos de Tipo I}

Para desentrañar la organización de la complicada red de reguladores que rigen la expresión de las enzimas desaturantes de ácidos grasos, se diseñó esta parte del trabajo con el fin de estudiar la interacción entre las vías de regulación dependientes de insulina y de PPAR-a, cuya contribución coordinada sobre dicho metabolismo es aún poco clara.

Activación de la vía dependiente de PPAR-a. La medida de la actividad de Acil-CoA oxidasa peroxisomal se eligió como el parámetro de medida de la activación de PPAR-a, ya que la misma, además de ser la enzima limitante de la beta-oxidación peroxisomal, es un blanco directo de la acción de este factor de trascripción (Dreyer, C y col., 1992; Tugwood, JD y col., 1992).

A pesar de que se sabe que la insulina tiene un poder inhibitorio sobre esta enzima en hepatocitos (Hamel, FG y col., 2001), en la Tabla III.3 se puede ver que si bien esta interacción existe, el aumento de actividad como consecuencia de la carencia de insulina es solo de 4 a 9 nmoles/min.mg prot. para los animales diabéticos, mientras que el aumento provocado por la acción del Fen es de 7 u 8 veces. Por lo tanto, 
estos resultados demuestran que el fármaco utilizado bajo las condiciones de este experimento, logró activar la vía de interés dependiente de PPAR-a.

Parámetros plasmáticos. Las Tablas III.1 y 2 demuestran que el efecto de la insulina Glargina sobre el control de la glucemia fue evidente cuando se investigó 4 horas luego de la última inyección de hormona. A las 24 horas, el lote $d+i$ presentó un nivel de insulinemia igual al grupo diabético sin tratar, y además, la hiperglucemia que había sido controlada por la hormona según la medida hecha a las 4 horas, volvió a ponerse de manifiesto 24 horas después de la última inyección de insulina.

Se conoce que esta variante de insulina posee efectos en ratas y ratones (Stammberger, I y col., 2002). Además, debido a investigaciones hechas en nuestro Instituto (Rimoldi, J y col., datos no publicados), se conoce que la $\Delta 6$ desaturasa de rata posee una activación inicial de su actividad enzimática que ocurre aproximadamente 2 horas luego de una inyección de insulina, y que el ARNm de la misma registra un aumento en su nivel aproximadamente a las 6-8 horas de la misma inyección.

Por lo tanto, teniendo en cuenta todos estos datos y las variaciones que se verán a continuación, podemos concluir que la administración de insulina Glargina fue capaz de producir un efecto medible en el lote tratado con la hormona, a pesar de que esta variación no tuvo la duración esperada de 24 horas.

La administración de Fen no tuvo efectos sobre la insulinemia en los lotes $\mathrm{d}$ y $\mathrm{d}+\mathrm{i}$, pero los animales nd mostraron un aumento del nivel de hormona circulante (Tabla III.1). A partir de esto se puede deducir que la activación de PPAR-a es capaz de estimular a las células $\beta$ pancreáticas para provocar un incremento en la secreción hormonal, 
hecho que solo puede manifestarse en los animales no diabéticos, aunque de cualquier modo esta insulinemia aumentada no fue capaz de disminuir la glucemia de los animales no diabéticos tratados con Fen en comparación con los nd sin tratar. Sugden y Holmes (Sudgen, MC y Holmes, MJ, 2004) también demostraron el potencial que posee PPAR- $\alpha$ para modular la secreción de insulina estimulada por glucosa. Además, se ha demostrado que ratones knock-out para PPAR- $\alpha$ (Guerre_Millo, M y col., 2001; Tordjman, K y col., 2001) son menos vulnerables a la resistencia insulínica provocada por una dieta alta en grasas. Sin embargo, el mecanismo exacto mediante el cual interaccionan PPAR- $\alpha$ y la secreción de insulina requiere de mayores investigaciones al respecto para aclarar totalmente el panorama.

Efecto sobre las desaturasas hepáticas. A partir de los trabajos de Waters y col. (Waters, KM y Ntambi, JM, 1994) en SCD1 y de Rimoldi y col (Rimoldi, OJ y col., 2001) para el caso de la $\Delta 6$ desaturasa, y de otras investigaciones al respecto, se había demostrado el rol restaurador de la insulina sobre el nivel del ARNm y sobre la actividad de las desaturasas deprimidas en el hígado de animales diabéticos. A partir de los resultados que se muestran en la Fig. III.1 y Tabla III.4, no solo se confirman algunos de estos hallazgos sino que se agrega la demostración de este mismo efecto en la expresión del ARNm de $\Delta 5$ desaturasa.

El espectro de genes activados por el PPAR- $\alpha$ incluye varios genes encargados de la oxidación de AG. Resulta paradójico entonces el hecho de que PPAR- $\alpha$ también incremente a las desaturasas de roedores, las que son lipogénicas (Miller, CW y Ntambi, JM, 1996; Matsuzaka, T y col., 2002). En nuestro trabajo se encontró este efecto activador sobre el ARNm y la actividad enzimática de SCD1 y $\Delta 5$ desaturasa hepáticas en 
todos los lotes investigados, incluso en aquel donde la insulina ya había recuperado estos niveles deprimidos por la diabetes, con el resultado de una adición de los efectos.

Esto demuestra entonces, a partir de estos resultados, la independencia entre ambas vías de activación, la dependiente de insulina y la dependiente de PPAR-a, dado que el Fen logró llevar a cabo su activación sobre las desaturasas aun en los animales del lote diabético, en donde la insulina está ausente. Además, se evidencia un efecto aditivo de ambas vías a partir de lo que se encuentra en el lote $d+i$, con lo cual se descarta algún tipo de competencia entre estas vías de activación independientes.

Efectos sobre las composiciones de AG de membranas. Los cambios hallados en la relación entre los niveles de AG monoinsaturados/poliinsaturados en los lípidos hepáticos como consecuencia de la acción de la diabetes y la insulina se correlacionan con las alteraciones halladas en los niveles de SCD1 hepática en los diferentes lotes (Tablas III. 5 a 7), y demuestran la influencia que puede tener la diabetes y el tratamiento hormonal realizado sobre la fluidez de las membranas, parámetro involucrado en la fisiopatología de la diabetes mellitus (Attie, AD y col., 2002; Sun, Y y col., 2003).

Sin embargo, los cambios encontrados en el nivel de expresión de $\Delta 5$ desaturasa como consecuencia de la diabetes y del tratamiento con insulina no se manifiestan a nivel de las composiciones de membrana ni en la relación 20:4n-6/18:2n-6. Esta discrepancia puede deberse al menor efecto o repercusión que tiene la alteración de la expresión y actividad de $\Delta 5$ desaturasa hepática en comparación con SCD1 sobre las composiciones de ácidos grasos de membrana hepática y/o a que el 
experimento incluyó un periodo de duración de la diabetes demasiado corto.

El Fen produjo un aumento de la relación 18:1n-9/18:0 en todos los lípidos estudiados de todos los lotes investigados (Tablas III. 5 a 7). Sin embargo, esto puede deberse en gran medida al descenso del ácido esteárico (18:0) más que al aumento de oleico (18:1n-9), lo cual posiblemente es un efecto de la dieta proporcionada a los animales, la que no estaba libre de grasas, demostrando también la gran influencia que puede tener la dieta sobre las composiciones de ácidos grasos de membrana, incluso enmascarando el efecto de diferentes drogas que puedan estar utilizándose, lo que pone de manifiesto el sumo cuidado que se debe tener al intentar asociar en forma directa las composiciones de ácidos grasos de membrana con la actividad o expresión de las enzimas involucradas en su síntesis o catálisis.

En el análisis del efecto del Fen sobre la biosintesis de PUFAs, los niveles de ácido araquidónico y la relación 20:4n-6/18:2n-6 no se modificaron en ningún caso, a pesar del aumento de expresión y actividad que el Fen provocó sobre la $\Delta 5$ desaturasa. Este hecho también fue encontrado por otros autores (Guillou, H y col., 2002; Song, He W y col., 2002) quienes no hallan explicación acerca de la falta de repercusión sobre los niveles de araquidónico como consecuencia de la activación de $\Delta 5$ y $\Delta 6$ desaturasas por parte del Fen. Además, el ácido graso 22:6n-3 no se vio modificado por el tratamiento con Fen (Tablas III. 21 a 23).

La ausencia de grandes alteraciones en las composiciones lipídicas, durante los períodos estudiados, como consecuencia de la activación tanto del ARNm como de la actividad de las desaturasas a través de la administración de Fen, necesita ser explicada a través de algún mecanismo. Una explicación sería tener en cuenta los hallazgos 
de Song y col. (Song, He W y col., 2002), quienes encontraron que la activación transcripcional de las desaturasas, como consecuencia de la activación de PPAR-a, se produce después de la activación de los genes dedicados a la oxidación de ácidos grasos. Con lo cual, esos autores sugieren que la activación de las desaturasas por parte de PPAR- $\alpha$, en este caso al menos, sería la consecuencia de un mecanismo compensador que recupera los niveles de ácidos grasos disminuidos por el incremento de la $\beta$-oxidación que el mismo PPAR- $\alpha$ desencadenó. Ello llevaría a un estado final de prácticamente ninguna modificación en los niveles y proporciones de los ácidos grasos de membrana.

El Fen produjo un incremento del ácido palmítico (16:0) en todos los lipidos estudiados, lo que también es un hecho extraño que necesita un estudio específico para su resolución, porque significaría que el mismo ácido graso ingresa en un ciclo fútil de sintesis y oxidación, como ya lo discutieron Desvergne y Wahli (Desvergne, B y Wahli, W, 1999). El mismo fármaco produjo también una depresión de los niveles de ácido esteárico (18:0) en todos los casos, que según nuestros resultados no se debe a un aumento de su desaturación a oleico (18:1n9), debido a que este último no muestra un aumento concordante con lo que se hubiese esperado si así fuera. Se podría pensar en una disminución de la elongación de palmítico a esteárico, lo que justificaría bien la disminución de este y el aumento de aquel. Sin embargo Kawashima y Kozuka (Kawashima, Y y Kozuka, H, 1985) y Kudo y col. (Kudo, N y col., 2003) han hallado que la actividad enzimática de la palmitoil-CoA elongasa se incrementa en lugar de disminuir, en el hígado de ratas tratadas con clofibrato, otra droga de la misma familia que es capaz de aumentar la actividad transcripcional de PPAR- $\alpha$.

A partir de esto, se puede concluir que el aporte de los sistemas de elongación en la regulación de la biosíntesis de ácidos grasos debe 
ser investigado y analizado en conjunto con los resultados a esperar según las alteraciones de las desaturasas, ya que cuando se lo hace de forma separada se puede llegar a conclusiones erróneas.

De cualquier modo, se conoce que las especies moleculares de PC que contienen ácido palmítico (16:0) proporcionan una mayor fluidez a las membranas que las que poseen ácido esteárico (18:0) (Tricerri, MA y col., 1994), por lo que este cambio podría ser una consecuencia de la necesidad de un cambio de fluidez que podría estar siendo provocada por la acción de Fen.

\section{IV.B Análisis de las interacciones combinadas entre Insulina, T091317 y Fenofibrato}

Esta parte de la investigación tuvo como objetivo principal el estudio in vivo de las interacciones entre las vías regulatorias dependientes de insulina, de PPAR- $\alpha$, de SREBP-1c y de LXR- $\alpha$ sobre la modulación de las desaturasas y sus consecuencias sobre los niveles de AG en los lipidos de membrana. También se hizo un estudio de la influencia de estos mismos factores regulatorios sobre el sistema de elongación de ácidos grasos, específicamente sobre la enzima palmitoilCoA elongasa, y de su importancia en la determinación de las composiciones lipídicas de membrana.

Con estos objetivos, se utilizaron ratas Wistar, una parte de las cuales se hizo diabética de tipo I mediante inyección con STZ. Posteriormente se trató a los animales diabéticos con insulina y/o T091317 (T09, agonista especifico de LXR- $\alpha$ ), reservándose un lote control diabético sin tratamiento. Las ratas no diabéticas fueron separadas en lotes y se les administró T09 y/o fenofibrato (Fen, agonista de PPAR- $\alpha$ ) dejando un lote como control sin diabetes ni tratamiento. 
Análisis de las repercusiones sobre los parámetros plasmáticos. En primer lugar, se halló que el Fen provocó un aumento de la insulinemia en los animales control, en los que la secreción hormonal funciona correctamente. Este efecto, atribuido a la activación de la vía dependiente de PPAR-a, como lo demuestra el aumento de actividad de acil-CoA oxidasa en los lotes tratados con Fen (Fig. III.2), no logró disminuir los valores de glucemia en estos animales control, sugiriendo otra vez, como en un experimento anterior, una ineficiencia de esta variedad de insulina o algún efecto metabólico compensatorio.

Además, en un experimento anterior, cuando se midió la extensión de este mismo efecto causado por Fen sobre la insulinemia de animales diabéticos tratados con insulina, se encontró que en este lote la insulinemia se conserva sin cambios, lo que, junto con el conocimiento de que PPAR-a se expresa en las células $\beta$ pancreáticas (Zhou, YT y col., 1998), nos lleva a concluir que el PPAR-a estimuló la secreción de insulina y por lo tanto produjo un aumento de la misma a nivel plasmático solo en animales control sin diabetes, debido a que los demás lotes poseen un deficiencia para dicha secreción insulínica.

Por su parte, el T09 fue capaz de activar la vía dependiente de LXR-a, demostrado a través del aumento de las formas nuclear y citosólica de SREBP-1 ante el tratamiento con dicho fármaco (Fig.III 3). Sin embargo, no fue capaz de modificar la insulinemia ni la glucemia de las ratas controles ni diabéticas, ni tampoco fue capaz de disminuir la hiperinsulinemia producida por Fen en los mismos animales, demostrando una falta de interacción a nivel de la secreción de insulina entre ambos factores. Esta inefectividad de T09 en la disminución de la glucemia coincide con lo hallado por Cao y col. (Cao, G y col., 2003).

Al analizar los efectos de ambos factores sobre la colesterolemia, se observó que ni PPAR-a ni LXR-a, a través de su activación por parte 
de Fen y T09, respectivamente, fueron capaces de disminuir este parámetro plasmático cuando se administraron en forma separada. Al analizar los resultados del tratamiento conjunto, sin embargo, se encontró que la combinación de los dos fármacos logró reducir la colesterolemia, resultado en donde se hace evidente en el presente experimento una aparente interacción entre PPAR-a y LXR-a.

Efecto de los tratamientos sobre las desaturasas hepáticas. En el presente estudio se encontró que T09, a través de la activación de LXRa (Figs. III 4 y 5) produjo un incremento en la expresión y actividad de $\mathrm{SCD} 1, \Delta 6$ y $\Delta 5$ desaturasas hepáticas, tanto en animales no diabéticos como diabéticos carentes de insulina. Este hecho ya había sido demostrado pero solo para el ARNm de SCD1 (Shultz, JR y col., 2000; Chisholm, JW y col., 2003; Wang, Y y col., 2004), al cual ahora se agrega lo encontrado en este trabajo para las otras dos desaturasas.

A pesar de que T09 no requiere la presencia de insulina para provocar el incremento en los niveles de ARNm de las desaturasas, dado que lo hace tanto en animales nd como en ratas $\mathrm{d}$, la administración conjunta de ambos fármacos demuestra un efecto sinergístico sobre estos parámetros. Este efecto conjunto es fácilmente explicable debido a la conocida estimulación de LXR-a sobre la expresión de SREBP-1c (Chen, G y col., 2004) junto a la también conocida intervención de la insulina en el procesamiento hidrolítico de maduración del de SREBP1c (Hegarty, BD y col., 2005).

Este hecho también indica que, según nuestros resultados, y teniendo en cuenta que en animales diabéticos existe una inhibición de la maduración de SREBP-1c debido a la falta de estimulación de SCAP por parte de la insulina, LRX-a estaría produciendo un aumento de transcripción y de actividad enzimática de las tres desaturasas 
hepáticas en forma independiente de la presencia de insulina y/o SREBP-1c, posiblemente haciéndolo directamente sobre los promotores de los genes de las desaturasas, aunque todavia no se ha encontrado ningún sitio de unión para LXR-a en ninguno de ellos. Previamente, a la activación transcripcional de SCD1 por parte de LXR-a en forma directa, se le había asignado un rol regulatorio a través del cual SCD1 aumenta la biosíntesis de AG monoinsaturados a ser usados en la esterificación de colesterol en exceso. Esto se correlacionaría con el hecho de que el colesterol no induce a $\Delta 5$ y $\Delta 6$ desaturasas, las cuales desviarian el destino de estos nuevos AG monoinsaturados. Sin embargo, nuestros resultados demuestran que la activación de la vía dependiente de LXR-a, en forma SREBP-1c-independiente, no solo produce un incremento de la expresión de SCD1, sino también de las otras dos desaturasas. Por consiguiente, el modelo de regulación metabólica directa de LXR-a sobre las desaturasas requiere aún de mayores investigaciones al respecto para su total dilucidación.

La gran activación que ocurre sobre la transcripción de SCD1, y de las $\Delta 6$ y $\Delta 5$ desaturasas no se traslada a las actividades respectivas. Existe una estimulación de las mismas como consecuencia del tratamiento combinado, pero no llega a ser tan importante como en el caso de los ARNm, posiblemente debido a alguna regulación posttraduccional, que como se sabe se ha encontrado que es capaz de regular los niveles finales de actividad enzimática (Mziaut, H y col., 2000, Tiku, PE y col., 1996).

Por su parte, la activación de PPAR-a a través de Fen produjo un aumento de los ARNm de SCD1 y $\Delta 5$ desaturasa, en animales controles y en animales diabéticos (ver III. A). el grupo de Clarke demostró (Tang, C y col., 2003) la activación de la transcripción de $\Delta 6$ desaturasa hepática a través de la unión del dímero PPAR-a/RXR al promotor del 
gen luego de la activación de la vía mediante WY14643, otro agonista de PPAR-a. Matzusaka y col. (Matzusaka, T y col., 2002) y Song y col. (Song, He W y col., 2002) también encontraron un comportamiento similar de la $\Delta 6$ desaturasa ante la administración de fenofibrato. El hecho de que Fen produzca un aumento de la expresión de las desaturasas tanto en animales nd como en $\mathrm{d}$, habla de una independencia entre las vías dependientes de insulina y de PPAR-a, el que actuaria directamente sobre los promotores de les tres desaturasas hepáticas.

En los casos en donde se administró Fen a animales tratados simultáneamente con T09, se encontró que los efectos sobre los valores de inducción de los ARNm y de las actividades de las desaturasas no son aditivos, en comparación con las estimulaciones encontradas para T09 y Fen solos (Fig.III 4 y III.5). La explicación de este hecho es probable que sea la competencia que se estableceria por parte de las vías dependientes de PPAR-a y LXR-a por el RXR disponible en la célula, debido a que ambos factores de transcripción, PPAR-a y LXR-a, deben formar heterodimeros obligados con RXR para poder producir sus efectos activadores sobre sus genes blanco.

También se encontró el mismo resultado no aditivo entre Fen y T09 sobre la expresión de $\Delta 6$ desaturasa hepática, cuando se midió la cantidad total de esta proteína microsomal mediante Western blot (Fig. III.6).

Ya se habia comentado anteriormente en forma breve la creciente importancia que posee la regulación de las enzimas elongasas de ácidos grasos como otro mecanismo regulatorio sobre la biosintesis de ácidos grasos insaturados. De acuerdo a los resultados del presente trabajo, existiría una interregulación de la elongación de ácidos grasos por parte de insulina, PPAR-a, SREBP-1c y LXR-a, dado que se encontró que 
estos mismos factores son capaces de modificar el nivel de actividad de palmitoil-CoA elongasa, y con la misma tendencia general que lo encontrado para las desaturasas (Fig.III 7).

Efecto sobre las composiciones de ácidos grasos de membrana. En la Tabla III.8 se muestra la influencia del efecto de la depresión producida por la diabetes sobre la expresión y actividad desaturante, y del efecto de la activación producida sobre estos parámetros por parte de insulina, PPAR-a y LXR-a, sobre las composiciones de ácidos grasos hepáticas.

En general, el efecto depresor sobre la expresión de la desaturasas provocado por la diabetes tiene la obvia consecuencia de producir cambios en la composición de ácidos grasos del hígado y en otros tejidos conduciendo a importantes anormalidades fisiológicas. Estos cambios pueden producir un desbalance de la relación entre ácidos grasos desaturados/saturados en los lipidos de membrana (Brenner, RR, 1984). Resultados previos demuestran estas alteraciones en lipidos microsomales totales de hígado (Faas, FH y Carter WJ, 1983) y en otros tejidos (Igal, RA y col., 1991), especialmente en lo que se refiere a la disminución de ácido araquidónico y al aumento de linoleico, provocada por la disminución de actividad de $\Delta 6$ y $\Delta 5$ desaturasas, a pesar de que las alteraciones debidas a la disminución de actividad de $\Delta 9$ desaturasa no siempre son evidentes. Además, estas alteraciones provocadas por la diabetes son capaces de modificar la fluidez de la membrana microsomal y de otras membranas, pudiendo conducir a alteraciones de las interacciones lipido-proteina en estas zonas (Brenner, RR y col. 2000).

Sin embargo en nuestros experimentos, el efecto depresor del ARNm de las desaturasas y de la actividad desaturante producido por la 
patología diabética no se trasladó a las composiciones lipídicas. Debido a que la duración del periodo de diabetes en los animales de este experimento fue relativamente corta (alrededor de 15 días) en comparación con otros trabajos (por ejemplo 30 dias de diabetes o más), concluimos que existe un umbral de tiempo que debe transcurrir antes de que las composiciones de membrana reflejen los cambios producidos sobre el metabolismo de las desaturasas y que la duración del período diabético en este experimento no fue suficiente para que así ocurra.

Un resultado llamativo, el cual coincide con lo encontrado por otros autores (Hurtado de Catalfo, GE, y de Gomez Dumm, I, 1998; Faas, FH y Carter WJ, 1983; Chanussot, B y col., 1997), es el hecho de que a pesar de que $\Delta 6$ y $\Delta 5$ desaturasas muestran, en general, un descenso de expresión y actividad como consecuencia de la diabetes de tipo I, el ácido graso 22:6n-3 se encuentra aumentado en las composiciones lipídicas de membrana, tanto en los experimentos del punto III.a como III.B. A partir de los trabajos del grupo de Sprecher (Sprecher, H y col., 1995) se considera descartado que en la vía de sintesis del 22:6n-3 participe una $\Delta 4$ desaturasa, la que anteriormente se habia hipotetizado como activada como consecuencia de la patología diabética y como responsable del aumento de este ácido graso. También se pensó en una nueva isoenzima de $\Delta 6$ desaturasa, con una regulación distinta, a la cual se le pudiera adjudicar este hallazgo, pero cuya existencia finalmente nunca fue probada. Brenner y col. (Brenner, RR y col. 2000) sugieren que lo que en realidad podría estar sucediendo es que el aumento de 22:6n-3 que se encuentra en los animales diabéticos se deba a una disminución de su oxidación en lugar de a un aumento de síntesis, explicación que se adecua bien a nuestro caso en donde las medidas de actividad desaturante indicarian una sintesis disminuida de AG como el araquidónico, lo que llevaría a una disminución de 
oxidación peroxisomal a través de una desactivación de la vía dependiente de PPAR-a. Sin embargo, estaría también descartada esta última hipótesis, debido a que la medida de acil-CoA oxidasa peroxisomal indicó un aumento en el caso de los animales diabéticos, posiblemente debido a la ausencia de su inhibidor insulina. Por consiguiente, no se puede pensar en una mayor oxidación por parte de esta enzima. En consecuencia, sigue quedando sin respuesta este extraño comportamiento del ácido graso 22:6n-3 frente a la diabetes de tipo insulino-dependiente.

En el caso del tratamiento simultáneo con T09 e insulina sobre las ratas diabéticas, en donde se habia producido un gran sinergismo a nivel de los ARNm de las desaturasas, se encontró solo un aumento de los ácidos monoenoicos palmitoleico y oleico, pero no se observaron cambios para los ácidos grasos cuya biosíntesis es dependiente de $\Delta 6 \mathrm{y}$ $\Delta 5$ desaturasa. Además, debido a que este efecto no se encontró en los lotes diabético y no diabético, tratados con T09, los resultados sugieren que la supuesta vía de activación directa de LXR-a sobre las desaturasas (independiente de SREBP-1c) no tendría un efecto e importancia suficientes como para hacerse evidente sobre las composiciones de ácido grasos en el corto tiempo de experimentación que solo alcanzó 7 días.

PPAR-a, por su parte, ante la activación provocada por la administración de Fen (demostrado por el aumento acil-CoA oxidasa), no solo produjo una inducción del ARNm y de la actividad de SCD1, sino que también provocó un aumento de la actividad de la palmitoilCoA elongasa. Los cambios provocados por la activación de PPAR-a se vieron reflejados en una disminución de ácido esteárico junto a un aumento de ácido palmítico. La disminución de ácido esteárico junto al aumento de oleico y palmitoleico se adjudican en general a un 
incremento de actividad de la SCD1. El aumento de palmítico, en cambio, es dificil de entender, como ya se discutió anteriormente, debido a que la medida de actividad de la palmitoil-CoA elongasa muestra un aumento. Nuestra hipótesis es que, a pesar de que el PPARa está directamente relacionado con un aumento del catabolismo de los AG, el mismo es capaz de activar una ruta de síntesis y esterificación de palmítico que serviría como punto de partida para compensar la disminución general de AG que se produce por la incrementada oxidación de los mismos. Ya se comentó anteriormente, además, la repercusión que podría tener sobre la fluidez de membrana el cambio de 18:0 a 16:0 que ocurre como consecuencia de la acción del Fen. Otra posibilidad sería que los cambios que en este trabajo se encuentran en las composiciones de ácidos grasos en general sean tan pequeños como para que la influencia de los AG provenientes de la dieta no se pueda descartar.

Por último, el tratamiento con Fen, a pesar de haber producido un incremento de la actividad de las desaturasas, provocó una disminución de los PUFAs de la serie n-3 20:5, 22:5 y 22:6, tal como se observa habitualmente con algunos tratamientos, lo que requiere una mayor investigación al respecto.

\section{IV.C Ratas SAC}

La diabetes de tipo II es la forma más común de diabetes y ha sido investigada durante muchos años (McGarry, JD, 2002; Shulman, GI, 2000). Los estudios han demostrado que las alteraciones en el metabolismo de carbohidratos y de lípidos contribuyen de manera fundamental en el desarrollo de patología (Shimomura, I y col., 2000). A 
pesar de que se considera que la enfermedad tiene una base poligenética (Elbein, SC, 1997), los factores ambientales también contribuyen en el proceso de la enfermedad. Sin embargo, el mecanismo preciso a través del cual actúan estos factores aún necesita de numerosas investigaciones para ser aclarado.

Para poder realizar una comparación entre los efectos de la diabetes de tipo I y de tipo II sobre el metabolismo de las enzimas desaturantes de ácidos grasos hepáticas y sobre la repercusión de sus alteraciones en las composiciones de ácidos grasos de membrana, comenzamos a estudiar el comportamiento de animales Wistar que desarrollan una diabetes por resistencia a la acción de la insulina a través de la administración, durante 6 meses, de una dieta suplementada con sacarosa al $63 \% \mathrm{p} / \mathrm{p}$ (animales SAC), en comparación con animales que recibieron una dieta control suplementada con almidón.

Dependiendo del tiempo de administración de esta dieta suplementada con sacarosa, se ha identificado un proceso con tres etapas (Chicco, A y col., 2000). La primera, denominada Período de Inducción (3-5 semanas), se caracteriza por aumento de TG, AG libres e insulina plasmáticos, con tolerancia a la glucosa moderadamente alterada. La etapa dos (5-8 semanas) o Período de Adaptación, muestra una normalización espontánea de los parámetros antes mencionados, mientras que la tercera etapa (luego de 8 semanas) resulta nuevamente en niveles elevados de trigliceridemia, glucemia y AG libres circulantes, ahora con normoinsulinemia y tolerancia a la glucosa severamente alterada (resistencia a la insulina).

Efecto sobre los parámetros plasmáticos. 
Luego de 6 meses de alimentación especial, los animales mostraron desviaciones se sus parámetros plasmáticos que demuestran que como consecuencia del tratamiento los mismos se hallaban en el denominado Período de Recurrencia dentro del desarrollo de la enfermedad (Tabla III.9). Estos resultados ponen de manifiesto una etapa en la que el páncreas ha comenzado a disminuir su producción de insulina, lo que sumado a la resistencia antes generada a la acción de la hormona, produce una hiperglucemia. También es importante agregar que el grupo de Lombardo (Lombardo, YB y col., 1996) halló que una dieta rica en sacarosa durante 30 semanas incrementa tanto el número de islotes como la proporción del área correspondiente a las células beta pancreáticas, pero sin que la producción de insulina se incremente proporcionalmente, por lo que se sugirió que las nuevas células beta tendrian algún tipo de daño producido por la gran demanda de insulina a causa de la resistencia a su acción.

Efecto sobre SCD1 hepática y la biosintesis de AG monoinsaturados. Luego de 6 meses de dieta rica en sacarosa, se encontró una elevación de la expresión y actividad de SCD1 (Fig. III.8 y Tabla III.10). Correlativamente con estos cambios, los cocientes 16:1/16:0 y 18:1/18:0 se mostraron aumentados para las fracciones homogenato hepático, microsomas hepáticos y fosfolipidos y TG microsomales hepáticos (Tabla III. 11 a 13).

En estos animales, la insulinemia se mantiene en niveles prácticamente normales. Por lo tanto, estos resultados no solo demuestran una falta de correlatividad, en este modelo de diabetes de tipo II, entre el comportamiento de SCD1 y el nivel de insulinemia, sino que además ponen de manifiesto que la resistencia a la acción de la insulina no afecta de manera negativa a la expresión y actividad de la 
desaturasa, como era de esperar a partir del conocimiento del rol activador que tiene esta hormona.

Efecto sobre $\Delta 6$ y $\Delta 5$ desaturasas hepáticas y la biosintesis de PUFAs. Con respecto a los niveles de ARNm, solo se midió el de la $\Delta 6$ desaturasa, debido a que en el momento del experimento todavía no había sido clonado el $\mathrm{ADNc}$ de la $\Delta 5$ desaturasa, con lo que no estábamos en condiciones de sintetizar una sonda correspondiente para la medida del nivel del ARNm de esta enzima. El parámetro medido registró un incremento significativo al cabo de 6 meses con suplementación de sacarosa al 63\% en la dieta de los animales (Fig. III. 8).

En cuanto a las actividades enzimáticas, $\Delta 6$ y $\Delta 5$ desaturasas hepáticas también mostraron incrementos significativos para los animales tratados con respecto a los controles (Tabla III.10)

El cambio medido para las desaturasas hepáticas fue registrado en las composiciones de AG de membrana con un aumento del cociente 20:4n-6/18:2n-6 para todas las fracciones lipídicas analizadas (Tablas III. 11 a 13). A pesar del incremento en el nivel de las actividades $\Delta 6$ y $\Delta 5$ desaturasas, el ácido graso DHA (22:6n-3) estuvo disminuido en todos los lipidos estudiados.

En el análisis correspondiente al metabolismo de $\Delta 5$ y $\Delta 6$ desaturasas hepáticas, se pueden extraer conclusiones similares a las extraídas para el caso de SCD1. O sea, a pesar de la normoinsulinemia y de la resistencia a la insulina provocada en los animales tratados como consecuencia de la dieta con sacarosa, tanto la expresión como la actividad de ambas enzimas se hallan activadas.

La modulación impuesta por las desaturasas no siempre controla el nivel de DHA (Brenner, RR y col., 2000). Se cree que esta 
discrepancia podría deberse a los pasos adicionales de sintesis que se requieren para llegar hasta este ácido graso, los que involucran, además de las desaturaciones y elongaciones entre 18:3n-3 y los PUFAs de 20 átomos de carbono, a otras reacciones de elongación microsomales, e incluso una reacción de $\beta$-oxidación peroxisomal. El ácido docosapentaenoico (22:5n-6), el que también requiere de pasos adicionales para su síntesis que involucran una oxidación peroxisomal, se halla sin embargo incrementado en todas las medidas realizadas como consecuencia de la diabetes, por lo que esta hipótesis perdería fuerza. Este tema, como ya se discutió en mayor detalle anteriormente en este trabajo de tesis, el comportamiento del ácido graso DHA requiere de mayores investigaciones al respecto.

De todos modos, cuando se comparan los efectos de este tipo de diabetes (tipo II) con lo encontrado en trabajos anteriores respecto de lo que ocurre en el caso de la diabetes experimental de tipo I, se encuentra que el antagonismo que aparece en el comportamiento de las desaturasas y en las composiciones correspondientes de ácidos grasos de membrana, también se hace evidente en el hecho de que, mientras que en la diabetes de tipo I el 22:6n-3 aumenta y la expresión de $\Delta 5$ y $\Delta 6$ desaturasas disminuye (Brenner, RR y col., 2000; Brenner, RR, 2003), en la diabetes de tipo II el nivel del ácido graso disminuye mientras que la expresión de las enzimas aumenta. Esta disminución de DHA en los animales alimentados con sacarosa es un factor importante en la inducción de la patología debido a que se ha encontrado que el reemplazo del aceite de maíz por aceite de hígado de bacalao (rico en DHA) en la dieta de los animales produce una disminución de la hipertrigliceridemia y de los altos niveles de AG libres, a la vez que mejora la sensibilidad periférica a la insulina (D’Alesandro, ME y col., 2000). 
Ante la falta de respuesta regulatoria de las tres desaturasas a los niveles de insulina, se podría pensar en la acción de otras hormonas que podrian estar ejerciendo su regulación en estos casos, como glucocorticoides, mineralocorticoides y testosterona. Sin embargo, esto sería difícil de explicar dado que las mismas modulan a SCD1 en forma positiva, y a la vez, desactivan a $\Delta 6$ y $\Delta 5$ desaturasas (Brenner, RR, 2003; Brenner, RR y col., 2001). Se ha demostrado que una dieta rica en sacarosa modifica el nivel del ARNm de PPAR-a en hígado (Nagai, Y y col., 2002) mientras que produce un incremento de la expresión de SREBP-1c (Matsuzaka, T y col., 2002), por lo que evidentemente se deben tener en cuenta estas vías de activación para ver lo que sucede con la expresión de las desaturasas ante la falta de regulación por parte de insulina.

\section{IV.D Ratas eSS}

Efecto de la diabetes sobre los parámetros plasmáticos. En estudios previos (Gagliardino, J.J., y col., 1993 ,Martinez, SM y col., 1988) se ha demostrado que los animales eSS desarrollan, desde una edad temprana, hiperglucemia en ayunas, prueba de tolerancia a la glucosa alterada e hiperinsulinemia. La hiperglucemia llega a sus niveles más altos alrededor del mes 10 de edad para los machos, mientras que la insulinemia comienza a descender lentamente a partir de ese momento, hasta llegar a valores prácticamente normales a los 15-18 meses de edad.

Además de estos parámetros, el estudio morfológico de los islotes pancreáticos (Gomez Dumm, CL y col., 1990) también demostró una arquitectura alterada de los mismos, con fibrosis, sugiriendo una hiperplasia de las células $\beta$ a los 6 meses de edad, mientras que, ya a 
los 18 meses, se encontraron lesiones que evidenciaron una capacidad celular para la secreción de insulina disminuida o ausente. El conjunto de estos hallazgos condujo a la conclusión de que estos animales desarrollan un síndrome diabético de tipo insulino independiente, compensado alrededor de los 6 meses de vida, edad de los animales elegidos para este experimento, con un aumento de la secreción de insulina.

Nuestros resultados a nivel de los parámetros plasmáticos fueron similares a los encontrados por Martinez et al. (Martinez, SM y col., 1988) mostrando hipertrigliceridemia, hiperglucemia junto con un aumento de los triglicéridos circulantes, en comparación con animales control de la misma edad y sexo, con lo que podemos afirmar que las ratas eSS presentaban signos de estar en la etapa de resistencia insulínica con compensación parcial mediante el aumento antes mencionado de la insulina circulante.

Efecto de la patología sobre las desaturasas hepáticas. Se conoce desde hace tiempo (Gellhorn, A y Benjamin, W, 1964 Mercuri, O y col., 1966) que la insulina es capaz de recuperar la actividad y el nivel del ARNm de SCD1, $\Delta 6$ y $\Delta 5$ desaturasas disminuidos por una patología diabética de tipo I (insulino dependiente). Sin embargo, a pesar de que en estos animales eSS se ha confirmado la existencia de un síndrome diabético con resistencia a la acción de la insulina, nuestros resultados demostraron un aumento de expresión y actividad de SCD1, con valores para $\Delta 6$ y $\Delta 5$ desaturasas invariables, cuando en realidad lo que se hubiese esperado en principio hubiese sido una disminución de los parámetros antes mencionados debido a la resistencia de la acción activadora de la insulina (Fig.III 9, Tabla III.14). 
Por lo tanto, en este modelo diabético de tipo II, al igual que en el modelo SAC, es evidente que existen otros factores que actúan sobre la expresión de las desaturasas hepáticas que realizan el control principal de la regulación de las mismas cuando la insulina no puede ejercer su acción. Probablemente sean el PPAR-a y el SREBP-1c quienes en este caso, debido a la desregulación de las vias metabólicas que involucran a TG y AG libres, que a su vez regulan la actividad de dichos factores de transcripción, toman a su cargo el control principal de la regulación de las desaturasas.

El hecho de que el ARNm y la actividad de SCD1 se encuentre aumentada mientras que las medidas correspondientes para $\Delta 6$ y $\Delta 5$ desaturasas se muestran invariables, evidenciaria una respuesta diferencial que está de acuerdo con el conocimiento general que sugiere que la SCD1 suele responder más rápidamente y en mayor magnitud a estimulos activadores y desactivadores que las otras dos desaturasas.

Consecuencias sobre las composiciones lipidicas. El aumento de expresión de SCD1 se correlacionó con aumentos de ácido oleico (18:1n-9) y de los indices 18:1n-9/18:0 y 16:1/16:0, tanto para los lipidos microsomales hepáticos (Tabla III.15) como para la fosfatidilcolina microsomal hepática (Tabla III.16). En este último caso también se observó un aumento de 18:1n-7.

Debido a que, a partir de trabajos de nuestro laboratorio (Brenner, RR, 2003) y de otros, se sabe que las modificaciones en los fosfolipidos microsomales, particularmente en la fosfatidilcolina, son buenos sensores de los cambios en la actividad de las reacciones de desaturación, los datos de las Tablas III.15 y 16 confirmarian el aumento de actividad de SCD1. A su vez, los cambios en las composiciones lipídicas involucran alteraciones en las propiedades 
estructurales y biofisicas de las membranas. El aumento de la proporción de ácidos grasos monoinsaturados/saturados en las membranas de los animales eSS favorecería un aumento en la proporción de dominios cristalinos líquidos más desordenados, lo que conduce a un aumento de la fluidez y de la permeabilidad de dichas membranas (Sun, Y y col., 2003), efectos que podrian estar intimamente relacionados con el desarrollo de la patología diabética.

Además, la ausencia de incremento en la proporción de ácido araquidónico (20:4n-6) y del índice 20:4n-6/18:2n-6 que se muestra en las Tablas III.15 y 16, está de acuerdo con los datos del nivel de ARNm y de la actividad enzimática de $\Delta 6$ y $\Delta 5$ desaturasas.

Comparando los resultados obtenidos en el análisis de los animales eSS y SAC para el metabolismo de las desaturasas hepáticas, se observa un patrón de comportamiento que en general es opuesto a lo que se encuentra en los casos de diabetes tipo I, en donde el ARNm y la actividad de dichas enzimas están disminuidos.

El incremento de actividad $\Delta 9$ desaturante también podría ser visto como una vía de escape a la apoptosis, por parte de las células hepáticas, que podría inducirse como consecuencia del aumento de AG libres, particularmente del ácido palmítico, transformándose en oleico y canalizándose de esta forma hacia la aumentada sintesis de TG (Listenberger, LL y col., 2003). 


\section{IV.E Conclusiones}

Durante el desarrollo del presente trabajo de tesis, las principales conclusiones obtenidas fueron los siguientes:

1- Análisis del aporte de diferentes vías de activación a la regulación de las desaturasas de ácidos grasos hepáticas

a) La activación de PPAR-a se traduce en un incremento del ARNm y actividad enzimática de $\operatorname{SCD} 1, \Delta 6$ y $\Delta 5$ desaturasas hepáticas. El efecto activador de PPAR-a sobre el metabolismo de las desaturasas ocurre en forma independiente a la presencia de insulina, debido a que se lo encuentra en animales normales o con diabetes por insuficiencia de la hormona, pudiendo actuar ambas vías en forma aditiva.

b) El PPAR-a activado, mediante el uso de su agonista específico Fen, es capaz de aumentar la secreción de insulina, pero sin que este aumento afecte los niveles de glucemia de los animales tratados con Fen.

c) La activación de la expresión de las enzimas desaturantes hepáticas mediada por PPAR-a (Fen) en general no afecta inmediatamente a las composiciones lipídicas de membrana siendo esto probablemente la consecuencia de la activación de dos mecanismos que se oponen, el incremento de la $\beta$-oxidación de ácidos grasos y el aumento de actividad de las desaturasas hepáticas.

d) El fármaco T091317, agonista específico de LXR-a, es capaz de activar la expresión y actividad de las tres enzimas desaturantes de ácidos grasos hepáticas. Este efecto es insulino-independiente, debido a que también se produce en animales diabéticos de tipo I sin tratamiento 
con insulina. Además, como en dichos animales se conoce que está afectada la maduración hidrolítica de SREBP-1c, intermediario entre la acción de LXR-a y las desaturasas, podría existir un efecto directo del heterodímero LXR-a/RXR sobre los promotores de las desaturasas hepáticas, lo que aún resta ser demostrado cabalmente.

e) El tratamiento simultáneo con Fen (activador de PPAR-a) y T09 (activador de LXR-a) demostró una interacción entre estas vías de activación de las desaturasas hepáticas, posiblemente producida a través de una competencia por el RXR presente en el sistema, lo que no permite activar a las desaturasas hepáticas más allá de un cierto límite.

f) Los mismos factores, PPAR-a, SREBP-1c y LXR-a, que son capaces de modular a las desaturasas hepáticas en el estudio de las vías de activación antes mencionadas, también modulan la actividad de por lo menos una enzima perteneciente al sistema de elongación de ácidos grasos, produciéndolo con el mismo patrón general de comportamiento.

g) Los efectos producidos por la diabetes de tipo I sobre las desaturasas y sus efectos metabólicos, necesitan de un cierto tiempo para hacerse evidentes en las composiciones lipídicas de las membranas, conclusión que seguramente se puede trasladar a otros modelos de diabetes y tratamientos correspondientes. 
Fig. IV.1: esquema de las distintas vías de regulación de las desaturasas hepáticas en donde, a partir del aporte de nuestros resultados y de otros, se pueden observar las rutas de regulación con la participación de insulina, PPAR-a, SREBP-1c, LXR-a y RXR.

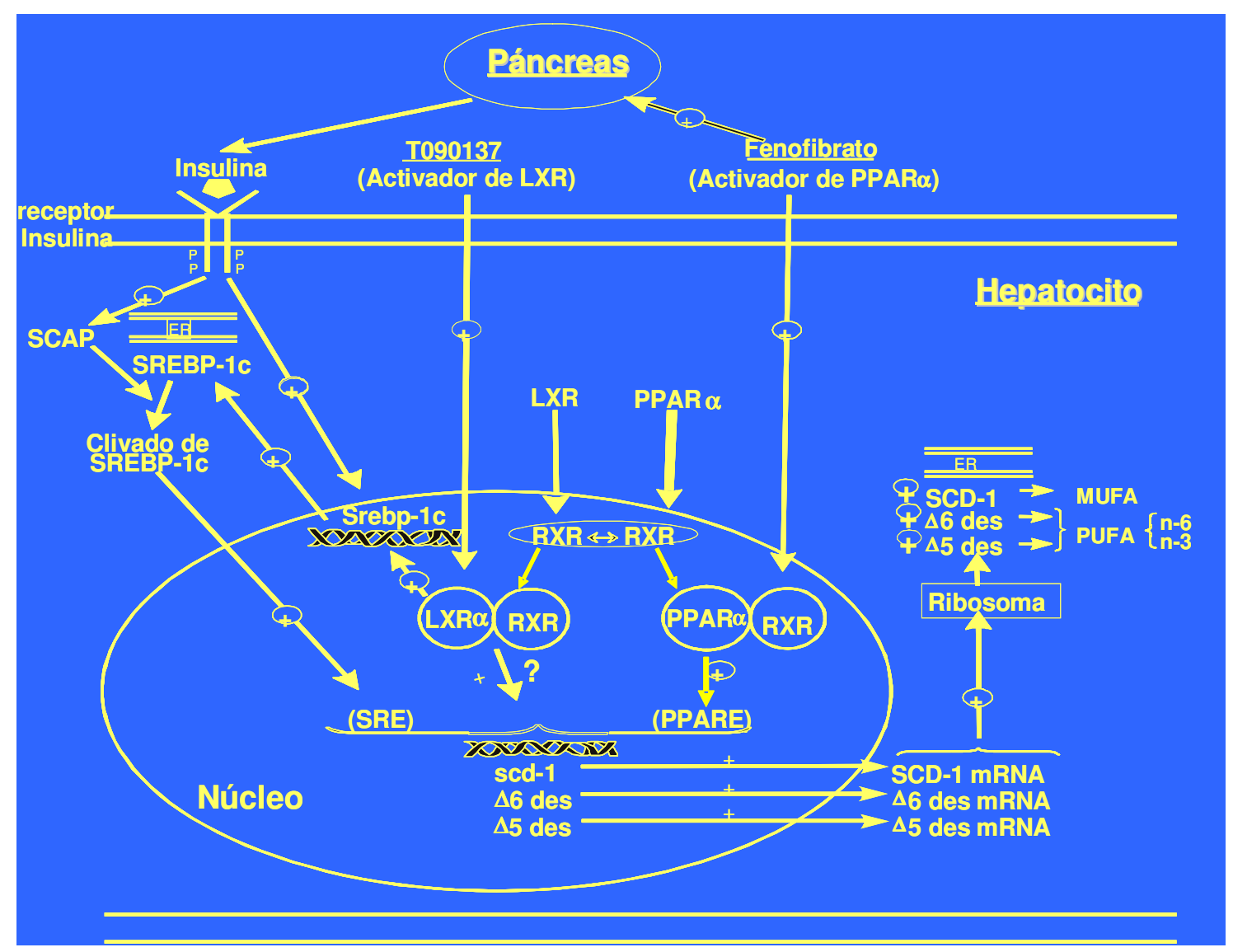

2- Análisis de modelos de diabetes de tipo II y comparación con modelo de diabetes de tipo I

a) El estudio de los modelos de diabetes de tipo II estudiados, eSS y el desarrollado a partir de una dieta rica en sacarosa, SAC, demostró que las desaturasas de ácidos grasos hepáticas SCD1 (isoforma hepática de $\Delta 9) \Delta 6$ y $\Delta 5$ no alteran su actividad como consecuencia de la incrementada resistencia a la acción de la insulina, debido a que en ninguno de los casos se observa una disminución del nivel de ARN y/o actividad de las mismas, por lo que se considera que en los modelos de 
diabetes de tipo II sería otro factor el que se hace cargo de la regulación principal de las desaturasas. El mismo probablemente sea el PPAR-a.

b) El comportamiento de las desaturasas hepáticas, SCD1, $\Delta 6$ y $\Delta 5$ que ocurre en la diabetes de tipo II, en general se opone a lo que se encuentra en los modelos diabéticos de tipo I, en donde parámetros como la expresión y actividad de estas enzimas se encuentran generalmente disminuidos.

c) Las composiciones de AG de membrana de hígado se correlacionan bien con las alteraciones encontradas en las desaturasas, siempre y cuando la duración del tiempo desde el establecimiento de la patología sea lo suficientemente largo, afectando la fluidez y la estructura de las membranas, hecho que puede estar relacionado con la fisiopatologia de la enfermedad.

d) La oposición encontrada en el comportamiento de las desaturasas hepáticas entre ambos tipos de diabetes se traslada a las proporciones de AG correspondientes en los fosfolípidos de membrana hepáticos.

e) El ácido graso DHA (22:6n-3) responde en todos los modelos estudiados, tanto de diabetes tipo I como tipo II, a la inversa de lo que se deduciría a partir de los cambios en la expresión y actividad de las enzimas desaturantes, hecho que requiere de mayores investigaciones al respecto. 


\section{Referencias}

Aki, T.; Shimada, Y.; Inagaki, K.; Higashimoto, H.; Kawamoto, S.; Shigeta, S.; Ono, K.; Suzuki, O. Biochem.Biophys.Res.Commun. 1999, 255(3), 575-579.

Attie, A. D.; Krauss, R. M.; Gray-Keller, M. P.; Brownlie, A.; Miyazaki, M.; Kastelein, J. J.; Lusis, A. J.; Stalenhoef, A. F.; Stoehr, J. P.; Hayden, M. R.; Ntambi, J. M. J.Lipid Res. 2002, 43(11), 1899-1907.

Behrouzian, B.; Savile, C. K.; Dawson, B.; Buist, P. H.; Shanklin, J. J.Am.Chem.Soc. 2002, 124(13), 3277-3283.

Bergmeyer, H.V. 1974 en: H.V. Bergmeyer (Ed.), Methods for Determination of Metabolites in Methods of Enzymatic Analysis, second ed, Academic Press, New York,

Biddinger, S. B.; Miyazaki, M.; Boucher, J.; Ntambi, J. M.; Kahn, C. R. Diabetes 2006, 55(7), 2032-2041.

Braissant, O.; Foufelle, F.; Scotto, C.; Dauca, M.; Wahli, W. Endocrinology 1996, 137(1), 354-366.

Brenner RR, Peluffo RO, Mercuri OF y Restelli MA. 1968 Am. J Physiol. 215:63-70.

Brenner, R. R. Prog.Lipid Res. 1984, 23(2), 69-96.

Brenner, R. R.; Bernasconi, A. M.; Garda, H. A. Prostaglandins Leukot.Essent.Fatty Acids 2000, 63(3), 167-176.

Brenner, R. R.; Ayala, S.; Garda, H. A. Lipids 2001, 36(12), 1337-1345.

Brenner, R. R.; Bernasconi, A. M.; Gonzalez, M. S.; Rimoldi, O. J. Lipids 2002, 37(4), 375-383.

Brenner, R. R. Prostaglandins Leukot.Essent.Fatty Acids 2003, 68(2), 151-162.

Brenner, R. R. Rev. Farm. 2006 148(1) 33-49

Briggs, M. R.; Yokoyama, C.; Wang, X.; Brown, M. S.; Goldstein, J. L. J.Biol.Chem. 1993, 268(19), 14490-14496.

Brown, M. S.; Goldstein, J. L. Cell 1997, 89(3), 331-340.

Cao, G.; Liang, Y.; Broderick, C. L.; Oldham, B. A.; Beyer, T. P.; Schmidt, R. J.; Zhang, Y.; Stayrook, K. R.; Suen, C.; Otto, K. A.; Miller, A. R.; Dai, J.; Foxworthy, P.; Gao, H.; Ryan, T. P.; Jiang, X. C.; Burris, T. P.; Eacho, P. I.; Etgen, G. J. J.Biol.Chem. 2003, 278(2), 1131-1136.

Cases, S.; Smith, S. J.; Zheng, Y. W.; Myers, H. M.; Lear, S. R.; Sande, E.; Novak, S.; Collins, C.; Welch, C. B.; Lusis, A. J.; Erickson, S. K.; Farese, R. V., Jr. Proc.Natl.Acad.Sci.U.S.A 1998, 95(22), 1301813023.

Cases, S.; Novak, S.; Zheng, Y. W.; Myers, H. M.; Lear, S. R.; Sande, E.; Welch, C. B.; Lusis, A. J.; Spencer, T. A.; Krause, B. R.; Erickson, S. K.; Farese, R. V., Jr. J.Biol.Chem. 1998, $273(41)$, 26755-26764.

Cases, S.; Stone, S. J.; Zhou, P.; Yen, E.; Tow, B.; Lardizabal, K. D.; Voelker, T.; Farese, R. V., Jr. J.Biol.Chem. 2001, 276(42), 3887038876.

Catalá, A.; Nervi, A. M.; Brenner, R. R. J.Biol.Chem. 1975, 250(18), 7481-7484.

Chanussot, B.; Asdrubal, P.; Huang, Y. S.; Poisson, J. P. Prostaglandins Leukot.Essent.Fatty Acids 1997, 57(6), 539-544. 
Chawla, A.; Repa, J. J.; Evans, R. M.; Mangelsdorf, D. J. Science 2001, 294(5548), 1866-1870.

Chen, G.; Liang, G.; Ou, J.; Goldstein, J. L.; Brown, M. S. Proc.Natl.Acad.Sci.U.S.A 2004, 101(31), 11245-11250.

Chicco, A.; Basabe, J. C.; Karabatas, L.; Ferraris, N.; Fortino, A.; Lombardo, Y. B. Metabolism 2000, 49(10), 1346-1351.

Chisholm, J. W.; Hong, J.; Mills, S. A.; Lawn, R. M. J.Lipid Res. 2003, 44(11), 2039-2048.

Cho, H. P.; Nakamura, M. T.; Clarke, S. D. J.Biol.Chem. 1999, 274(1), 471-477.

Cho, H. P.; Nakamura, M.; Clarke, S. D. J.Biol.Chem. 1999, 274(52), 37335-37339.

Clarke, S. D.; Jump, D. B. Annu.Rev.Nutr. 1994, 14 83-98.

Clarke, S. D.; Baillie, R.; Jump, D. B.; Nakamura, M. T. Ann.N.Y.Acad.Sci. 1997, 827 178-187.

Cohen, P.; Miyazaki, M.; Socci, N. D.; Hagge-Greenberg, A.; Liedtke, W.; Soukas, A. A.; Sharma, R.; Hudgins, L. C.; Ntambi, J. M.; Friedman, J. M. Science 2002, 297(5579), 240-243.

D'Alessandro, M. E.; Chicco, A.; Karabatas, L.; Lombardo, Y. B. J.Nutr.Biochem. 2000, 11(5), 273-280.

D'Andrea, S.; Guillou, H.; Jan, S.; Catheline, D.; Thibault, J. N.; Bouriel, M.; Rioux, V.; Legrand, P. Biochem.J. 2002, 364(Pt 1), 4955.

de Alaniz, M. J.; Marra, C. A. Prostaglandins Leukot.Essent.Fatty Acids 2003, 68(2), 163-170.

de Urquiza, A. M.; Liu, S.; Sjoberg, M.; Zetterstrom, R. H.; Griffiths, W.; Sjovall, J.; Perlmann, T. Science 2000, 290 (5499), 2140-2144.

de, G. D., I; de Alaniz, M. J.; Brenner, R. R. J.Lipid Res. 1975, 16(4), 264-268.

de, G. D., I; de Alaniz, M. J.; Brenner, R. R. Lipids 1980, 15(12), 10641066.

Desvergne, B.; Wahli, W. Endocr.Rev. 1999, 20(5), 649-688.

Dreesen, T. D.; Adamson, A. W.; Tekle, M.; Tang, C.; Cho, H. P.; Clarke, S. D.; Gettys, T. W. Prostaglandins Leukot.Essent.Fatty Acids 2006, 75(2), 97-106.

Dreyer, C.; Krey, G.; Keller, H.; Givel, F.; Helftenbein, G.; Wahli, W. Cell 1992, 68(5), 879-887.

Duncombe, W. G. Biochem.J. 1963, 88(1), 7-10.

Edwards, P. A.; Kast, H. R.; Anisfeld, A. M. J.Lipid Res. 2002, 43(1), 212.

Elbein, S. C. J.Nutr. 1997, 127(9), 1891S-1896S.

Enoch, H. G.; Catala, A.; Strittmatter, P. J.Biol.Chem. 1976, 251(16), 5095-5103.

Faas, F. H.; Carter, W. J. Lipids 1983, 18(4), 339-342.

Folch, J.; Lees, M.; Sloane Stanley, G. H. J.Biol.Chem. 1957, 226(1), 497-509.

Foretz, M.; Pacot, C.; Dugail, I.; Lemarchand, P.; Guichard, C.; Le, L., X; Berthelier-Lubrano, C.; Spiegelman, B.; Kim, J. B.; Ferre, P.; Foufelle, F. Mol.Cell Biol. 1999, 19(5), 3760-3768. 
Forman, B. M.; Chen, J.; Evans, R. M. Proc.Natl.Acad.Sci.U.S.A 1997, 94(9), 4312-4317.

Frederiksen, K. S.; Wulff, E. M.; Sauerberg, P.; Mogensen, J. P.; Jeppesen, L.; Fleckner, J. J.Lipid Res. 2004, 45(3), 592-601.

Gagliardino, J.J., Gómez Dumm, C.L.A., D’Ottavio, A.E., Vaves, A., y Rabasa, S.L. 1993 en: eSS Rats, an Animal Model for the Study of Spontaneous Non-Insulin Dependent Diabetes, in Lessons from Animal Diabetes IV (Shafrir, E., ed.), pp. 75-90, Smith-Gordon, London

Gellhorn, A.; Benjamin, W. Biochim.Biophys.Acta 1964, 84 167-175.

Gomez Dumm, C. L.; Semino, M. C.; Gagliardino, J. J. Pancreas 1990, 5(5), 533-539.

Guerre-Millo, M.; Rouault, C.; Poulain, P.; Andre, J.; Poitout, V.; Peters, J. M.; Gonzalez, F. J.; Fruchart, J. C.; Reach, G.; Staels, B. Diabetes 2001, 50(12), 2809-2814.

Guillou, H.; Martin, P.; Jan, S.; D'Andrea, S.; Roulet, A.; Catheline, D.; Rioux, V.; Pineau, T.; Legrand, P. Lipids 2002, 37(10), 981-989.

Guillou, H.; D'Andrea, S.; Rioux, V.; Barnouin, R.; Dalaine, S.; Pedrono, F.; Jan, S.; Legrand, P. J.Lipid Res. 2004, 45(1), 32-40.

Gutierrez-Juarez, R.; Pocai, A.; Mulas, C.; Ono, H.; Bhanot, S.; Monia, B. P.; Rossetti, L. J.Clin.Invest 2006, 116(6), 1686-1695.

Hamel, F. G.; Bennett, R. G.; Upward, J. L.; Duckworth, W. C. Endocrinology 2001, 142(6), 2702-2706.

Hannah, V. C.; Ou, J.; Luong, A.; Goldstein, J. L.; Brown, M. S. J.Biol.Chem. 2001, 276(6), 4365-4372.

Hegarty, B. D.; Bobard, A.; Hainault, I.; Ferre, P.; Bossard, P.; Foufelle, F. Proc.Natl.Acad.Sci.U.S.A 2005, 102(3), 791-796.

Heinemann, L.; Linkeschova, R.; Rave, K.; Hompesch, B.; Sedlak, M.; Heise, T. Diabetes Care 2000, 23(5), 644-649.

Henderson, R. J. Arch.Tierernahr. 1996, 49(1), 5-22.

Herbert, V.; Lau, K. S.; Gottlieb, C. W.; Bleicher, S. J. J.Clin.Endocrinol.Metab 1965, 25(10), 1375-1384.

Horton, J. D.; Goldstein, J. L.; Brown, M. S. J.Clin.Invest 2002, 109(9), $1125-1131$.

Hua, X.; Yokoyama, C.; Wu, J.; Briggs, M. R.; Brown, M. S.; Goldstein, J. L.; Wang, X. Proc.Natl.Acad.Sci.U.S.A 1993, 9O(24), 1160311607.

Hurtado de Catalfo, G. E.; de, G. D., I Int.J.Biochem.Cell Biol. 1998, 30(9), 1001-1010.

Igal, R. A.; Mandon, E. C.; de, G. D., I Mol.Cell Endocrinol. 1991, 77(13), 217-227.

Inagaki, K.; Aki, T.; Shiota, T.; Kawamoto, S.; Shigeta, S.; Suzuki, O.; Ono, K. Biosci.Biotechnol.Biochem. 2003, 67(2), 451-454.

Jiang, G.; Li, Z.; Liu, F.; Ellsworth, K.; Dallas-Yang, Q.; Wu, M.; Ronan, J.; Esau, C.; Murphy, C.; Szalkowski, D.; Bergeron, R.; Doebber, T.; Zhang, B. B. J.Clin.Invest 2005, 115(4), 1030-1038.

Jones, P. D.; Holloway, P. W.; Peluffo, R. O.; Wakil, S. J. J.Biol.Chem. 1969, 244(4), 744-754.

Jump, D. B. J.Biol.Chem. 2002, 277(11), 8755-8758. 
Kaestner, K. H.; Ntambi, J. M.; Kelly, T. J., Jr.; Lane, M. D. J.Biol.Chem. 1989, 264(25), 14755-14761.

Kawaguchi, T.; Takenoshita, M.; Kabashima, T.; Uyeda, K. Proc.Natl.Acad.Sci.U.S.A 2001, 98(24), 13710-13715.

Kawashima, Y.; Kozuka, H. Biochim.Biophys.Acta 1985, 834(1), 118123.

Kawashima, Y.; Musoh, K.; Kozuka, H. J.Biol.Chem. 1990, 265(16), 9170-9175.

Kim, H. J.; Miyazaki, M.; Ntambi, J. M. J.Lipid Res. 2002, 43(10), 17501757.

Kim, J. H.; Kim, Y.; Lee, S. D.; Lopez, I.; Arnold, R. S.; Lambeth, J. D.; Suh, P. G.; Ryu, S. H. FEBS Lett. 1999, 454(1-2), 42-46.

Kudo, N.; Toyama, T.; Mitsumoto, A.; Kawashima, Y. Lipids 2003, 38(5), 531-537.

Landau, J. M.; Sekowski, A.; Hamm, M. W. Biochim.Biophys.Acta 1997, 1345 (3), 349-357.

Leikin, A. I.; Brenner, R. R. Biochim.Biophys.Acta 1987, 922(3), 294303.

Leikin, A. I.; Brenner, R. R. Biochim.Biophys.Acta 1988, 963(2), 311319.

Levine, M.; Tjian, R. Nature 2003, 424(6945), 147-151.

Li, Y.; Nara, T. Y.; Nakamura, M. T. J.Lipid Res. 2005, 46(11), 24322440.

Liang, G.; Yang, J.; Horton, J. D.; Hammer, R. E.; Goldstein, J. L.; Brown, M. S. J.Biol.Chem. 2002, 277(11), 9520-9528.

Listenberger, L. L.; Han, X.; Lewis, S. E.; Cases, S.; Farese, R. V., Jr.; Ory, D. S.; Schaffer, J. E. Proc.Natl.Acad.Sci.U.S.A 2003, 100(6), 3077-3082.

Ljung, B.; Bamberg, K.; Dahllof, B.; Kjellstedt, A.; Oakes, N. D.; Ostling, J.; Svensson, L.; Camejo, G. J.Lipid Res. 2002, 43(11), 1855-1863.

Lombardo, Y. B.; Chicco, A.; Mocchiutti, N.; de Rodi, M. A.; Nusimovich, B.; Gutman, R. Horm.Metab Res. 1983, 15(2), 69-76.

Lombardo, Y. B.; Drago, S.; Chicco, A.; Fainstein-Day, P.; Gutman, R.; Gagliardino, J. J.; Gomez Dumm, C. L. Metabolism 1996, 45(12), 1527-1532.

Lowry, O. H.; Rosebrough, N. J.; Farr, A. L.; Randall, R. J. J.Biol.Chem. 1951, 193(1), 265-275.

Luong, A.; Hannah, V. C.; Brown, M. S.; Goldstein, J. L. J.Biol.Chem. 2000, 275(34), 26458-26466.

Man, W. C.; Miyazaki, M.; Chu, K.; Ntambi, J. M. J.Biol.Chem. 2006, 281(2), 1251-1260.

Martinez, S. M.; Tarres, M. C.; Montenegro, S.; Milo, R.; Picena, J. C.; Figueroa, N.; Rabasa, S. R. Acta Diabetol.Lat. 1988, 25(4), 303-313.

Martínez, S.M., Tarrés, M.C., Picena, J.C., Montenegro, S.M., Gagliardino, J.J., Gómez Dumm, C.L.A., D’Ottavio, A.E., Vaves,A., y Rabasa, S.L. 1993 en: eSS Rats, an Animal Model for the Study of Spontaneous Non-Insulin Dependent Diabetes, in Lessonsfrom Animal Diabetes IV (Shafrir, E., ed.), 75-90, Smith-Gordon, London 
Mater, M. K.; Thelen, A. P.; Pan, D. A.; Jump, D. B. J.Biol.Chem. 1999, 274(46), 32725-32732.

Matsuzaka, T.; Shimano, H.; Yahagi, N.; Amemiya-Kudo, M.; Yoshikawa, T.; Hasty, A. H.; Tamura, Y.; Osuga, J.; Okazaki, H.; Iizuka, Y.; Takahashi, A.; Sone, H.; Gotoda, T.; Ishibashi, S.; Yamada, N. J.Lipid Res. 2002, 43(1), 107-114.

McGarry, J. D. Diabetes 2002, 51(1), 7-18.

Mercuri, O.; Peluffo, R. O.; Brenner, R. R. Biochim.Biophys.Acta 1966, $116(2), 409-411$.

Mercuri, O.; Peluffo, R. O.; de Tomas, M. E. Biochim.Biophys.Acta 1974, 369(2), 264-268.

Mihara, K. J.Biochem.(Tokyo) 1990, 108(6), 1022-1029.

Miller, C. W.; Ntambi, J. M. Proc.Natl.Acad.Sci.U.S.A 1996, 93(18), 9443-9448.

Miyazaki, M.; Kim, Y. C.; Gray-Keller, M. P.; Attie, A. D.; Ntambi, J. M. J.Biol.Chem. 2000, 275(39), 30132-30138.

Miyazaki, M.; Man, W. C.; Ntambi, J. M. J.Nutr. 2001, 131(9), 22602268.

Miyazaki, M.; Gomez, F. E.; Ntambi, J. M. J.Lipid Res. 2002, 43(12), $2146-2154$.

Miyazaki, M.; Ntambi, J. M. Prostaglandins Leukot.Essent.Fatty Acids 2003, 68(2), 113-121.

Miyazaki, M.; Jacobson, M. J.; Man, W. C.; Cohen, P.; Asilmaz, E.; Friedman, J. M.; Ntambi, J. M. J.Biol.Chem. 2003, 278(36), 3390433911.

Miyazaki, M.; Dobrzyn, A.; Elias, P. M.; Ntambi, J. M. Proc.Natl.Acad.Sci.U.S.A 2005, 102(35), 12501-12506.

Mourente, G.; Tocher, D. R. Biochim.Biophys.Acta 1994, 1212(1), 109118.

Mouritsen, O. G.; Jorgensen, K. Bioessays 1992, 14(2), 129-136.

Mziaut, H.; Korza, G.; Ozols, J. Proc.Natl.Acad.Sci.U.S.A 2000, 97(16), 8883-8888.

Nagai, Y.; Nishio, Y.; Nakamura, T.; Maegawa, H.; Kikkawa, R.; Kashiwagi, A. Am.J.Physiol Endocrinol.Metab 2002, 282(5), E1180E1190.

Nakamura, M. T.; Nara, T. Y. Prostaglandins Leukot.Essent.Fatty Acids 2003, 68(2), 145-150.

Nakamura, M. T.; Nara, T. Y. Annu.Rev.Nutr. 2004, 24 345-376.

Napier, J. A.; Michaelson, L. V.; Sayanova, O. Prostaglandins Leukot.Essent.Fatty Acids 2003, 68(2), 135-143.

Ntambi, J. M.; Buhrow, S. A.; Kaestner, K. H.; Christy, R. J.; Sibley, E.; Kelly, T. J., Jr.; Lane, M. D. J.Biol.Chem. 1988, 263(33), 1729117300.

Ntambi, J. M. Prog.Lipid Res. 1995, 34(2), 139-150.

Ntambi, J. M.; Miyazaki, M. Prog.Lipid Res. 2004, 43(2), 91-104.

Parthasarathy, S.; Khoo, J. C.; Miller, E.; Barnett, J.; Witztum, J. L.; Steinberg, D. Proc.Natl.Acad.Sci.U.S.A 1990, 87(10), 3894-3898.

Peet, D. J.; Turley, S. D.; Ma, W.; Janowski, B. A.; Lobaccaro, J. M.; Hammer, R. E.; Mangelsdorf, D. J. Cell 1998, 93(5), 693-704. 
Pereira, S. L.; Leonard, A. E.; Mukerji, P. Prostaglandins Leukot.Essent.Fatty Acids 2003, 68(2), 97-106.

Rahman, S. M.; Dobrzyn, A.; Dobrzyn, P.; Lee, S. H.; Miyazaki, M.;

Ntambi, J. M. Proc.Natl.Acad.Sci.U.S.A 2003, 100(19), $11110-$ 11115.

Reaven, G. Endocrinol.Metab Clin.North Am. 2004, 33(2), 283-303.

Reaven, G. M. Annu.Rev.Nutr. 2005, 25 391-406.

Reddy, J. K.; Hashimoto, T. Annu.Rev.Nutr. 2001, 21 193-230.

Repa, J. J.; Liang, G.; Ou, J.; Bashmakov, Y.; Lobaccaro, J. M.; Shimomura, I.; Shan, B.; Brown, M. S.; Goldstein, J. L.; Mangelsdorf, D. J. Genes Dev. 2000, 14(22), 2819-2830.

Repa, J. J.; Mangelsdorf, D. J. Nat.Med. 2002, 8(11), 1243-1248.

Rimoldi, O. J.; Finarelli, G. S.; Brenner, R. R. Biochem.Biophys.Res.Commun. 2001, 283(2), 323-326.

Rivers, J. P.; Sinclair, A. J.; Craqford, M. A. Nature 1975, 258(5531), 171-173.

Sambrook, J., Fritsch, E.F. y Maniatis. T. 1989 en: Molecular cloning, A laboratory manual. Cold Spring Harbor Laboratory Press. 9.389.57.

Sampath, H.; Ntambi, J. M. Annu.Rev.Nutr. 2005, 25 317-340.

Sampath, H.; Ntambi, J. M. Curr.Opin.Clin.Nutr.Metab Care 2006, 9(2), 84-88.

Schoonjans, K.; Staels, B.; Auwerx, J. J.Lipid Res. 1996, 37(5), 907925.

Schultz, J. R.; Tu, H.; Luk, A.; Repa, J. J.; Medina, J. C.; Li, L.; Schwendner, S.; Wang, S.; Thoolen, M.; Mangelsdorf, D. J.; Lustig, K. D.; Shan, B. Genes Dev. 2000, 14(22), 2831-2838.

Shimomura, I.; Shimano, H.; Horton, J. D.; Goldstein, J. L.; Brown, M. S. J.Clin.Invest 1997, 99(5), 838-845.

Shimomura, I.; Matsuda, M.; Hammer, R. E.; Bashmakov, Y.; Brown, M. S.; Goldstein, J. L. Mol. Cell 2000, 6(1), 77-86.

Shulman, G. I. J.Clin.Invest 2000, 106(2), 171-176.

Small, G. M.; Burdett, K.; Connock, M. J. Biochem.J. 1985, 227(1), 205210.

Song, H. W.; Nara, T. Y.; Nakamura, M. T. Biochem.Biophys.Res. Commun. 2002, 299(5), 832-838.

Soria, A.; D'Alessandro, M. E.; Lombardo, Y. B. J.Appl.Physiol 2001, 91(5), 2109-2116.

Sperling, P.; Linscheid, M.; Stocker, S.; Muhlbach, H. P.; Heinz, E. J.Biol.Chem. 1993, 268(36), 26935-26940.

Sperling, P.; Ternes, P.; Zank, T. K.; Heinz, E. Prostaglandins Leukot.Essent.Fatty Acids 2003, 68(2), 73-95.

Sprecher, H. Prog.Lipid Res. 1981, 20 13-22.

Sprecher, H.; Luthria, D. L.; Mohammed, B. S.; Baykousheva, S. P. J.Lipid Res. 1995, 36(12), 2471-2477.

Stammberger, I.; Bube, A.; Durchfeld-Meyer, B.; Donaubauer, H.; Troschau, G. Int J Toxicol. 2002 21(3), 171-9.

Stukey, J. E.; McDonough, V. M.; Martin, C. E. J.Biol.Chem. 1990, 265(33), 20144-20149. 
Sugden, M. C.; Holness, M. J. Diabetes 2004, 53 Suppl 1 S71-S81.

Sun, Y.; Hao, M.; Luo, Y.; Liang, C. P.; Silver, D. L.; Cheng, C.; Maxfield, F. R.; Tall, A. R. J.Biol.Chem. 2003, 278(8), 5813-5820.

Tang, C.; Cho, H. P.; Nakamura, M. T.; Clarke, S. D. J.Lipid Res. 2003, 44(4), 686-695.

Tiku, P. E.; Gracey, A. Y.; Macartney, A. I.; Beynon, R. J.; Cossins, A. R. Science 1996, 271(5250), 815-818.

Tobey, T. A.; Mondon, C. E.; Zavaroni, I.; Reaven, G. M. Metabolism 1982, 31(6), 608-612.

Tordjman, K.; Bernal-Mizrachi, C.; Zemany, L.; Weng, S.; Feng, C.; Zhang, F.; Leone, T. C.; Coleman, T.; Kelly, D. P.; Semenkovich, C. F. J.Clin.Invest 2001, 107(8), 1025-1034.

Tricerri, M. A.; Garda, H. A.; Brenner, R. R. Chem.Phys.Lipids 1994, $71(1), 61-72$.

Tugwood, J. D.; Issemann, I.; Anderson, R. G.; Bundell, K. R.; McPheat, W. L.; Green, S. EMBO J. 1992, $11(2), 433-439$.

Voss, A.; Reinhart, M.; Sankarappa, S.; Sprecher, H. J.Biol.Chem. 1991, 266(30), 19995-20000.

Wang, J.; Yu, L.; Schmidt, R. E.; Su, C.; Huang, X.; Gould, K.; Cao, G. Biochem.Biophys.Res.Commun. 2005, 332(3), 735-742.

Wang, Y.; Kurdi-Haidar, B.; Oram, J. F. J.Lipid Res. 2004, 45(5), 972980.

Wang, Y.; Botolin, D.; Xu, J.; Christian, B.; Mitchell, E.; Jayaprakasam, B.; Nair, M. G.; Peters, J. M.; Busik, J. V.; Olson, L. K.; Jump, D. B. J.Lipid Res. 2006, 47(9), 2028-2041.

Waters, K. M.; Ntambi, J. M. J.Biol.Chem. 1994, 269(44), 27773-27777.

Wolfrum, C.; Borrmann, C. M.; Borchers, T.; Spener, F. Proc.Natl.Acad.Sci.U.S.A 2001, 98(5), 2323-2328.

Xu, J.; Nakamura, M. T.; Cho, H. P.; Clarke, S. D. J.Biol.Chem. 1999, 274(33), 23577-23583.

Xu, J.; Teran-Garcia, M.; Park, J. H.; Nakamura, M. T.; Clarke, S. D. J.Biol.Chem. 2001, 276(13), 9800-9807.

Xu, J.; Cho, H.; O'Malley, S.; Park, J. H.; Clarke, S. D. J.Nutr. 2002, 132(11), 3333-3339.

Yamashita, H.; Takenoshita, M.; Sakurai, M.; Bruick, R. K.; Henzel, W. J.; Shillinglaw, W.; Arnot, D.; Uyeda, K. Proc.Natl.Acad.Sci.U.S.A 2001, 98(16), 9116-9121.

Zhang, L.; Ge, L.; Parimoo, S.; Stenn, K.; Prouty, S. M. Biochem.J. 1999, 340 ( Pt 1) 255-264.

Zheng, Y.; Prouty, S. M.; Harmon, A.; Sundberg, J. P.; Stenn, K. S.; Parimoo, S. Genomics 2001, 71(2), 182-191.

Zhou, Y. T.; Shimabukuro, M.; Wang, M. Y.; Lee, Y.; Higa, M.; Milburn, J. L.; Newgard, C. B.; Unger, R. H. Proc.Natl.Acad.Sci.U.S.A 1998, 95(15), 8898-8903.

Zolfaghari, R.; Cifelli, C. J.; Banta, M. D.; Ross, A. C. Arch.Biochem.Biophys. 2001, 391(1), 8-15.

Zolfaghari, R.; Ross, A. C. Prostaglandins Leukot.Essent.Fatty Acids 2003, 68(2), 171-179. 